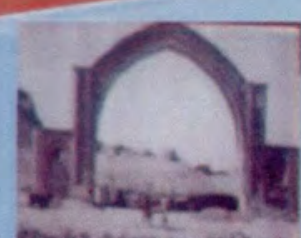
mester

\section{بلستأشناسى افغلانستان

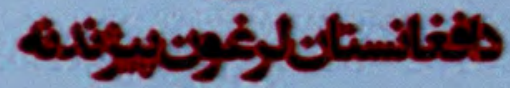

a) $x+4$

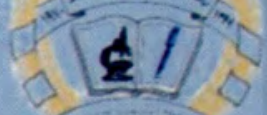

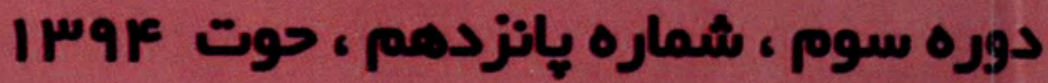

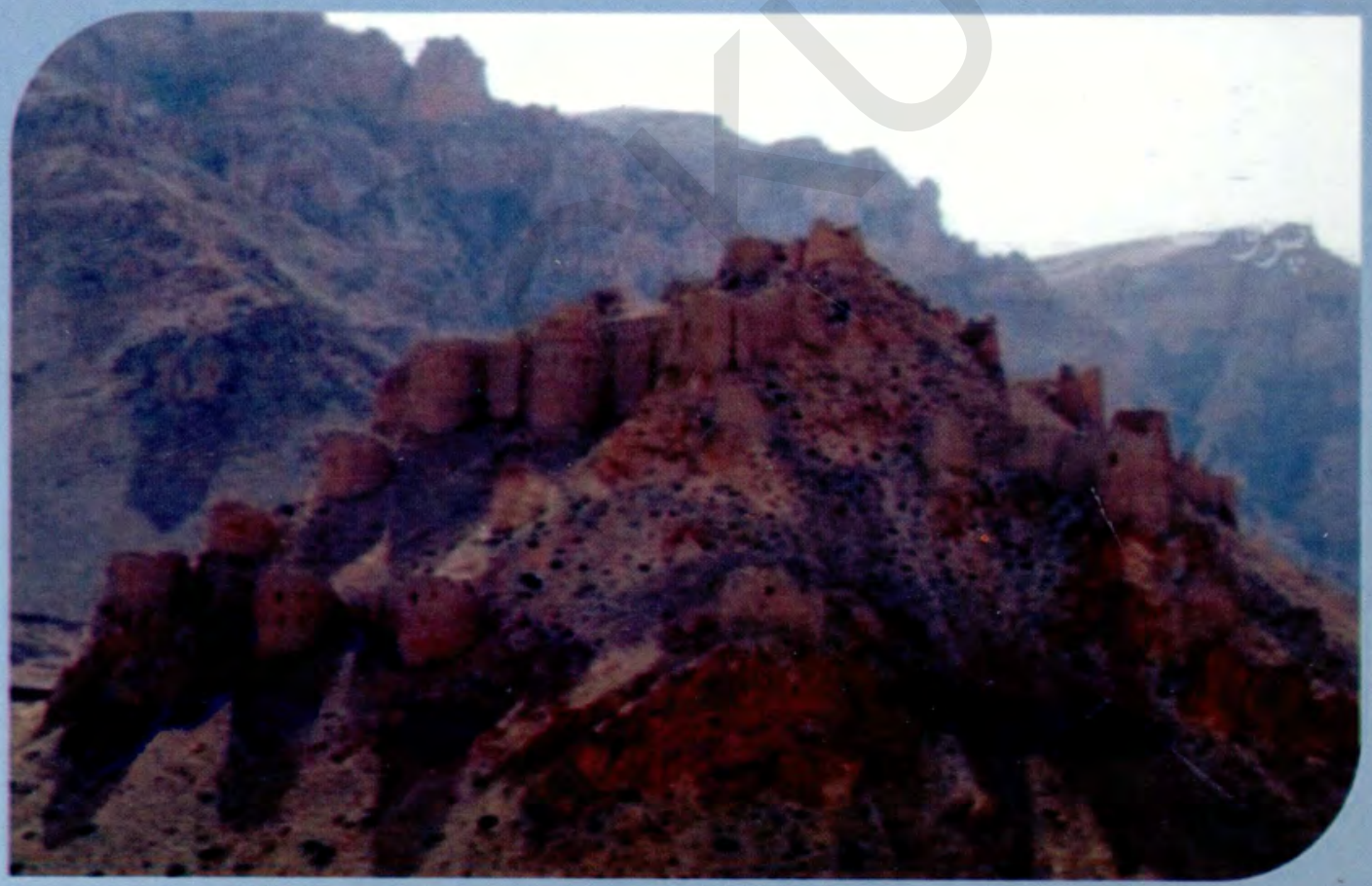




\section{مجله باستانشناسى افغانستان

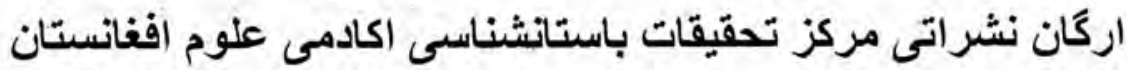

دوره سوم ش شماره بانزدهم حوت

\section{فهرست مطالب}

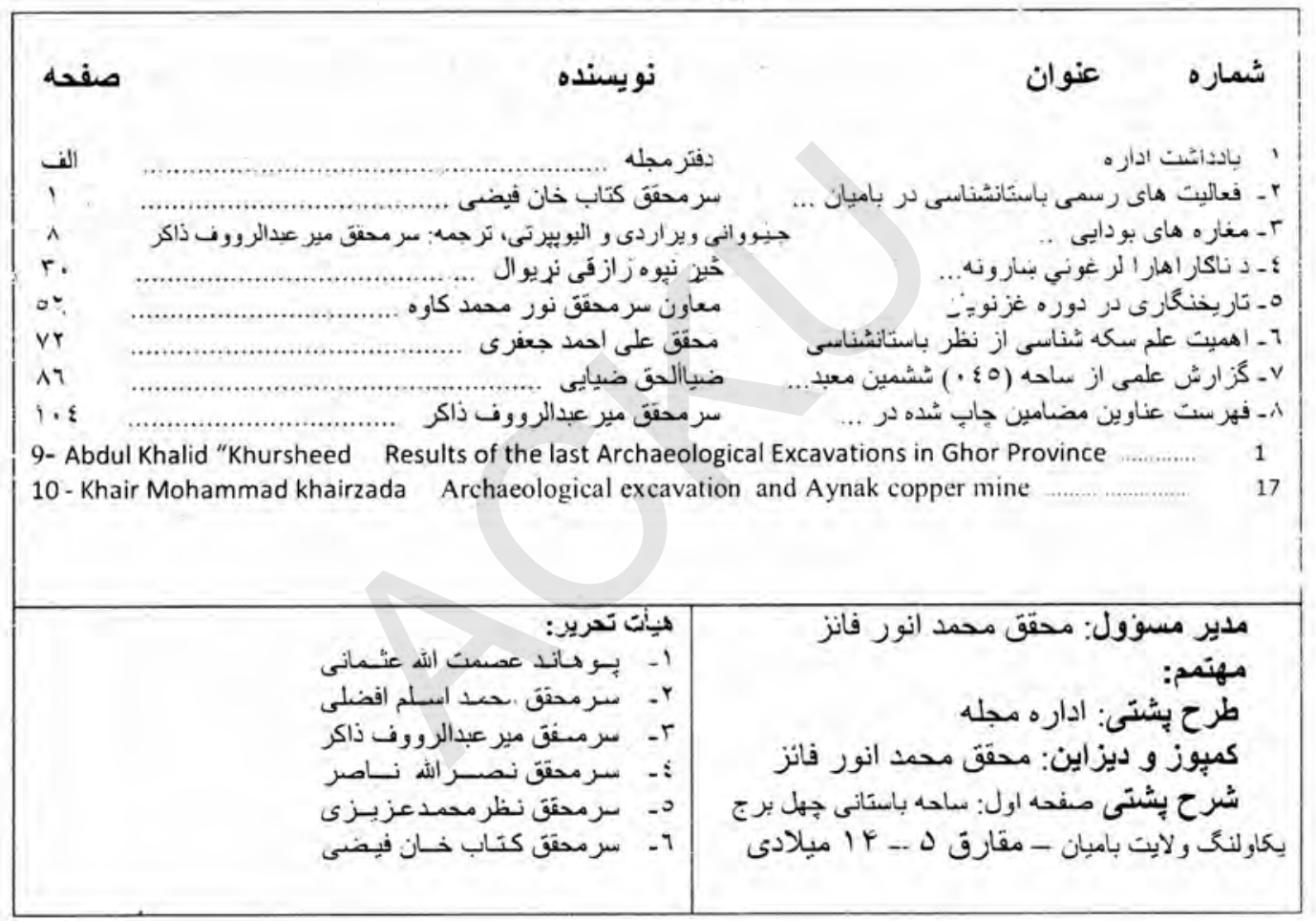




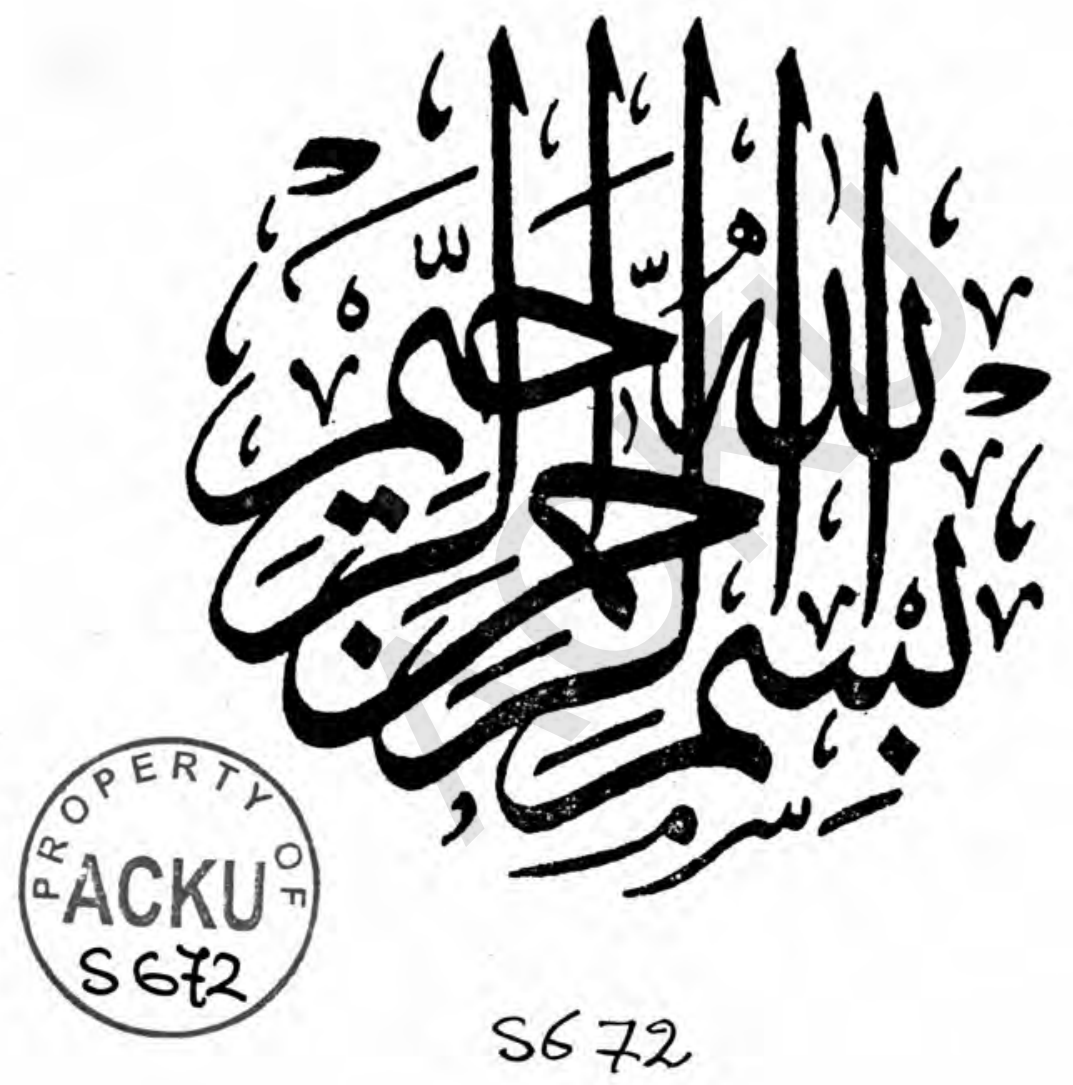




\section{يادداشت اداره}

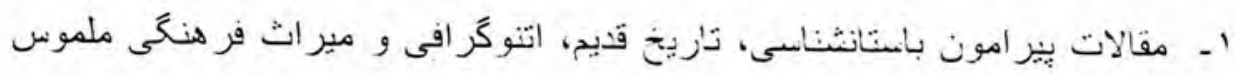

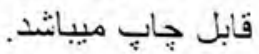

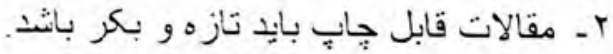

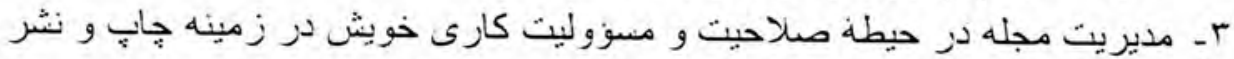

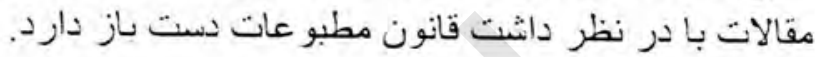

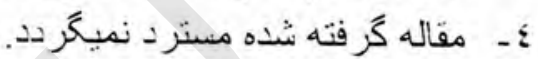

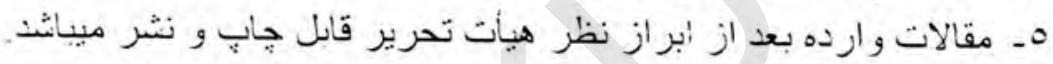

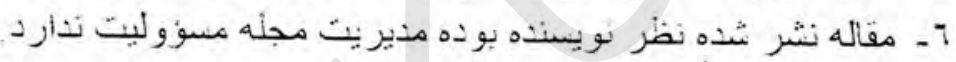

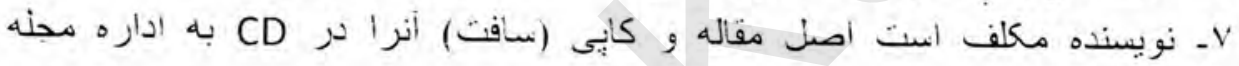
هـ نو بيسنده كان مقالات بايد انم، ابمل آدرس و نمبر تيلفون خويش را به

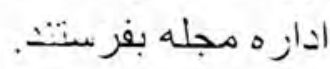


فعاليت ماى رسمى باستانشناسى در باميان قبل از سال .... ميلادى

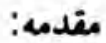

كشور عزيز ما افغانستان با قدامت و يشينة تاريخى خويش آثار گرانبهاى تاريخى و فرهنگى را در خود حفظ نموده است. مردم اين خطه باستانى از آوان ييدايش در مغاره ماى سرباز و سر يوشيده امرار حيات نموده اند، كه بقاياى اين مغاره ما در نقاط مختلف و در هرگوشه و كنار مملكت تا كنون موجود ميباشد.كه طور مثال ميتوا ن از مغاره هاى باميان نام

باميان يكى از ولايات مركزى افغانستان بوده كه فاصلة آن از كابل كيلومتر و ارتفاع

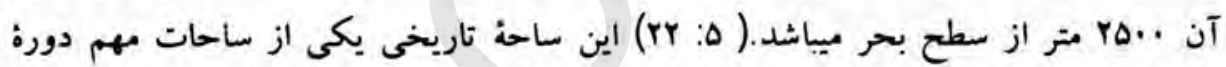
بودايى است كه تاريخ آن از قرن دوم ميلادى آغاز گرديده و كشفيات جديد باستانشناسى در

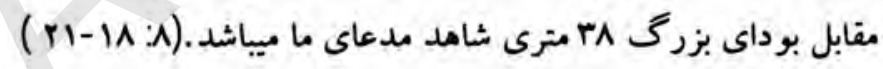
ساحه باستانى باميان داراى آبدات تاريخى و آثار منحصر به فرد بوده كه توجه جهانيان و جهانكردان را بخود جلب و مجسعه شاى عظيم ها مترى و rA مترى به ارزش مادى و معنوى

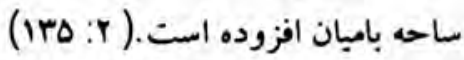
سياحين جينايى و ارويايى در طى قرون هفتم، هثتم و نزدهم ميلادى از باميان بازديد نموده و يادداشت ماى را از خويش به جا مانده اند و اما سروى هاى رسمى باستانشناسى براى اولين بار تحت سريرستى الفرد فوشه (Alfred Foucher) رئيس تيم دافا در افغانستان آغاز 1 باستانشناسى افغانستان 
گرديد و گزارش مفصلى را به رئيس انجمن آسيايى (Societe Asiatique de Paris) در خاريس ارايه داشته و در آن ساحات باميان را با ارزش معرفى نمود كه بكك صفحه جذيدى را در تاريخ باميان گتود. بعدأ در همان سال مرحلة تحقيقات ساختمانى مهندسى توسط اندارا كودار (Godard Ander) و همسرش بدا (Yedda) و به همكارى آقاى جوزف هاكن در باميان به مرحله اجرا در آمد و نتايج تحقيقات آنها در سال 19r^ ميلادى به نشر رسبد كه از همان تاريخ به بعد باميان بر ايى مردم افغانستان و جهان شهرت به سزاى دريافت نمود. (IV F )

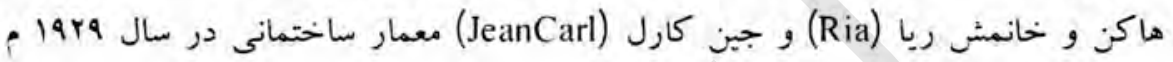
دوباره از افغانستان ديدن نمودند و دست آورد هاى مهمى را در مورد نقوش ديوارى باميان و ككركت صيب شذند و همجنين أولين حفريات را در مغاره G در شرق بوداى هذ منرى أنجام داد كه در نتيجه از روى نقوش ديوارى و بارجه هائ كتيبه ها برده برداشته شد. از حفريات متذكره مواد مهمى براى تحقيفات در مورد بأميان به دسك آمد كه نتايج مكمل آن در سال (Nouvelles Researches Archaeologiques a Bamyan) به نشر 199 م تحت رسبد.) (19) در سال .rاه مج جوزف هاكن سروى بيشترى را به منظور افزايش دانش تحقبقات گذشته به مرحلة أجرا در آورد در طول اين سروى جين كارل فرانسوى عضو هيأت (DAFA) حفرياتى را در مغاره GOI انجام داد كه به اثر آذ بارجه هاى نقوش ديوارى، مجسمه هاى

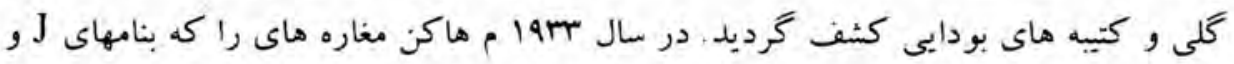

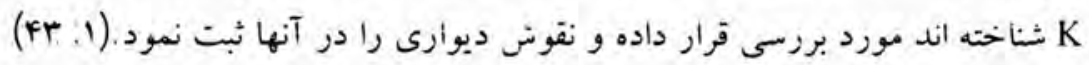


هيأت اعزامى باستـان شناسى به همكارى ستروين (Citroen) در سـال 19rr م وارد باميان در همين سان نأزيخ شناس هنر جايانى سيوسوك اوداكا (SennoosukeOdaka) انستيتوت تحفبقاتى هثر توكيو كه بعداً ابن انسنيوت به نام (انستينوت تحقيقاتى ملى براى داشته

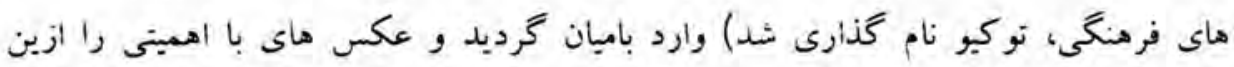

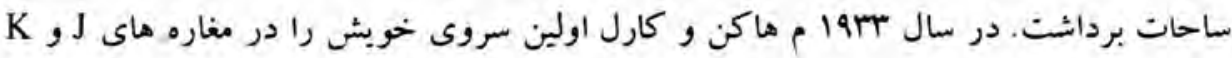

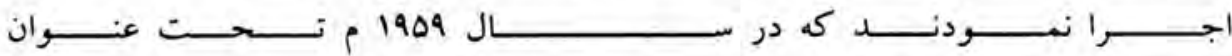
(Diverses Research archelogiques en Afghanistan)

دانشمندان ابتالوى از بوهنتون هاروارد به رهبرى بنجامين رولند (Benjamin Roland)در سال و4ها م تحقيقات خويش را در باميان انجام داد و نشريه اي تحت عنوان نقوش ديوارى

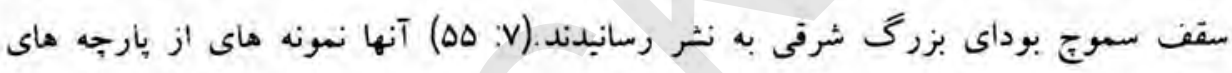

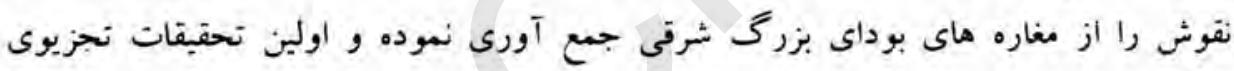

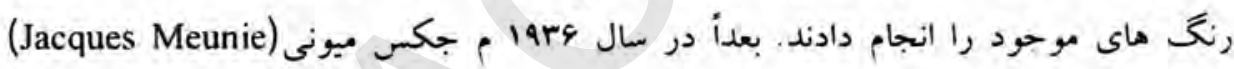
نقشه باميان را تكميل نمود. ريا هاكي (Ria Hackin) با همكارى استاد احمدعلى كهزاد نماينده موزيم ملى افغانستان حر اوايز سال 19 ام داستان هاى سنتى مردم باميان و جا هاى مقدس را به شمول شهر غلغله

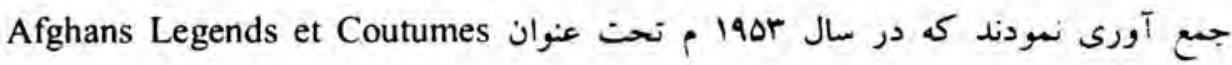

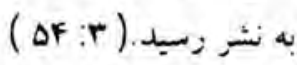
در سال rه 19 م دروازه هاى باستان شناسى در سطع بين المللى در افغاتستان گشوده شد ور بأستانشناسى اففانستان 
مطالعات تازه در مورد باميان صورت گرفيث. در سالهاى 1994 و 1999 م يكك تيم جايانى از

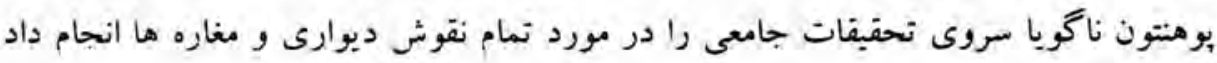
در سال 19Vr م تيم ديخر جابانى از يوهنتون توكيو سروى عكاسى مكملى را به بايان

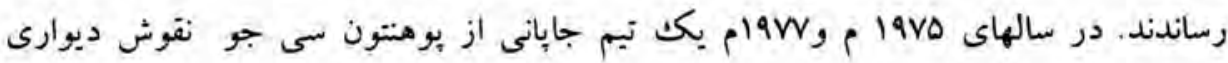

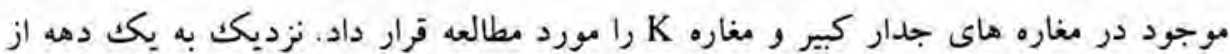
سال 1999 م تا l9VA م سروى باستانشناسى هندوستان با حمايث يونسكو برنامه ترميم و وقابه

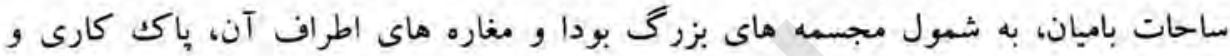
استحكام نقوش ديوارى آنها و ساير كار ها را انجام دادند و در فرجام كار هاى تحقيقاتى بر بـ زمريالى طرزى در مورد باميان و انستيتوت باستانشناسى افغان و دبراه كلمبرى سالتر

( IV:Deborah Klimburg-Salter هبجنان الفرد فوشه در سال هاى (IAFV،IAFD،IAFF،IAFY) در مورد شناسايى شهر قديم تذكر داده است كه شهر قديم باميان برخلاف آنقدر وسعت نداشته است كه نظريه آن برخلاف نظريات زاير جينايى شوان زان' و M.L.CARTER كه در سال هA19 ارابه نموده.

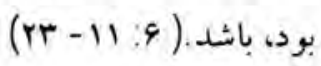

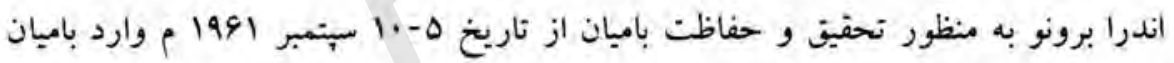

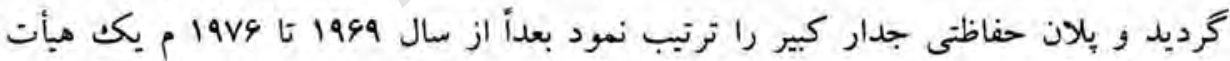
افغان و هند به رهبرى موسسه سروى باستانشناسى هندوستان (ASI) به حمايت يونسكو تحت

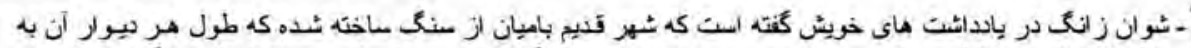

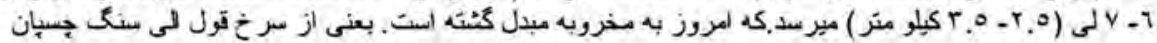


سريرستى سنكويتا صورت گرفت كه اين هيأت كار ترميمأثى را در روى مجسمه هاى بزرك بودا، سموج ها و نقوش ديوارى انجام شد كه در برخى كار هاى ترميماتى از قبيل، ترتيب و تنظيم ديوار استنادى در مطابقت با شكل صخره ها، ير كارى درز هاى بزرگ صنخره با سمنت ساختن سيستم زهكثى آب بر روى سنگ بالاى سموج دو بودا و ترميه زينه ها را نيز انجام دادند. سيس يروفيسور اكيرا مياجى (Akira Miyaji) و كوزاكو ميده (Kosaku Meada) در

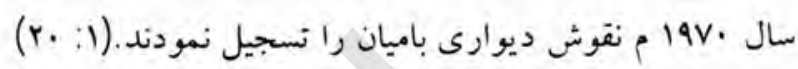
تمام اين سروى ها و گزارشات علمى، اطلاعات حيرت انگيز جديدى بر تحفيقات اوليه دافا افزود و بنيان علمى مستحكمى براى تحقيقات بيشتر در مورد باميان را هايه كذارى نمود. با تأسف فراوان زمانيكه اين همه كار ها به منصه اجرا قرار كرفت بكار ديخر غبار جنگ بر فضاى باميان طنين افكُد و آثار باستانى افغانستان غارت شد. در سال I99F م، نانسى هج دويرى از جمله اولين كسانى بود كه متوجه وضعيت بحرانى أشته هاى فرهنَ افغانستان كرديده و انجمن حفظ ميراثهاى فرهنگى افغانستان SPACH در اسلام آباد باكستان تأسيس نمود و خدمات شايانى در عرصه ميراث هاى فرهنگ افغانستان و به خصوص باميان انجام داد و آنجه در توان داشت در جهت آكاهى مردم براى جلو گيرى

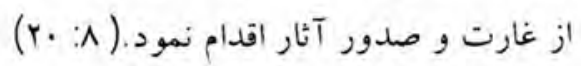

$$
\text { نتيجه: }
$$

باميان در مركز راه تجارتى شرق و غربت فرار داشته و بكى از شاخه هاى مهم راه ابريشم به شمار ميرود. نظر به تحفيقات تازة كه در همين اواخر صورت كرفته، فدامت تاريخى باميان به 
قرن دوم ميلادى ميرسد و همجنان در قرن سوم و جهارم و حتى تا قرن هفتم ميلادى به نقطة اوج خويش رسيده بود، كه متأسفانه در قرون بعدى به خصوص در زمان لشكركشى جنگيز خسارات زيادى را متقبل شده و بعد ها در قرن ·r مورد توجه جهانيان به خصوص تيم هاى باستانشناسى كشور هاى فرانسه، ايتالبا، جرمنى، جايان و هندوستان قرار گرفت كه آنها ساحات باميان را حفريات، مجسمه هاى بزرگ بودايى، مغاره ها و نقوش ديوارى را وقايه و ترميم نمودند و تا زمانى به حالت خوبى قرار داشت كه سياحين و جهانغردان از آن ساحه بازديد بردي مى نمودند و از لحاظ اقتصادى براى كثور ما عايدى به دست مى آمد. متأسفانه در فبرورى |..l بيكره هاى بودايى با نقوش ديوارى و مغاره هاى اين ساحه

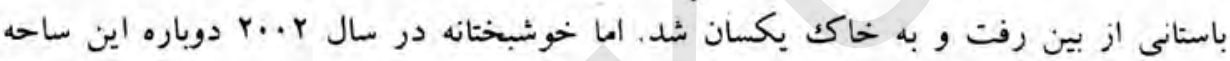
مورد توجه جهانيان قرار گرفت كه كشور هاى ذبعلاقه در ساحات مختلف باميان تحقيقات باستانشناسى و ترميماتى را آغاز كردند و باميان توانست كه به يكك ساحه توريستيكى و جهانگردى مبدل گردي

\section{بششنهادات}

ا- از مقام محترم وزارت اطلاعات و فرهنگ تقاضا ميگردد تادر حصه باز سازى و ترميم ساحه باستانى باميان توجه جدى رأروبدست كيرند.

r- از مقام محترم اكادمى علوم افغانستان تقاضا به عمل مى بآيد تا يكث ديهارتمنت باميان شناسى را در جو كات مركز باستانشناسى اكادمى علوم ايجاد نمايد. 


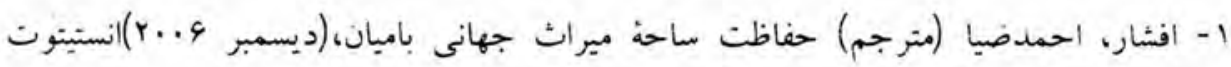
نحقيقاتى ملى و داشته هاى فرهنىى، جايان.

r- فيضى،كتابخان لعصر شكُفايى باميانه باميان در دو سده اخير، جلد دوم، مطبعة اكبر، كابل: :

r- كمال، زمرى (اعظمت باميان در جهره بيكره هاى آنه مجله باستانشناسى، شماره اول

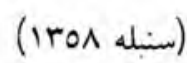

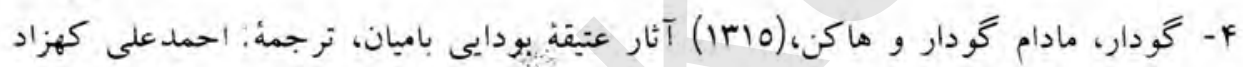
انجمن ادبى كابل، مطبعة عمومى، كابل. ه- كهزاد، احمدعلى، (1F4) افغانستان در يرتو تاريخ، كابل، مطبعه دولتى.

\section{Bibliography:}

- 6-Bamiyan (2006)The Fifth Excavation Campaign of Prof. Tarzi Mission, Silk Road Review, and Newyark.

7. Protecting the world heritage site of Bamiyan, Japan 2004.

8- Roland, B, 1938.The Wall-Painting of India, Centeral Asia and Seylon, Bostan: Eastern Book Linkers. 
نويسـنده گان: جـيـوروانى ويراردى و اليويرتي بركردان به درى: سرمحقق ميرعبدالرووف ذاكري ورئي

مغاره هاى بودايى جاغورى و قره باغ غزنى افغانستان

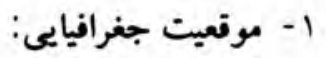

مغاره هاى بودايى ييكه در قسمت شمال غربى ولسوالى قره باغ و قسمت شمال شرفى ولسوالى جاغورى ولايت غزنى موقعبت دارد و درين گزارش تشريح گرديده باهم ارتباط دارند.(شكل 1-r) ساحه ياد شده از جنوب توسط بخشى از سركك جاغورى - قره باغ در بين غوجور بطرف شمال شرق جاغورى و بازار زردآلو 9r، كيلومترى غرب راه بركشت از قره باغ بالاى شاهراه غزنى- مقر و از طرف شمال به ساختمانهاى بزرى و زمين هاى باير و از جنوب به جهيل ناور محاط ميباشد.

دو عدد ازين ساخت و ساز هاى بزرق در كوه رس داراى ارتفاع بهم متر وكوه دهبادى

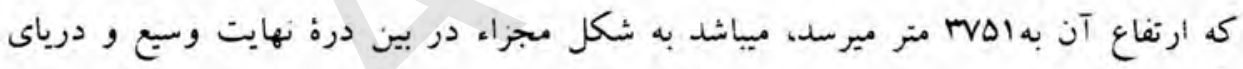
ارغنداب كه جندين رود فرعى را در نزديك منابعى كه مستفيماً به جنوب غرب جريان داشته از طريق درياى غزنى كه همجنان جندين رود فرعى را كه از كوه هاى شرق و جنوب به جهيل ناور ميريزند، به خود آميخته است. درياى غزنى كه در جهيل آب ايستاده جنوب مقر جريان دارد از شمال غزنى منشاء گُرقه است. جند تشكل واقع كه در ساحه مشهود ميباشد ماند سطح كوه گوارا بطرف جنوب شرف كوه دهبادى كه از نوكى كوه خود Koh-e- Khud 
(محلات كه AIXVIII.LXXVI.LXXIX.a) جناح راست تاينا تنگى Tayna Tangi و نواى خديداد Nawa-ye- Khodaydad قرار دارد.كو. خود Khud علامه روشن و قابل ديد براى تمام رهنما ها ميباشد.

Chub Maskha ساختمانهاى بزرگ قريه جوب مسخاه Zardalu دور نبوده از درياى ترنك مبدأ گرفته و به سبب جريان كوتاه به طرف جنوب قبل از جريان موازى بطرف جنوب غربى ارغنداب ادامه دارد. ما موفق به مشاهدة اين ساحه كه به سمت جنوب سرك غوجور Ghujur و بازار زردآلو واقع شده، نشديم.

رود هاى فرعى درياى غزنى و ارغنداب در دره هاى طويل و كم عرض بالا كه در اثر احتكالات انشعابى را در ساختمانها وارد آورده بسيار نزديك در كنار ساحل جنوب جهيل ناور رسيده و همجنان گذر گاه طبيعى براى مسافرينيكه از خيائين جشمه آمده اند و ميخواهند عبور نمايند، ميباشد. بعضى از دريا ها و رود (درياها)، تنگاى و, تنگى(river gorges)درياى تنغى)

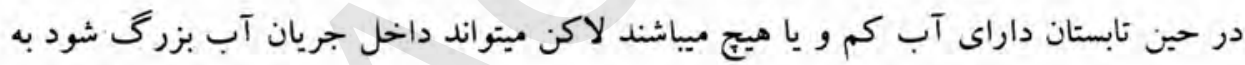
همين فسم حتى مشاهدة سرعت آب جهره ساحه را به خوبى نشان ميدهد. دره (دره ها) و ناوه (ساحات را توسط آب موجوده حاصل خيز ميسازد) نيز دفعتاً سيلابى ميسازد.

منطقه ميتواند از راه دور جنوب غرب معبر ارغنداب و ترنك را تعقيب نمايد. در سال 19V9 ام ما كاروانى از كوجيهاى قوم سنوار Sinuar (ممكن سهنوار مقايسه ادامس •191 : FIA) را در امتداد درياى جلدكث (جاييكه ساختمانهاى بزرگ ناى قلعه Nay Qala شروع شده) به غرب كوه دهبادى Dehbaday و در نتيجه از طريق درياى غزنى كه راه آنها به كندهار ميباشد 
ملاقات كرديم. راه از منطقه آب ايستاده(از دره زوب بلوجستان و بنجاب بيشتر دور ميباشد)كه

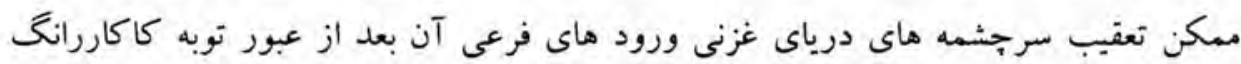
Toba Kakar Range

منطقه كمى شناخته شده بود و ما به فقدان معدن شناس و جيومورفولوجيكل(شخصى كه علم برجستحى هاى سطح زمين و علل بيدايش آنرا ميداند) در تشريح آن منطقه مواجه بوديم. يستى هاى ساختمانهاى آتشفشانى به شمال دشت ناور كم توسط بوردت Bordet در سال

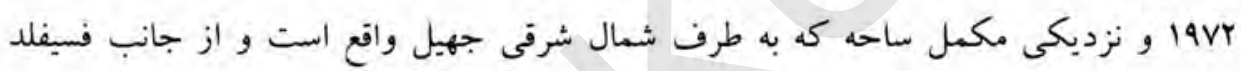
Fesefeldt

تنوع بخشيدن عمده دورنمايى طبقات الارضى حتى در داخل يكك ساحه آكاهى محدودى را برخلاف نتيجه عمومى ميدهد. به هرحال موجوديت سنخ آتشفشان دورة سوم در تحت زمين يكت جا با صخره هاى عصر بليوزوييك و تشكل رسوبات عصر بليوجنيك Paleogenic كه احتمالأ در ساحه است، ذيلاً مطالعه ميشود: درك حجره هاى آتشفشانى تهدابى بليوزويبك (دوران اول) به شكل نسبتى كه جديداً صورت گرفته به (4ه-r، ه مليون سال) ميرسد، بدون تشخيص ميباشد.

ساحه ييكه بين غزنى و ولايات بِكتيا و بكتيكا موجود و شناخته شده است از شتزارهاى بى كيفيتى تشكيل شده ماند شاهى قالو Shahiqalu و شاليز Shales كه آنها از جندين جا به واسطه آبرو هاى زمين از هم جدا و منتج به بى استحكامى، فروريختن و مانع شورخوردن بصوزت عمومى شده اند. در آنجا نيز سنگهاى آهك در بين طبقات شنزار افزايش يافته، درين باستانشناسى افغانستان 
مغاره هاى بودايى جاغورى و قره باغ غزنى افغانستان

مرحله در بين يكك تعداد مغاره ها تجزيه و تشكيل شده است. ممكن تشكل مغاره ها همجنان در بين شنزار و, آب برده گى انتخاب شده باشد. معمولاً سقف به طبقات سخت طولأ امتداد يافته و در وقت كار يكك حفره از ساييده گیى و جاى نرمى نتيجه گرفته ميشود. اكثر مغاره هاى ساحه براى ما مصنوعى معلوم ميشد كه احتمال' توسط بزرگ ساختن حفره هاى خورد و طبيىى ايجاد شده نه با قرار دادن كار معين بى عيب منحصر به فرد در صخره. اين تشريحات ممكن كم از كم شامل حال وسعت و بهناى ساحه جاغورى و قره باغ بوده اگر جه در قسمت جدايى ساحه مرتكب اشتباه شده ايم و بازديديكه در سمت شرقى ساحه صورت گرفت سنخ هاى تشكيل شده مطابقت با دو طرف نداشت. شتزارها معمولاً نمونه عكس مناظر طبيعى بخش فوقانى شمال سرك زردآلو - غوجور و مغاره هاى بودايى را كه در آن كاوش صورت گرفته تشكيل داده است

كناره هاى ديوار هاى سنخى بعضى مغاره ها مانند Nay Qala ناى قلعه، گور گين Gawargin، كوه ال Koh-e-El و بايكك Bayak هموار و راست بوده و ده متر ارتفاع دارد (محلات: III.XLIV.LXXVII.a.b همراه شكستكى خاص سطح شنزار جديداً ايجاد شده باشد. انطباق و قرار دادن تاقجه هاى طولى و بيضوى در يكك خط بالاى ديوار هاى سنگى ميتواند مثال خوبى براى اظهار عقيده زود در هماى قلعه باشد..(محل:XX) اينها شايد سنگ هاى آهك باشندكه توسط افزايش سايده گى ها در داخل يكك سلسله ريكها محو شده باشند. در ساختار هاى بزرگ ناى قلعه مشاهده نموديم كه موانع سنگ همراه با سطح ناهموار و شكسته در داخل احتمالأ درز ها با جند تكه 


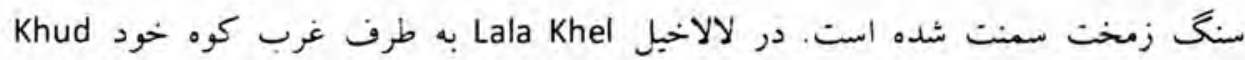
(محل: (LXXIX.b) زمين متناوبى توسط زمين شناسان تشخيص داده شده كه هركدام آنها با مر تبه ساييده گى ها برابر ميباشد. شتزار ها در بالاى سنگهاى دشتى در كنار دريا و نشيبى تشكيل

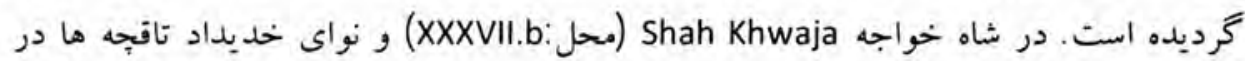
زمين هاى انحناء داده شده و سقف طبقه سنگى در بين بعضى مغاره هاى خاص تشكيل شده شنزار به ملاحظه ميرسد در بعضى حالات ساختمانهاى رسوبى به شكل تاقهاى كنده شده معلوم ميشود و در آنجا همجنان يكنوع عقيق در بين سنگ ريخى و درشت بوده است تمونه سايش حفيقى را نمينوان بدون سروى ويثه دقيفاً معين نمود زيرا هر يكى آنها توسط باد (با آب و هواى خاص محلى روزانه) با تعامل كيمياوى، گرد، سير نور، انواع نمكيات لازم قابل اطمينان با توسط فاعلين مرحله نخست گونه گون، جريانات آب و بعداً سايش باد واقعى روري به ميان آمده است. حالت بعدى جريان آب رويداد قبلى را تا اندازه زياد تاريخخذارى أين دوره را به حالت آب و هوا (اقليم) مقدم واگذار نموده است. آب برده گیى مانثد مرتبه به نظر رسيده و يقينأ ساختمانهاى اين سنخ هاى ريخى در جاييكه مغاره ها حفارى گرديده تقريباً از

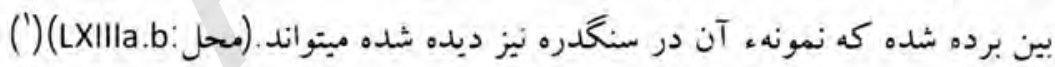

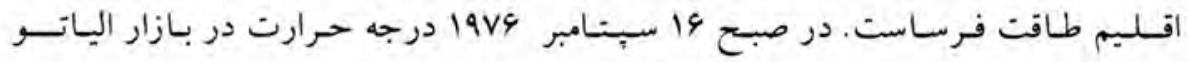
Bazar-e-Ulyatu

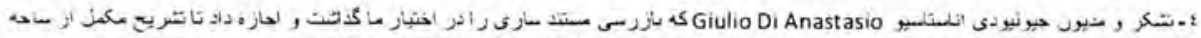
12

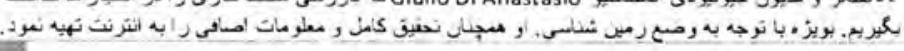
باستانشناسى افغانستان 
برف، بارانهاي بهازى و سيلابها منطقه را براى جندين ماه غبر قابل عبور حر سال ساخته بود

ييرامون دثت ناور و راه آن جِند حرف مختصر ضرورى ميباشد.(شكل 1) به عقيدة زراردفوسمن Gerard Fussman كسيكه محل را در سال 1999 ملاحظه نموده در كذشته جهار راه به دشت وجود داشت: از مالستان به جنوب غرب، از دره سراب و غزبى توسط راه دور ولى آسان، از درة مرتفع لو گر به شمال شرق و از درة خوات به وادى وردكى- راه غبر

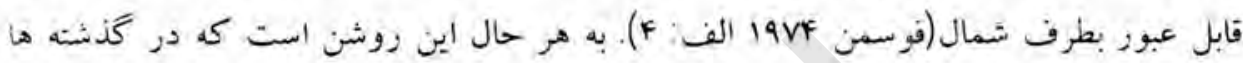

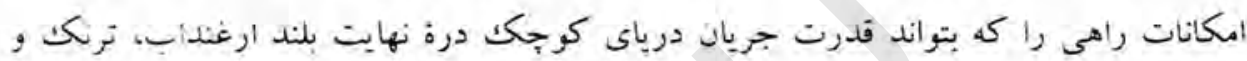
رود هاي غربى درياى غزنى در غرب كوه دهبادى را دور جنوب تعقيب نمايد، وجرود نداتث

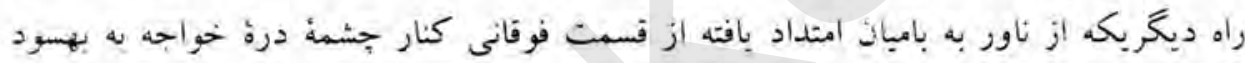
الى درة فوقانى هلمند را تعقيب مينمايد اين بك حقيفت مسلم است كه حط السير نوسط

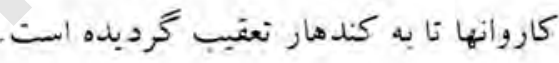

مو جوديت إب راه مشابه نوسط ريورنى Raverty در 1990 هو تذكر و به تاريح سينتان

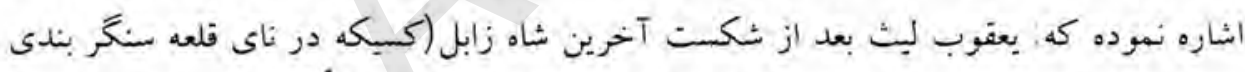

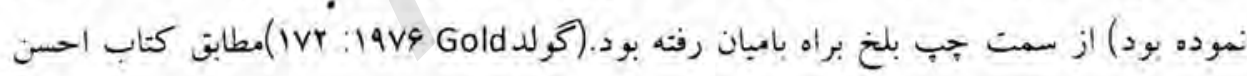
التقاسبم فى معرفت الاقاليم مقدسى اظهار نموده كه يكى از دروازه هاى غزنى در زمان

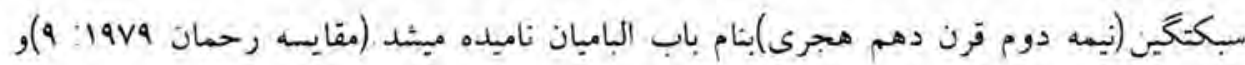
حر حقيقت در آنجا راهى واضع گترديده كه از غنزنى به باميسان از طريق رباط البراد

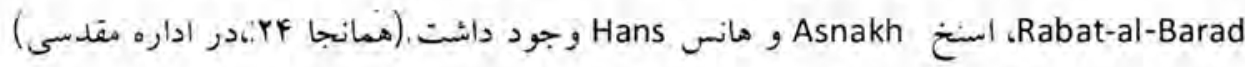


ابن حوقل در كتاب المسالكث و المالكث گفته است كه فاصله اين راه در هشث مرحله (') بين غزنى و باميان ميباشد. Marhala

معلوماتيكه توسط منابع جينى تهييه شده اين باور را ميدهد كه در عصر بودايى در آنجا

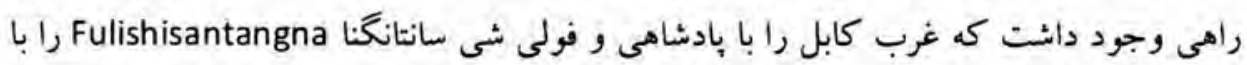

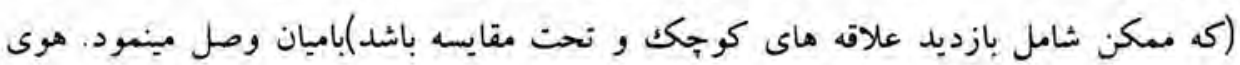
جاو Huichao زايركوريايى كه در سال VrV زابلستان ديدن نموده بود صريحأ بيان ميداردكه از سرحد زابل غزنى بطرف شمال بعنى باميان بيش از هفت روز رادر بر ميكيرد زيرا وى از جيبين لlibin به زابل يا كاييسى-كابل رسيد و او صرف محل تقاطع مسير هندوكش را

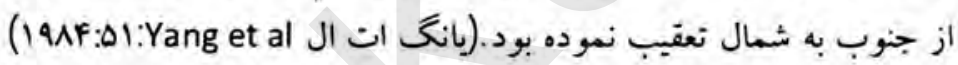

به اساس كشفيات اخيرى كه از يكك كتيه باخترى از تنگى سفيدك كه در صدكيلومترى غرب باميان در هندوكث مركزى بدست آمد روشن گرديد تاسيس ستوبه توسط شاه غزنى در

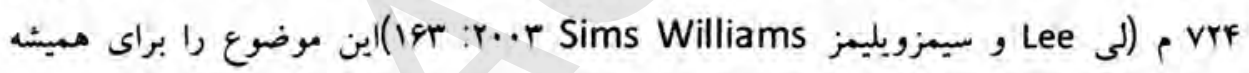
تصفيه كرده است كه سرحد شمالى زابلستان در آن زمان آنسوى درياى هلمند بوده و سرك غزنى به ولايات شمال قلمرو شاهى صرف ميتوانست درة سراب Sar-e Ab را دوباره از ناور شروع و تعقيب نمايد به اين اساس مسافرين ميتوانستند از جنوب و جنوب غرب از بالاى دره هاى ترنك و ارغنداب به جهيل برسند. 
در اخير رسيدن ازين ناحيه به غور و هرات و دورى از راه هاى ديخر نيز امكان بذير

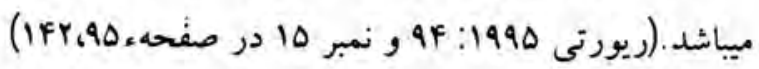

$$
\text { با ب- مغاره ما: }
$$

بخش مغاره هاى جاغورى و قره باغ نه تنها متعلق به يكك محيط جغرافيايى مشتركث بوده بلكه همجنان سهم مشترك اختصاصى در اصطلاح نوع شناسى (تيبولوجى) و تخنيك بكار انداختن تيم كاوش ميباشد كه براى سهولت در آينده آنها در يكك بحث عمومى و فصل جداگانه مطالعه شده و از تكرار در فصل توضيحى جلو گيرى ميشود. در نتبجه ظاهر شدن نوك مذكور در فوق، شكل ديوار هاى سنگى در داخل مغاره ها بريده شده و بخش خارجى آن فرو ريخته بود. يخهاى بارجه هارجه و برف و باران در اطراف صخره تركيده گیى و درز هايى را باز نموده و در تركيب عمل، زمين لرزه منجر به فرو ريختن بيشتر ديوار هاييكه بيش ازين توسط كار كاوشگران سست و لرزان شده بود، گرديد. در نتيجه مانع شدن سد هاى بزرگ باقيمانده حتى اسباب زحمت داخل شدن به مغاره ها شده برعلاوه اين هم خيلى اوقات داخل شدن به دهليز ها و اتاقها نيز غير قابل دسترس هستند.

طوريكه ما ديديم نماى مغاره ها رابطه عمومى با نماى اصلى سنگ قطع معابد نداشته كه امروز ديوار هاى كوهى ماند آبشار هاى سنگى تقلبى معلوم ميشود جاييكه نماى اصلى محافظت شده نظريات عمومى توسط عمل عمومى عناصر طبيعى يا فعاليت و انجام كار هاى هاى دوباره توسط ساكنين بعدى هنگام دورة رهبانى كه در آخر آمدند بيجيج و تاب خورده است. 
آنها از زمرة مردمان هميشه فقير محل بودندكه حتى قادر به تهييه خشت خام براى منازل شان

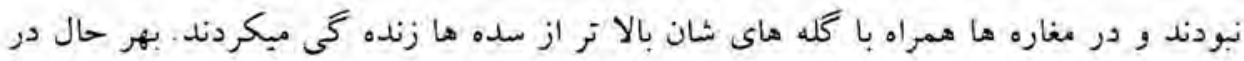
ناى قلعه Nay Qala ما تمونه حفظ شده اصلى نماى خارجى اين مغاره را (مغاره PI.VI.br) و شكل اجمالى تافجه بزرگ (PI.LXXXVIII.b)

حالانكه مغاره هايِكه در ذيل آمده اند از نغاه نوع شناسى، بعضى شان در بِلان بينظير و

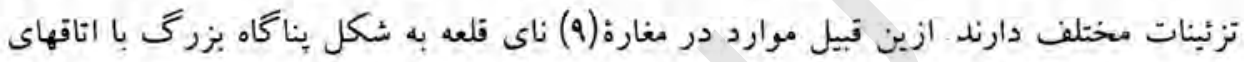

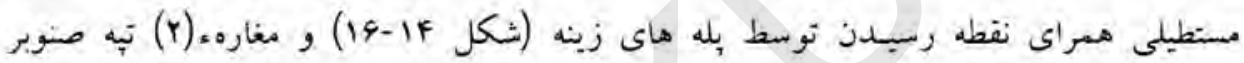
Tape Sanawbar

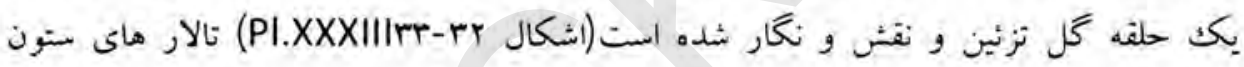
دار، با الهام واضح با نمونه اصلى هندى مانتد مغار (r) در سنگدره Sangdara و مغارة تمبر ه ه در قريه بابا كمال Qarya-ye BabaKamal كه همبحنان نوعى از سنگ قطع هاى اين ناحيه و ديكر محلات مقدس (ينا گاه):نا شناخته افغانستان أست.

مغاره هاى عادى با يِلان مسنطيلى كه هر يِك آن توسط اندكى خميده گیى هموار، يا

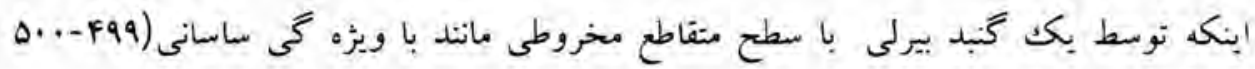

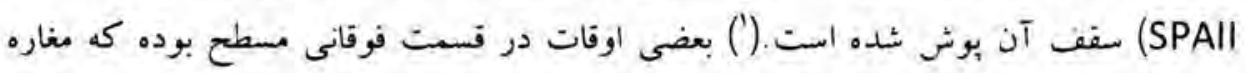
هاى

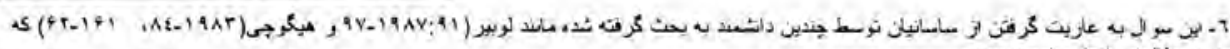
16

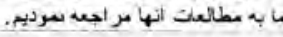
باستانشناسى افغانستان 


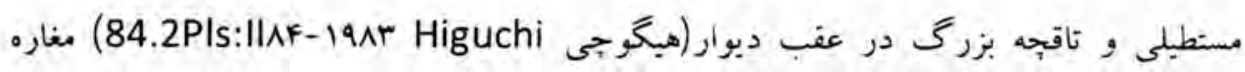

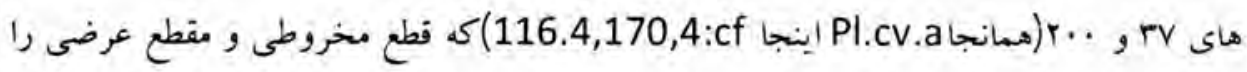
نشان ميدهدحالانكه يوش تاقجه مغاره F ا با هموارى بسبار مغايرت دارد (همانجا PI.36,4) او

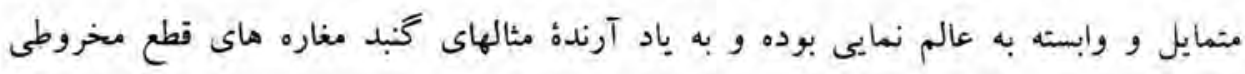
خنجبائى Xinjiang ميباشدكه آنها واقعأ بكلى مشتركت هستند و ما با ييست حلد مقايسه آنرا در اينجا GrosseHohle در منگوى Mingoi نزديك قزل Qizil دانست (PI.CXV.C) همجينين خصوصبات ابئ مهندسى از مرحلهء بعدى ويهاراى مشهور تيه سردار (تدى و

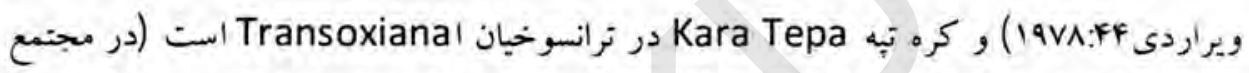

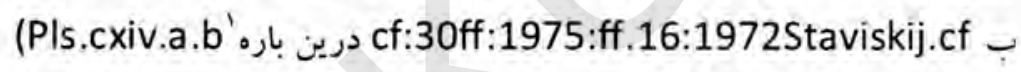

هنگًاميكه يكك يا جندين تاقجه معمولأ هلال تاق و قطع مخروطى را در عقب ديوار جلو يا

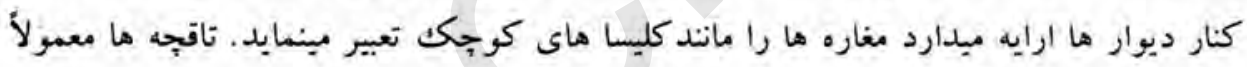

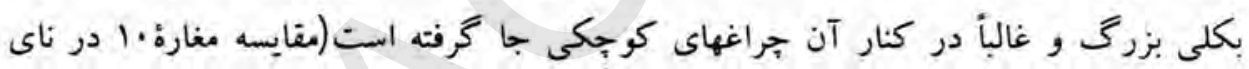

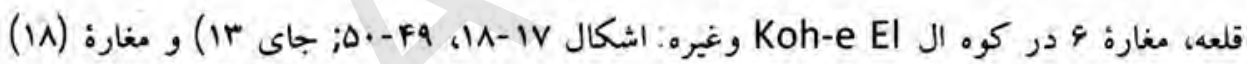

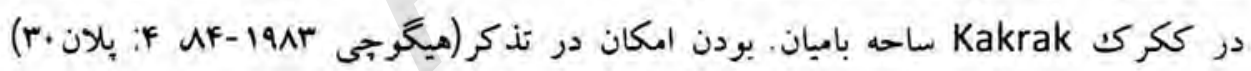

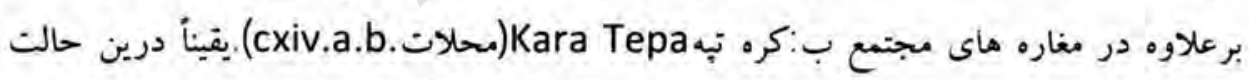
كمان دست ناخورده تاقجه با بخش فوقانى توسط نوارى دولا كرديده كه دنبال كردن ترميم

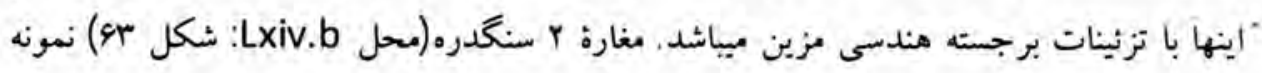

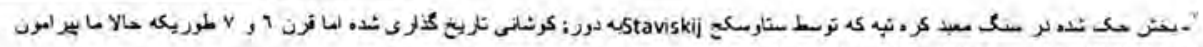
17

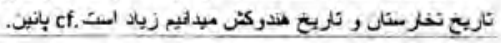
باستانشناسي انغانستان 
ايست از جا دادن سر در كمان يكك نوع تزئيناتيست كه با آن آراسته گرديده است. مغاره در ناى قلعه (شكل .r) كمانيست با سر در برجسته. اين توافق تزئينات در باميان مشتركت نبوده اما جند نمونه آن دريافت گرديده است: مغاره .باه ملاحظه شود.(محل.cvi.a.) در حاليكه تاقجه هاى ذوذنقه يى، يا سه تكه يى نوع شناخته شده باميان و تبه سردار مدركيست در ناى

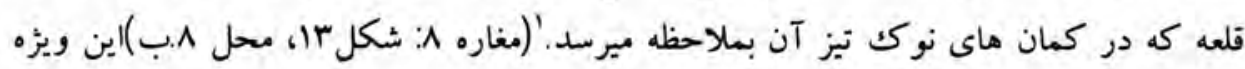

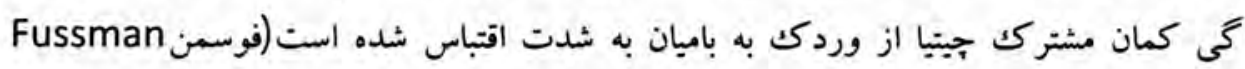
laVFF

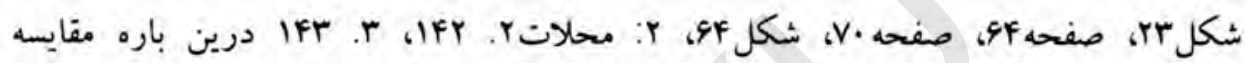
محل IA.C) خحلاصه اينكه در مهندسى ساسانى(محل CXV.b)در ناى قلعه اضافه كردن جوب ياگَج در سطح فوقانى كمان_-جايثيا chaitya به منظور محكم كردن كه در نتيجه بلاستر نمودن بدست آمده، ملاحظه شده است نـ

در امتداد قطع مخروطى بعضى از تاقهاى كنار ديوارها ماند مغاره هاى (1) تيه صنوبر

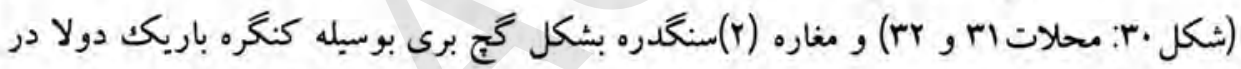

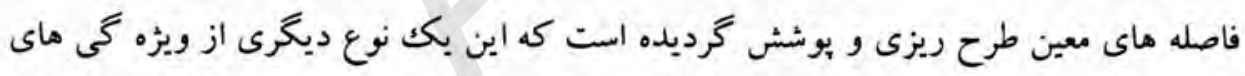
معمارى ساسانى هاست. در تعمير هاى مجزاء ديوار هاى داخلى به تدريج ساخته شده و تغيير

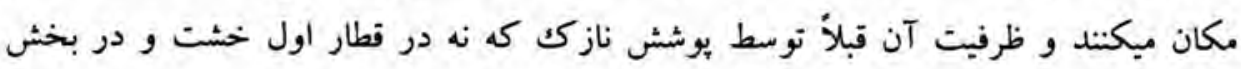
تحتانى ديوار ها كمانها قرار داده شده كه آنها را در خارج بيش كثبده است. مثالهاى مشابه

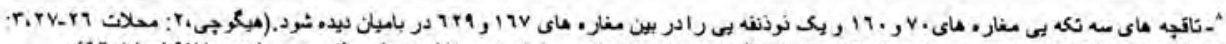

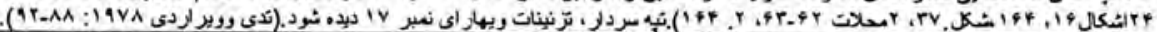




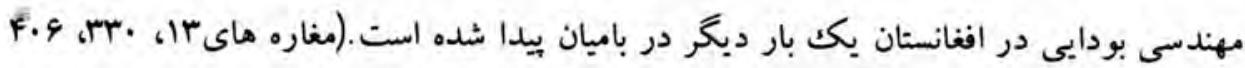
(cv.b.cvi.b) درين باره محلات بودئ

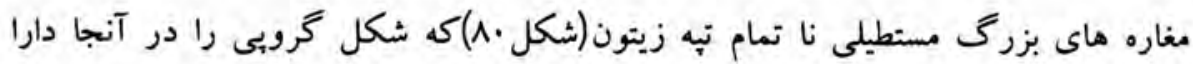

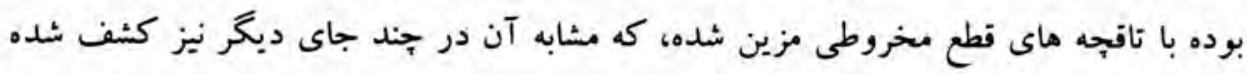

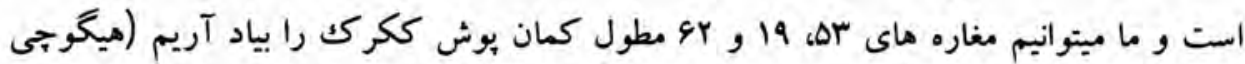

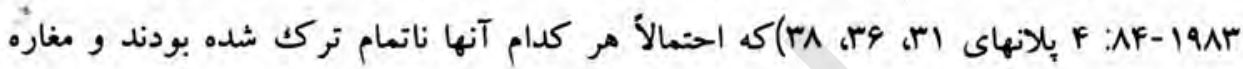

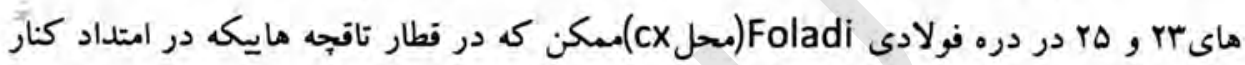

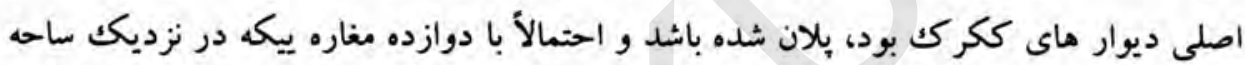
E باسول ديده شده مقايسه شده مى تواند.(درين باره محل:CXI )حفاظت ناجيز و نا مكمل آشكارا مدركيست از تاقجه هاى نا مرتب موجود در امتداد كنار ديوار ها.' حالت فعلى مغاره هاى مطول مستطيلى باتيراس(صفه)با هم مشابه و قوياً ياد آور تبه زيتون است. مقايسه ديخرى با مرتي مغاره نمبر Y هيبك Haybak نيز شده ميتواند. اين اصلى نبوده توسط دو دهليز طولانى

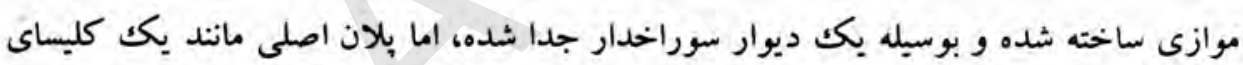
كوجك با تاقجه ها در كنار ديوار بوده است.(ضميمه مقاله ايبك در زير ملاحظه شود) حجره هاى مربع با گنبد ما و سكونج ها(كوشواره ما) مشتركث كه در باميان كشف شده

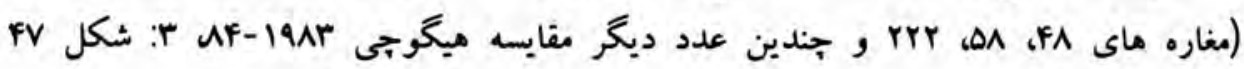

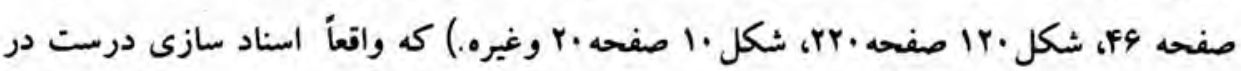




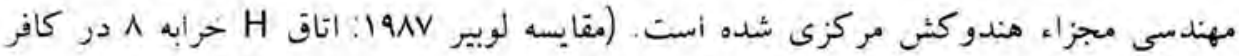

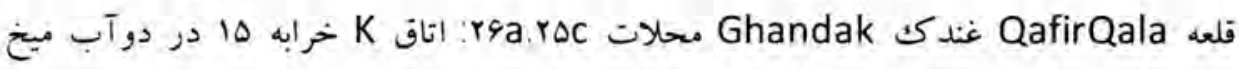

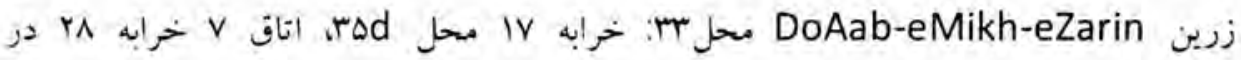
سياهاستا Sepahasta خرابه ادر دريأى شنبل Darya-e-Shombol محل مrbb وغيره.) و

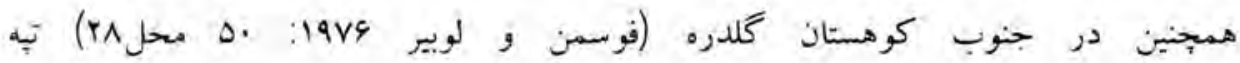

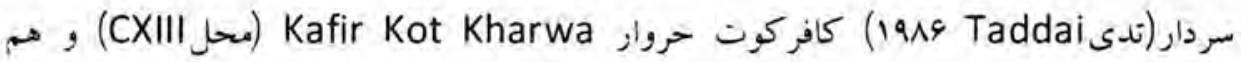
ميتوان با بردن حِند مثال از مغاره r هيبك و تذكر (مقايسه ميزونو 194 Mizuno محلات

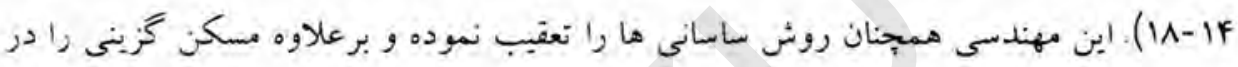
ينحا هويدا ميبازد. حجره هاتى گنبدى و مشابه جاغورى و قره باغ اكنون مشكو كث ميباشند كم مغاره نمبر r تيه صنوبر Tape Sanwber (شكل ابr) ممكن مثالى ازيز نوع باشد لاكن در حقيقت در آنجا أز حفاظت نا جيز هم توصبحى نداده است در بعضى جا ها مينوان شكل ساده شده اين مهندمى را در ساختمانهاي بودايى ملاحظه نمود در حقبقت ممكن كنبدها بأ لوحه بيش بر آمده گیى در كنج ها نمودار شده باشد مغاره

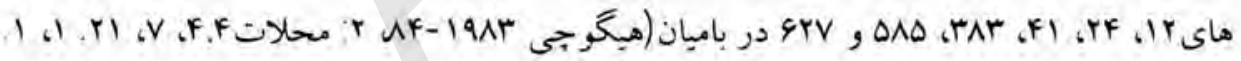

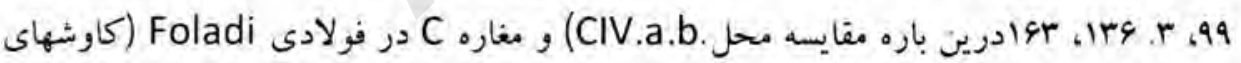
لوبير Le Berre و شلومبرزه 1994 Schulumberger

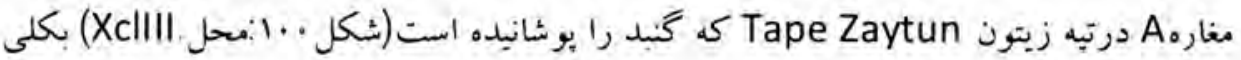

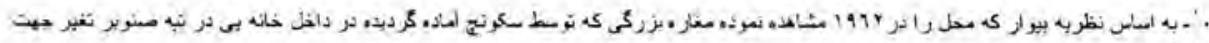


مغار هاى بودابى جاعورى و قره باغ عزنى انغانستان

ازين نوع بوده و بقايايى از ويهاراى گتنداهاراى بعدى ماند آنهاييكه در تهاريلى Tahareli

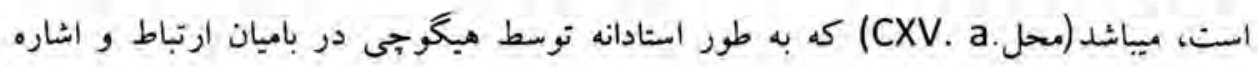
شده است:

همجنان بعضى اوقات كنخره هاى مشابه در مغاره هاى مستطبلى در حجره هاى مربع بافت

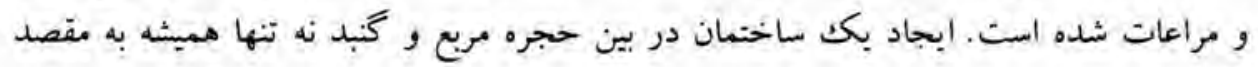

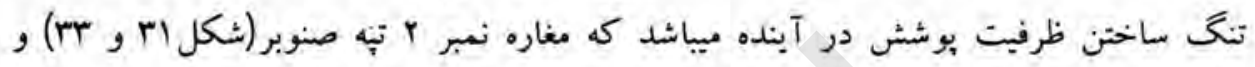

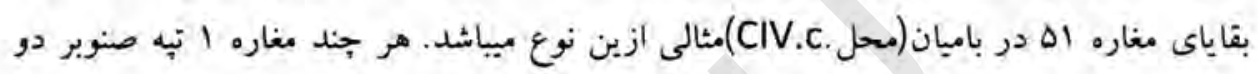

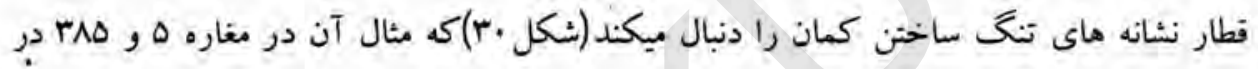

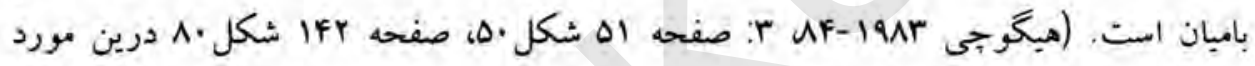
محل CIV.d ديده شود)

سنديكه مغاره ها به اصطلاح توسط Lanternedecke (فانوس زينت دهنده)در منطقه

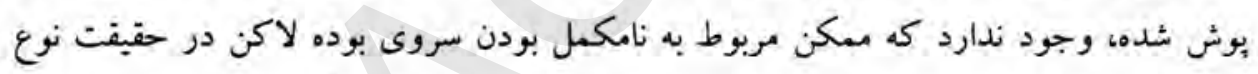

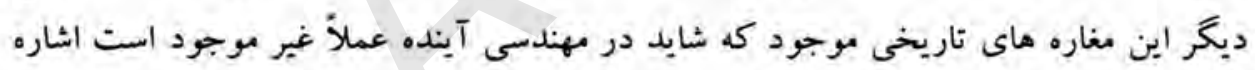

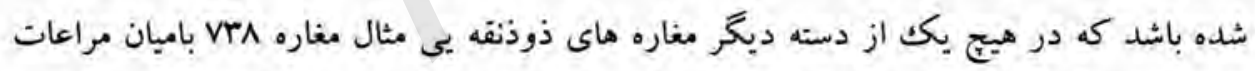

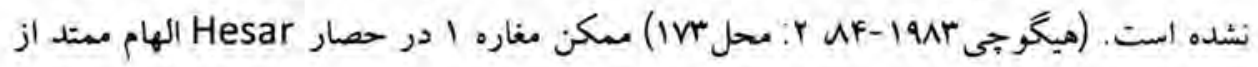

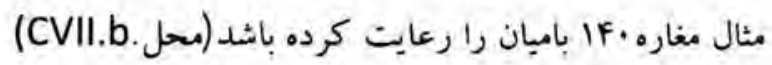
بخش مغاره هاى مستطبلى اتاقهاى بذون تاقجه و عمومأ سفف مموار جاغورى و قره باغ

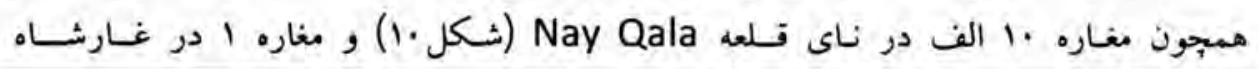
21 باستانشناسى اففانستان 
Ghar-e-Shah

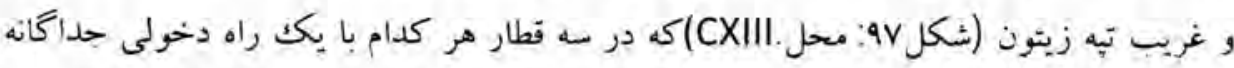

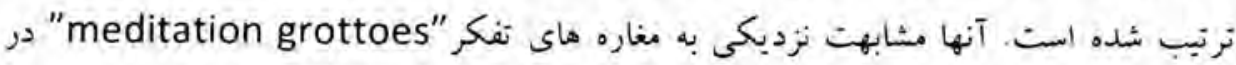

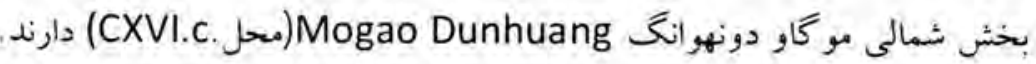

كار ويزٔه در مغاره جيزيست كه دروازه هاى اصلى همئه مستطبل بوده و نشان مبدهدكه

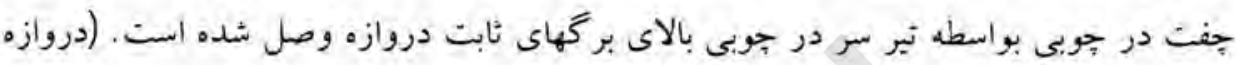

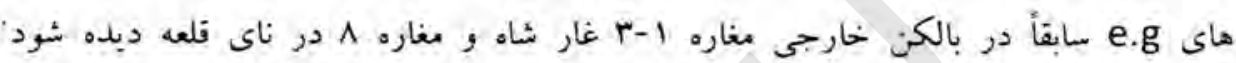

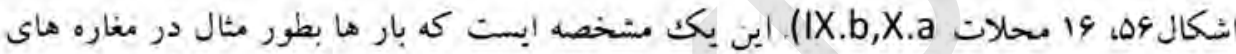

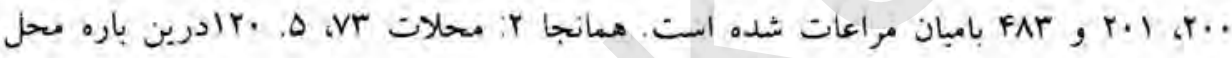

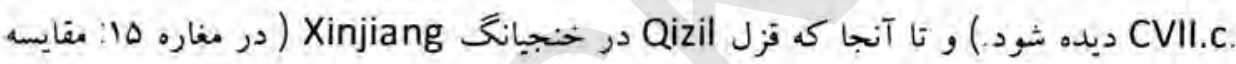
(aijiang Kezier Shiku مغاره هاي جاغورى و قره باغ بار ها به جندين سطح برابر و بعضى اوقات بسبار بلند در

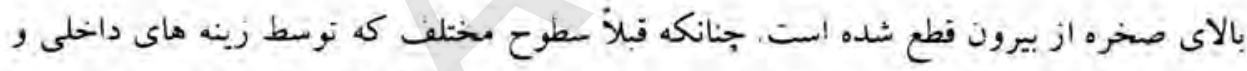

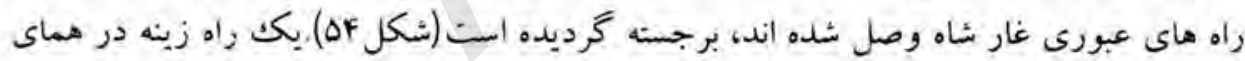

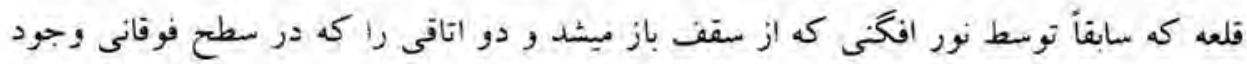

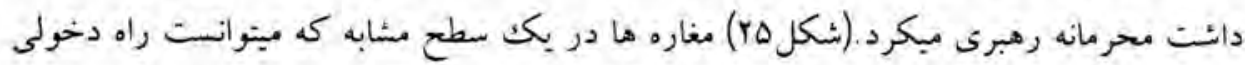

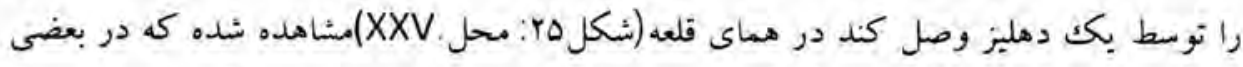

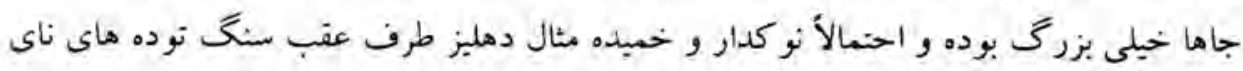


قلعه ميباشد (محل.CVII.b) همجنان ايز نوع دهليز ها و راه رينه ها را در حال حاضر در

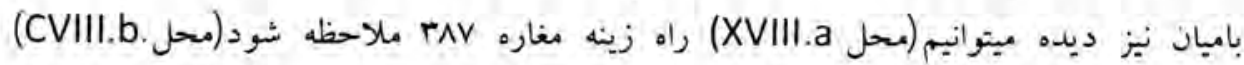

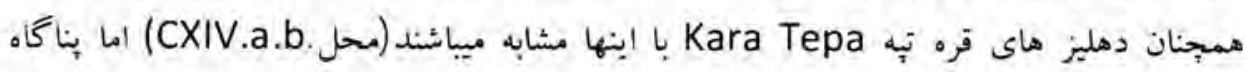
هاى محلى تيلان خود را دارا ميباشند. در بعضى جاها ما توثل هاى واقعى را دريافت كرديم كه راسأ سنغ توده هاى سالمي و

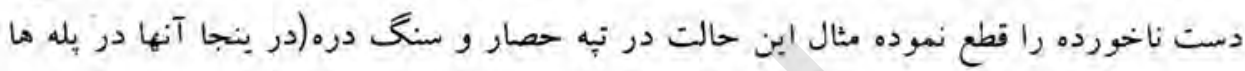
و ارتفاع احتلاف را ستوده، محل. LXVII) وسط كوه را قطع كرده اند تا بياده رو را كوتاه

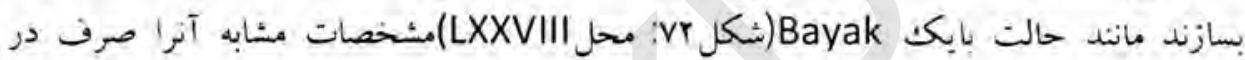
فيل خانه بافته ايم (ميزونو 199VMizuno: يلانV، 9 و .1 درين مورد مقايسه محل. ICXII) در

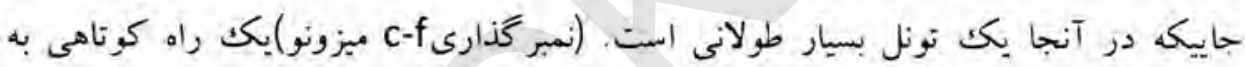
منظور دست بابى به غربى ترين بخش مغاره هايى ايجاد شده كه اصلاً بطرف ذريا باز نشده

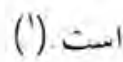

علت اينكه جرا بعضى بقاباي اين گذركاه ها بطرف منطقه قره باغ - جاغورى باز شده تا

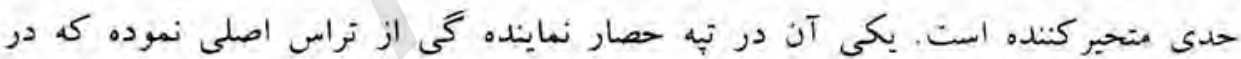
اطراف سنكتوده ملاحظه ميثود و شايد دليل اينكه جرا كاوش شده اين بود كه در داخل رهنمايى شده و اتاقها را محافظت مينهود(صفحه VV) جزئيات سروى أين بخش مغاره ها مسدود كر 2ن و تفكيك باقيمانده تونل ها در درك وظيفه شان لازمى بود

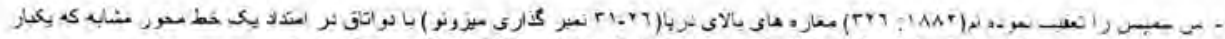

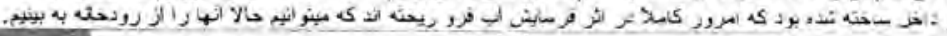
باستانشناسى افغائستان 
به يقين كه در بخشى آز مغاره ها تنها از طرف بيرون با وسايل بيرونى راه زينه و بالكن كه از جوب ساخته شده، ميتوان رسيد در بقاياى ترأس جوب استعمال نشده لاكن در وجود اين مشخصه شواهدى از سوراخها در ديوار بيرونى ديده ميشود ماندل حالت هماى قلعه (شكل :TF: محل. .XXII يا با بكك حقيقت ساده امكان دست يابى به اتاقهاى ديگر نبوده كه دروازه هاى اصلى حالا به خارج باز ميشود ماند غارشاه(شكل وه: محل.LVIII) وجود زينه هاى جوبى خارجي و بالكنى در ديخر نقاط افغانستان دست آويز شده نميتوأند لاكن در مهندسى مغاره بودايى خبنجيانگ Xinjiang به خوبى شناخته شده است در جاييكه بخش مغاره هاى رهبانى

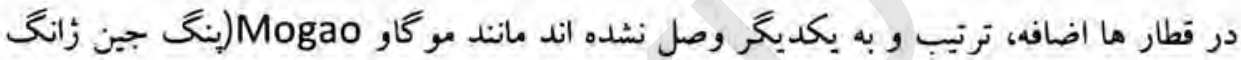

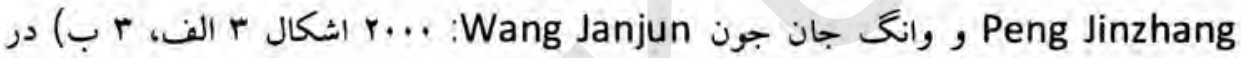
جندين جا راه هاى معابر جوبى خارجى در هنگاميكه اورلستين Aurrel Stein آنرا ملاحظه نموده، حفظ گرديده (ستين 191r r: محل 1ه9). در تزل راهرو اصلى جوبى قبل از مغاره

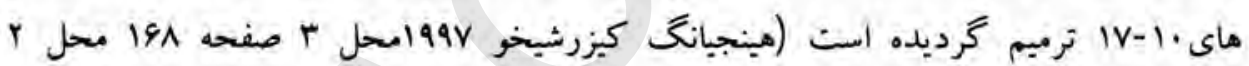

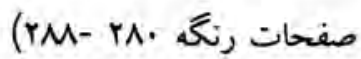

راهبينى كه در كليسا هاى كوجك زنده گى مينمودند شايد بسيار كم به يكك و يا جندين

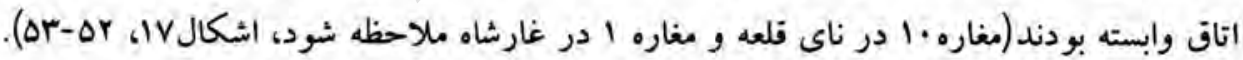
بعضى از آنها به شدت بلان نا مرتب داشته و بيش از همه احتمالأ در زمان مرحله رهبانان گذشته اضافه , دوباره كار شده است به عنوان مثال مغاره الف در گوارجين Gawargin

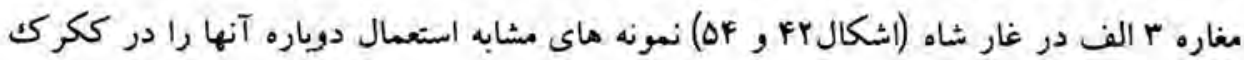




\section{مغاره هائ بودابى جاغورى و قره باغ غزنى افغانستان}

ديده ميتوائيم (e.g مغاره FV محل FV.b. اين اتاقهاى بعدى غالباً داراى يك قانون، سقف نا مرتب وكف زمين نسبت به مغاره اصلى بائينتر است. دستيابى به آنها توسط وسايلى كه با تبر

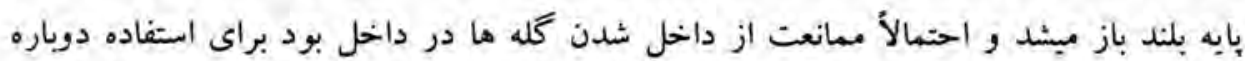

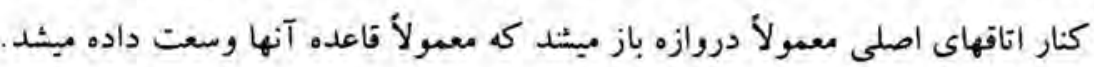

مشخصه آشكار ديخر نشاندهنده تصرف تاقجه هاى طولانى و مستطيلى كذشته رهبانان است كه هم در دوباره بكار گيرى مغاره هاى اصلى باز ميشد و يكبار در كاوشهاى نامنظم

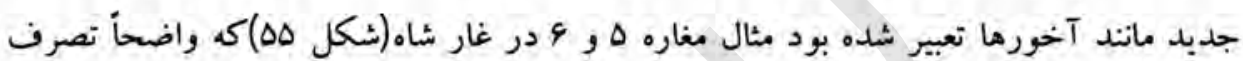
شده و آنها با كله هاى شان كم از كم در هنگام زمستان يكجا زنده گمى ميكردند.

ما در صورت امكان سعى ميكنيم تا مرحله بين اشغال رمبانان و استفاده دوباره آنها را آشكارا تشخيص نمايم مرين اواخر ما سكيج سبماى كنونى مغاره ها را ساختيم ( و هم توسط عكاسى اسناد سازى كرديم)جونكه سكيج قبلى آبدات تاريخى به شكل اصلى آن حين بازسازى لازمى است.

به ملاحظه قبلى با داشتن بهرين محل مهندسى قطع سنخ بصورت بسيار واضح با ساحه قره باغ و جاغورى قابل مقايسه است. اكر جه ساحه آخرى مطابق تيولوجى مانثد تذكر بالا

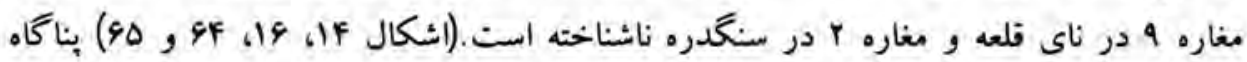
هاى دهقان با احاطه داخلى كه وقتى مجسمه ابرا بالاى ستون بايه ايستاده نموده و در بلان

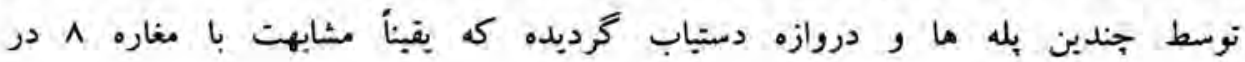




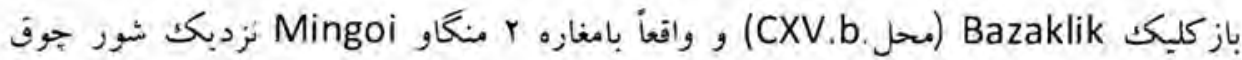
(CXV.b. محارد) Shorchuq

مغاره r بنخدره مانتد بناكاه سه راهروى كه ياد آور مهندسى قطع سنخ در غرب هئد ميباشد طراحي شده است. دو تالار ستون دار در شاكى ناكا Shaki Naka و قريه باباكمال دور

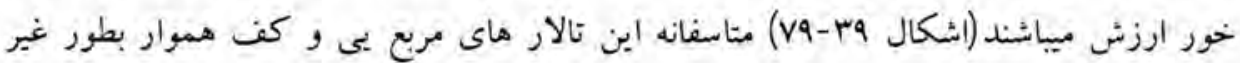

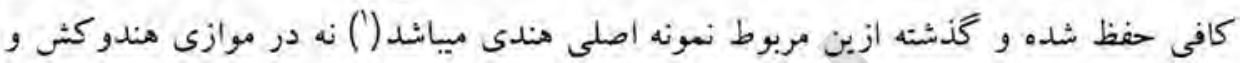
ناحيه هاى شمالى و نه در بهئدسى قطع سنخ در هيج كدام ساختمانهاى محجزاء يافتيم. دريشا كفتار مختصرى ييرامون تزئين مغاره ها بوده زيرا شواهدى بسبار اندكك ناشى از

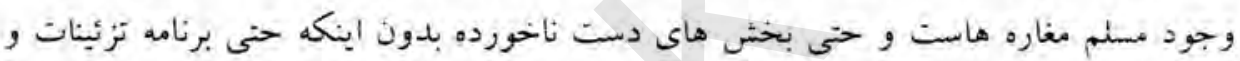

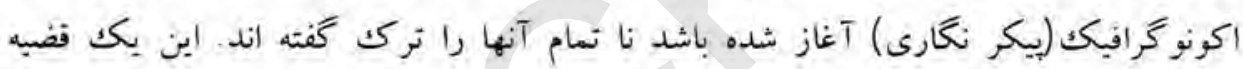
حداكانه ييراعون تيه زيتون بوده و ما سعى خواهيم نمود تا دليل آنرا در ذيل تشريح نمايبم. در حائت ديكر زهبرى مقأ رهبانى يبش آفت خرابى و نا بديدى تزئينات اصلى بود. مغاره ب در

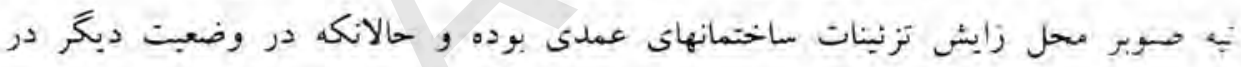

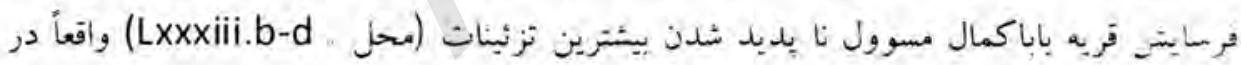
حود معاره ميباشد 


\section{مغاره هاى بودأيى جاغورى و فره باغ غزنى أفغانستان}

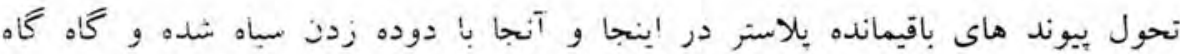

نشاندهنده اثر نقاشى مانند مغاره 9 در ناى قلعه ميباشد. در ايى حا اندكى شكك موجود است كه بعضى مغاره ها نقاشى شده و ديكران آماده براى نقاشى بودند.

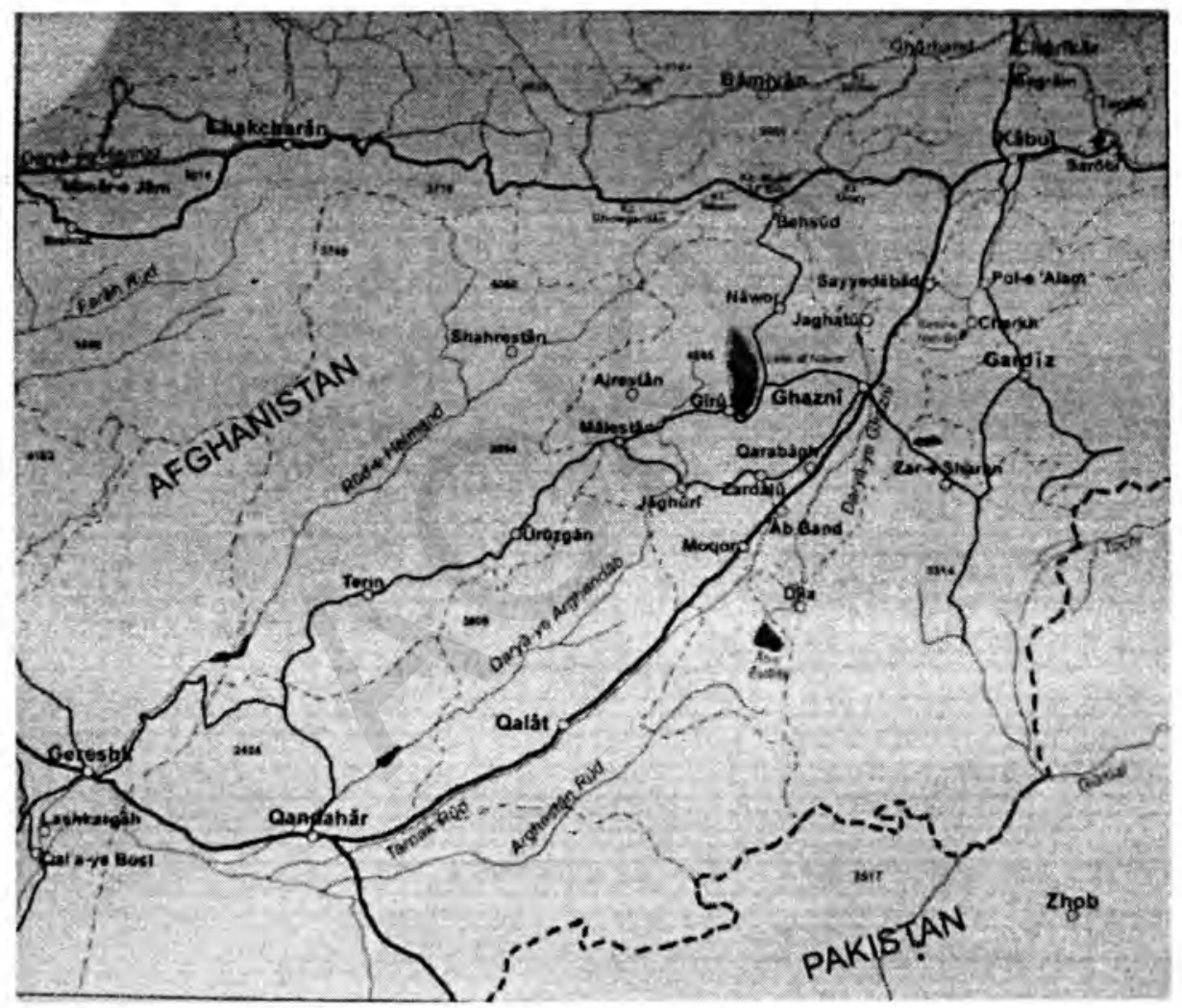

$$
\text { شكل (1) نقشه جنوبى افغانستان }
$$




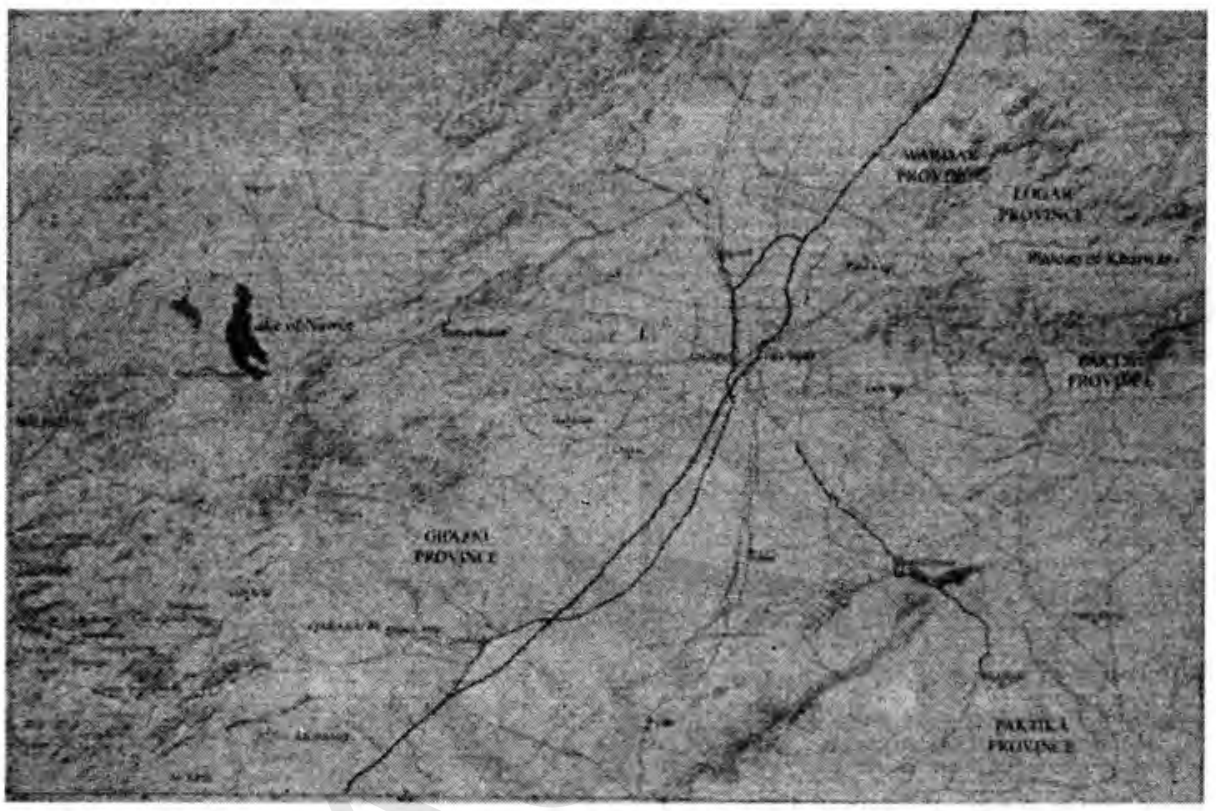

$$
\text { شكل(r) نقشه بخش شمالى ولايت غزنى }
$$




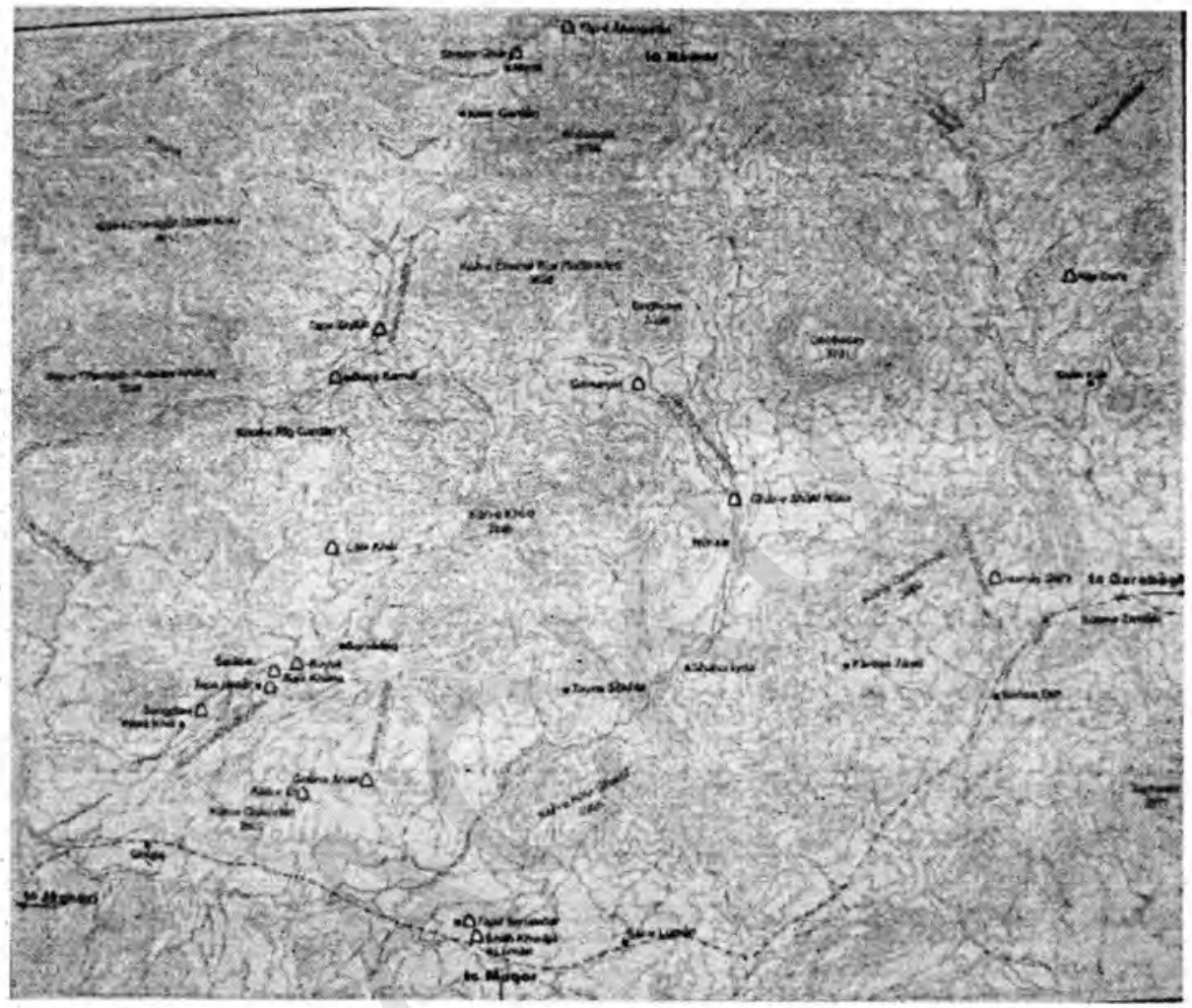

شكل (r) مغاره هاى بودايى جاغورى و قره باغ 
خيجينبوه رازقى نهيوال

د ناكاراهارا لرغوني بنارونه

د مغو بودايي سيمي او Tثار

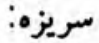

كه به افغانستان كى به واقعيت سره د باختر او آريانا د ((هزارشهر)) دودانيو د مجتمع مفهوم يه درلودلو سره جي ددني خاوري د شمالي صفحاتو به هره برخه كي له خورا زياتو مذهبي ودانيو خخه عبارت وي أو كه له استحكامي كلاكانو، بخوانيو بنارونو او بالاحصارونو جي د دي بري هيواد به هره كوبنه كي موجود او شمبر بي له زركوبو خخه هم زيات و تبر شو، به مشخص هول د بودايي آئين به تهاو د تاريخي متونو او شواهدو بنست هم د دا هول مذهبي بنارونو او

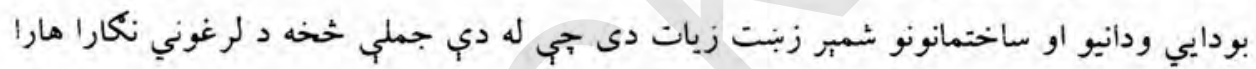

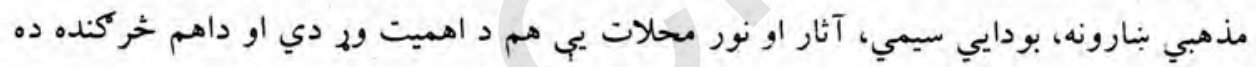
جي د كنداهارا يه حوزه كي د بودايي آئين به ظهور، خبريدني او براختيا كي د ناكاراهارا مقام و تلى كنزل شوى دى لكه جي به دي باب خيه نيوه نظر محمد عزيزي د خبل اثر (ساختمانهاى

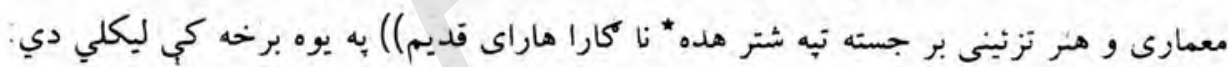

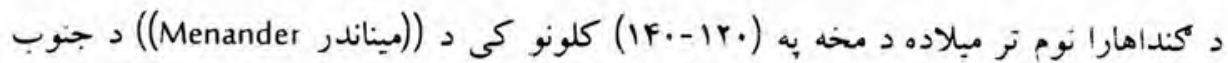
د ((اندو- إندو - كريكك)) د يوتن باجِا جي به مـذهبي متونسوكى د ((مـلاندا)) او ((ميلاند)

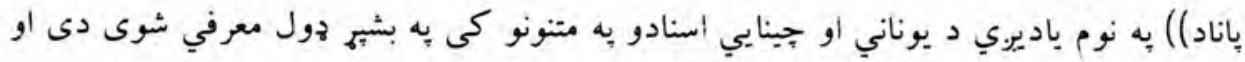

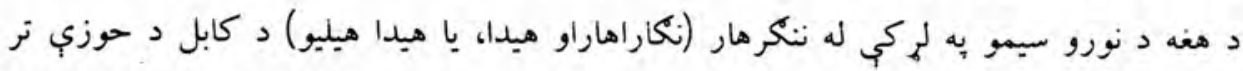


جنوبي برخي به كي شاملي دي. او له دي جملي نه نكاراهارا د كنداهارا له مركزونو خخه

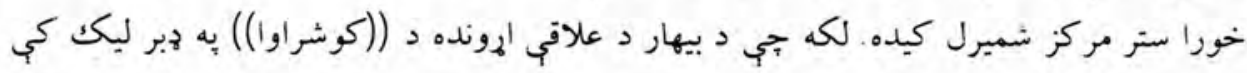
يب يادونه شوب ده. او بب له شكه كله جب نكاراهارا د موريابي ساندا لونوس يا جندرا كويتا او آشوكا تر ولكي او واكمنى لاندي و نو د بودايي دين او نورو تولو برهمني د مذهبي تثليث د دينونو د روزني، بنووني او خبريدلو خورا مهم مركز شميرل كيده (19،9 مخونه).

همدارنكه ددي اثر به يوه بل برخه كي ((كى - لو - هو)) به مجموع كي له مهمو بودايي بنارونو او مركز ونو خخه و د يو شمير زايرينو د شوأهدو او ليكنو به استناد جي له ((ناكى ـ )) او اوسنى هلهي خخه يب د هيليو به نوم يادونه كرى، هم د نكاراهارا له مهمو بودابي مركزونو خخه كنلى او هغه يب د بودا د هلهو كو د بنخيده خأى بللى دى (.r متخ) نكاراهارا ته د بودايي آنين را تكل:

د لغمان(به درونتج كى خب بخوا تر سر خروده د لغماناتو له مربوطاتو خخه وه.) = اخلافي زده كميو او سياربنتو به باب داشوكا (بندو سارا) جي د جندزاكويتا زوى و (تر ميلاده د مخه rrr كال) دوبر ليكك نقر بنيي، جي د نكاراهارا به حوزه كي بودابي آئين دي خاى ته

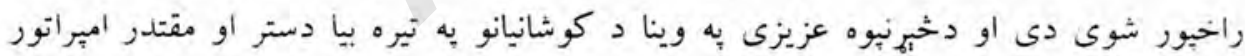

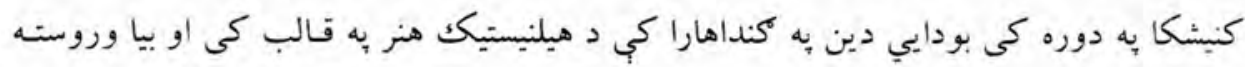

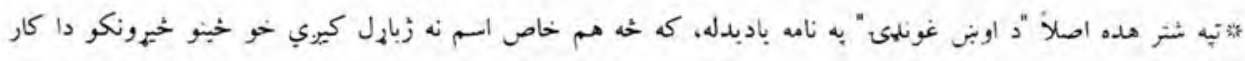

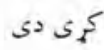


د هندوكش شمال او له هغه لير سيمو بعنى د ((آمو)) له خنلهوهم او بنتلى دى. (هماغه اثر V

يا به يو بل روايت كي راغلي دي جي د مكنداهارا نوم به تاريخي آثاروكى د لوممي حئ

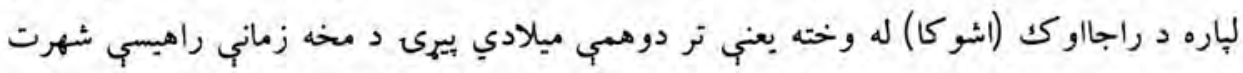
موندلى دى. او د((لرغوني مينب)) د اثر دليكوال د ليكني له مخبي نامكاراهارا د كنداهارا د اداري او مذهبي مركز به توكه د زايرينو د راتوليدني او نمانحني مرجع وه. بودايي آئين جي دلته

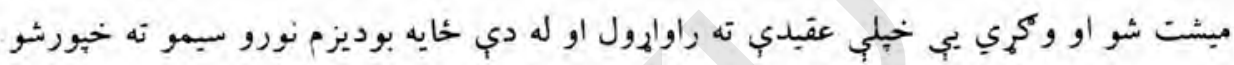
احمدعلى كهزاد ((يه افغانستان كي د بوديزم خيريدل)) د موضوع به ارهـ به مشخص او مشرح هول داسي رنا اجولي ده:

د آشوكا له سترو كارونو خخه جبي دواكمني يوولسم كال (تر ميلاده د مخه كهن كال) اتيكل كيبي د مذهبي غونلهي رياست، د ماهي بنكار منع كول د عباشى منع كول او تر تولو لوى د

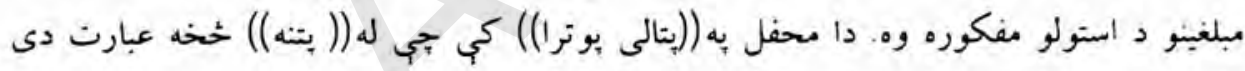

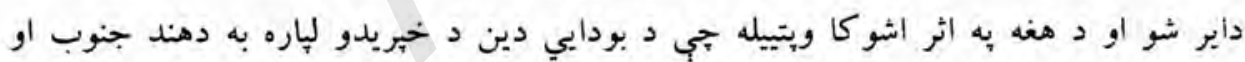
لويديخو هيوادونو ته مبلغين واستوي.

خركنده ده جبي دغه مهال د يوناني شامي سلوكوس منيكاتور د موريا د كورنى د موسس جندراكويتا له لاسه تر ميلاده د مخه ه.r كال د مقابلي يه ترخ كي ماتي خورلي وه او له كنداهارا خخه تر اراكوزي(له كابل خخه تر كندهار) يوري د موريا كورنى برى موندلى و او 
اشو كا هبره هخه كوله جي يخخلو مفتوحه سيمو كي بودايي دين مروج كري، نود همدي مفصد دسر ته رسولو لباره يي د((مجهان كينه))، د ((همهارا كينه)) او ((مهارا كينه)) به نامه خحو تنه مبلغين د كابل، ارغنداب دسيمب خواته واستول او به همدغه ترتيب جي يوهيرو د دريمب م

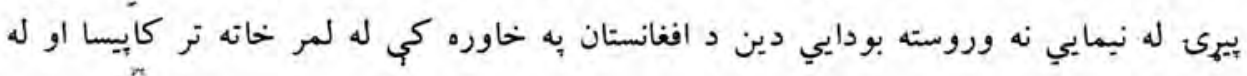

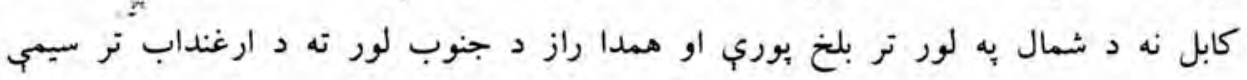
خبورشو، دغه مهال داسي فكر كيده بجي ددي دين خبريدنه به د جنوب ختيخ به نسبت لويديخ او شمال ته زر وشي. خو بر عكس دهندو كث جنوب جي د موريا د كورنى يه ولكه كى و او

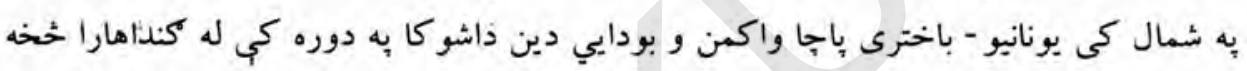
د ارغنداب سيمي ته هير زر د دويمي م. بيرى به نيمايي كى خهور شو. جيني زاير هيوان

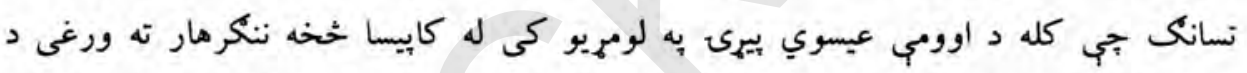

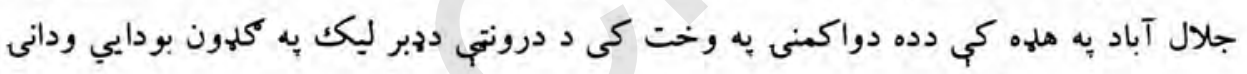

جوري شوي دي (l) (l)

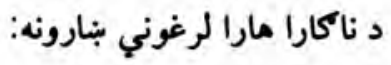
كه به هيواد كي د بودايي آين إووند مركزونه جي د بناركوتي او بنارونو به بنه رامنخ ته شوي دي، وكورو ددغو مركزونو به دهر كم شمبر كي كه خه هم د طبيعى او بشري خطرونو د د مخنيوي او خونديتوب به خاطر دهغوى د جغرافيوي او تويوكرافيكي موقعيت او دخزوندانه د

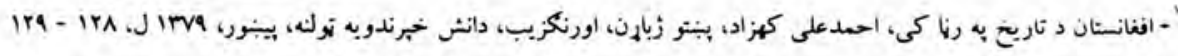


اسانتياً وو شرايط به بام كکي نيول شوي وو، لكه د هيواد د استحكامي كلاكانو (بنارونو) اوبالاحصارونو غونلهب جي د تدافعي عناصرو اهميت يب دومره به نظر كى نيول شوى نه و. او به عام zول يو شمير محدودو مركزونو د بالاحصار بنه درلودله جي د بيلكي به توكه د كابل بالاحصار، د كمرديز بالاحصار او د لوكر د خروار بالاحصار او نور(جي تري مستثنى كملز

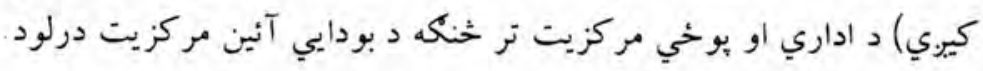
مكرد نامكارا هارا بنارونو به عمومي جول يواخي د بودايي آئين د مركزونو ماهبت درلود او به دي ترتيب معرفى كيداي شي هله يا هيليو:

هله جي دهله يا د بودا له كوبيزى خخه اخيستل شوى نوم دى خجي به ((هيليو Hi llo) هـ

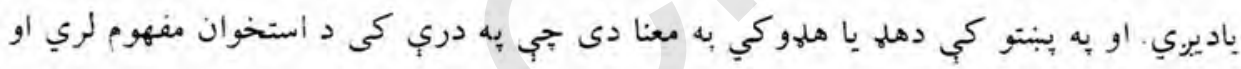
به دي خاطر به هلهه شهرت لري جي ددي خاى به بودايي معبد كي دبودا د كوبيرى هلهوكي

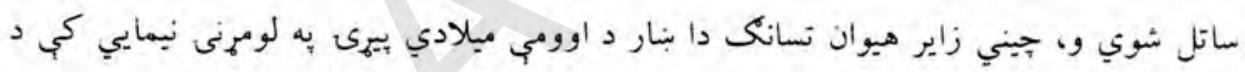

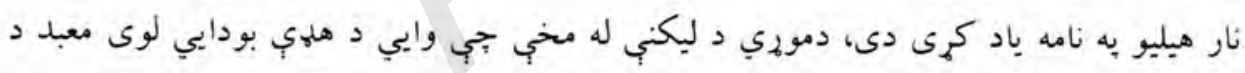

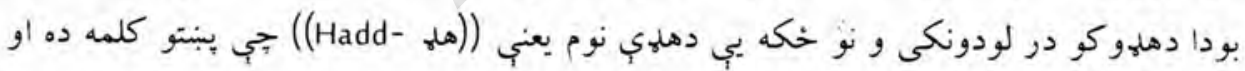

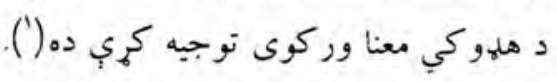

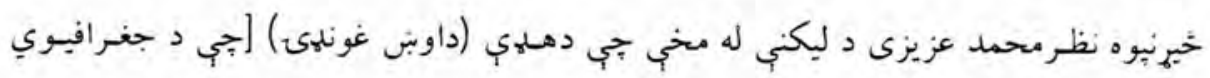

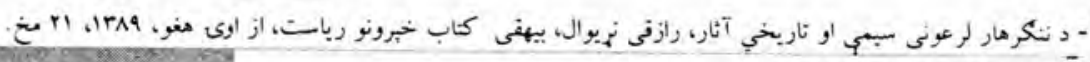
باستانشناسى افغانستان 
موقعيت له بلوه د اوبن شكل لري] يا جترو ديشى يعنى د بخوانى ناكاراهارا دهلهي كردن كوتا

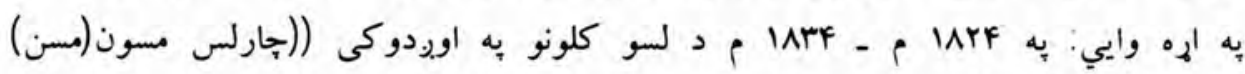

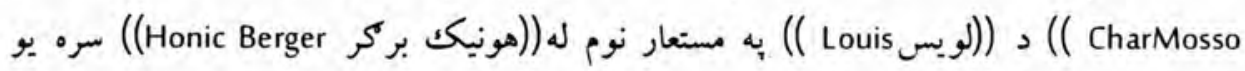
خاى أو همدارنكه د درونتج لرغوني سيمي به تيره بيا د تور غره له لمنو د سيين غر تر لمنو

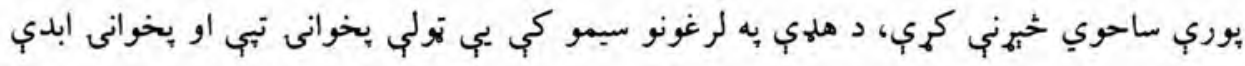
جي خيني يب د مسمى به نوم د سيمي خلكو بري نومونه ايبودلي وو او اوس هم به هغو نومونو ياديوى خو بيا هم مسن به يو شمير باندي نومري وهلي دي ('). د بروفيسور دكتور طرزى به ونيا به خينو مواردو كي دا تبه د((جتروويشي)) به بنه هم راغلي ده د اوبن غونلهى د فاصلو دانحنا بهه شكل د جلال آباد د بنار به با با كيلو مترى او به مستقيمه فاصله به (V) كيلو مترى كي له بناره ليري يرته ده. او د لرغونو سر شارو اثارو او مهمو ساختارونو در لودونكي او د كنداهارا د هنري دوري رنسانس شميرل كيري. د اوبن غونلهى بودايي معبد(سنكهارامه)ددي غونلى منخنى برخه تشكيلوي، د تبي به دوإو خوا وو يعني به جنوبي او شمالي إخونو كي د موبدانو او روحانيونو استو كنخى موجود وو.

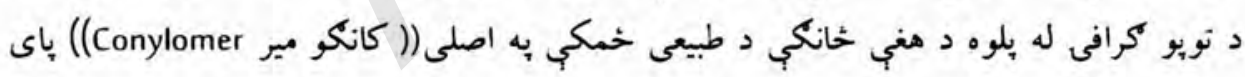

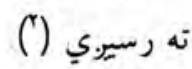

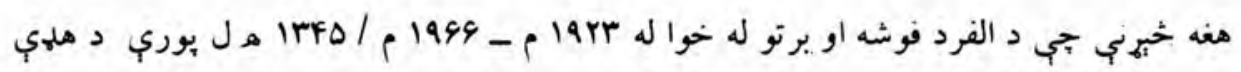

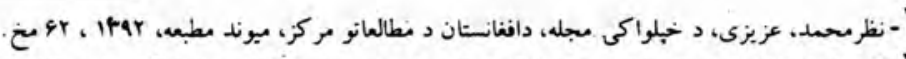

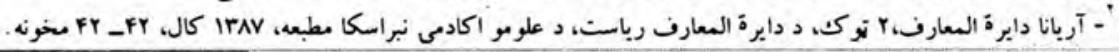


به إجوندو ساحوكي تر سره شوي د سيين غره د لمنو به سيمو كي يب دا ساحي د يادوني وردى. توب كلان (تهه بزركى)، باغكىى، شاه خيل غونلهى، تِه كافريا، دونو، تهيه خزانه، براتس،

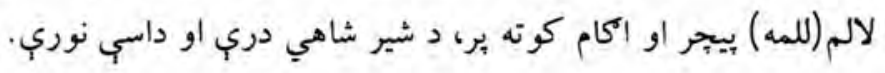

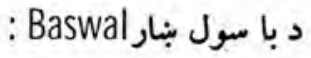

د ناكاراهارا له مهمو بنارونو او بودايي سيمو حُخه يو هم باسول دى. دا خاى د كابل د سيند مسير بنسى خواته او د ننكرهار د ناوي دويالي به شمال ختبحه برخه كي يروت دى او يا باسول د بخواني ناكاراهارا او اوسني جلال بنار د جنوب ختيخ به (.0) كيلومترى كي موقعيت لري بري دا سيمه د جلال آباد له مركز، او د خيبر ددري تر سبمو وروسته د تورخم أو بيا د بيسبور بيه استقامث لار غخيدلي ده.

باسوّل جي د كابل سيند به اوبردوكب بروت دى ديو شمبر أويكانو او كليو درلودونكى دى.

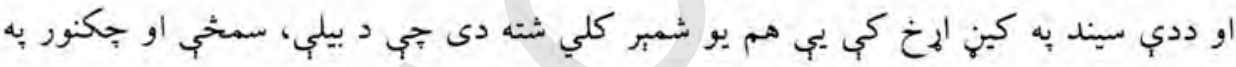
نومونو باديري.

د باسول اهميت يه هغو نبو بوري إِه لري جبي د هغو به أوبردوكي د هسكو غرونو لمى شته دي او يو مهال يب هلته هغسي به زهره يوري موقعيث دولود او له خانكامي اهميت خخه برخمن و او يوه هغبي سيمه وه جب د بودايي آئن بيروان او مرنضان هلته اوسيدل او به عبادت بوخت وو خو اووس هلته هغه ابانى او يرتم كم ليدل كيري. 
ددي سبمب خلك د سيمه ييزو او به بخو انى طريفي د جوروشوو جالو به واسطه د كوثير

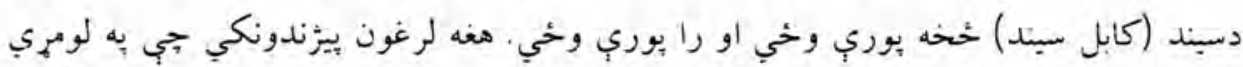
كرت يب ددب سبمب د فرهنك، عفبدو او معمارى د سبك به باب زياتي خبهني سر ته رسولي دي او به هغه سيمه كي جي له بخوانى اورددي زماني راهيسي د بودائي معبدونو او استو كنخيو

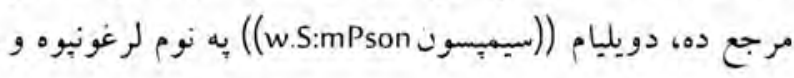
همدارنكه د جايان د كيوتو يوهنتون لرغونيوه به دي سيمه كي هميشنى خبهنب تر سره كري دي أو زموبو د هيواد به فرهنكي تاريخ كب يب خورا زيات كتور معلومات ور زيات كري دي. دباسول سبمه د بودايي آئين يوزي يوه مربوط ساحه وه هغه اثار أو علايم جبي 2 نومورو بوهانو له خوا كثف شوي د خلورمب او بشخمب ميلادي بمكى يوزي يب تمأو درنود د باسول به هنري او د معمارى د خانكهيو شتمني او د هغو د سمخو صورت بندي بي له شكه د كنداهارا د هنري مكتب اغيزمني به هاكه كوي. هغه ختهن او ستوكي لوبني او شرقي

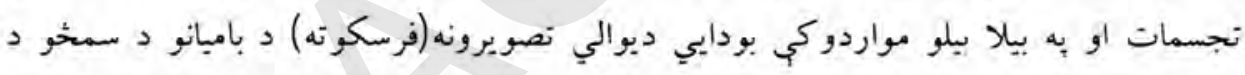
هري مكتب د دم متريزي او هه منريزي محسمب د رواقونو او د كنداهارا د حوزي د وروستيو دورو د تاريخي اثارو سره ورته والى لري جي د مهندسى سبك أو شيوه او د هنري محاسبو تركيب بندي يب به هندي سبك او شبوه ده.

اولكه خنكه جي به باميانو كي تركيبونه د ساساتو ـ كويتا له هنر سره ورته والى لرى: هيوان

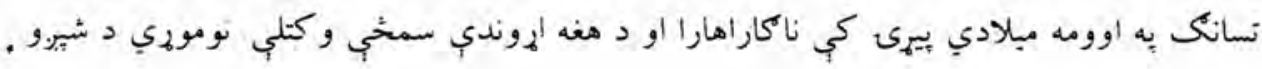




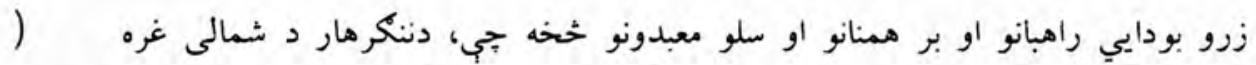

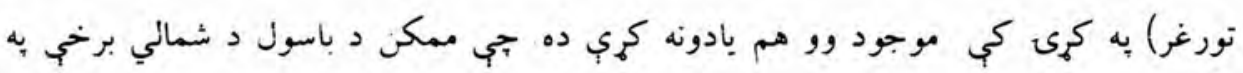
دوام د نوموري جينايي زاير د ريوتونو له بيلكو خخه وي(').

خيهين نيوه نظرمحمد عزيزى به خبل اثر ((اثار و ساحات مناطق جنوب و جنوبشرق افغانستان)) كى د بيجيرو اكام به باب ليكلي دي.

د بيجيريرو اكام لغوي معنا ((د كلونو كيلهى)) او به دري ((سبد كلها)) او يا د كلونو د محل مفهوم افاده كوي دا بنار د آب و هوا له يلوه يوه به زله يوري سيمه ده جي د افغاني

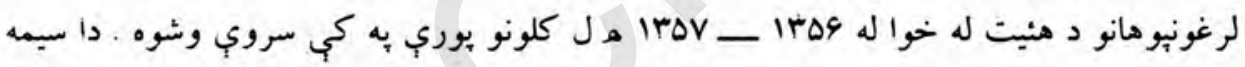
د بو شمير بودايي معبدونو لرونكي وه. د معمارى جوه بنتونه يب زياتره به يوشه ييز (ديايرى) شكل د بجى سرواستي وادا مهاياني به طريقي يوري إه لري سستماتيكي خبهني كمى نه دي

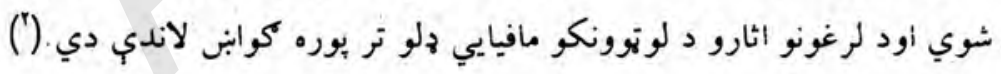

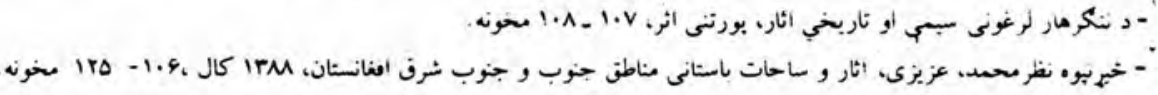


د سلطانيور بنار:

سلطانيور جب به بخوانيو وختو نو كي د لغماناتو مربوط اود ناكا را هارا يو لرغونى بنار و.

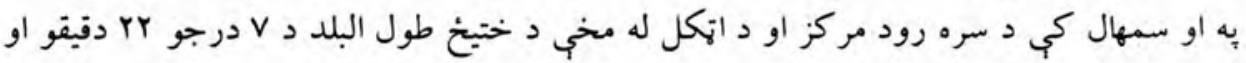

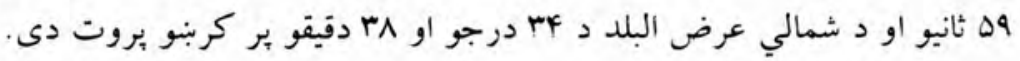
سلطان يور به دوو برخو كي د خهينيز اهميت درلودونكى دى. ـ د بودايي آنين د ستويو له يلوه. ـ د بابا نانك او دسكانو دويساكك د عنعنوي جشن له بلوه. د كيرهارد برنس، رٔاكريت او ويليام سيميسون انكليسي افسران جي د امير دوست محمد خان به وخت كي به جلال آباد كى وو، د ننكرهار د بودايي سيمو به له كمى د سلطان يور به ستوبه

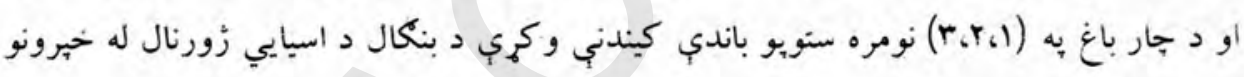
اود انتيكو آريانا د نشراتو د يوي برخب به اقتباس سره داسي ليكلي شوي دي:

دكتور هونيك ييركم جى د درملني يو طبي او در ملكر و، د انكليسى جارلس مسن سره يي د درونتي، جار باغ او بسانى به ستويو كى كيندني وكري. لكه جب خر كنده ده به سلطان

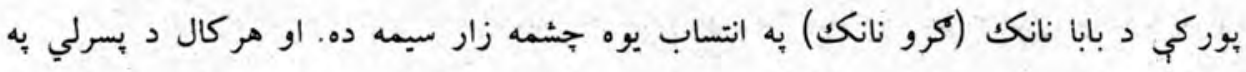
موسم كي د نهى د يو شمبر سكانو او د افغانستان، هند او باكستان د سكانو به كلهون دويساك مذهبي جشن تر سره كيري. به هيواد كي د خو كلنو جكه. ييزو شرايطو تر مخه به دسك 
د مذهب يبروانو اته شيب ورخي روز به سكان دلته راتلل خيمب به يب وهلب، مبلي به يب جورولي خيراتونه او دعاوي به يب كولي، داسي وخت هم راغلى و جي به يوه شبه كي به يبي

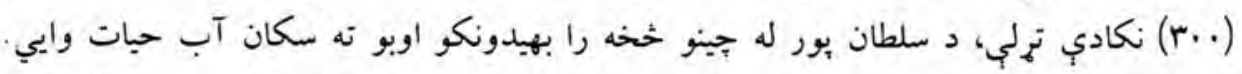
اود جلال آباد سكان يي د تبرك او سوغات به نوكه د نورو خايونو خهلوانو ته استوي(').

ددنيور بنار:

دا بنار جي به دنبر، ادينه بور، د نبور، دنير او به نورو نومونو شهرت لري د محمد ظهر

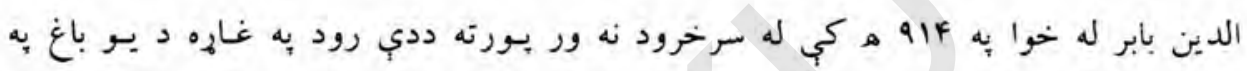

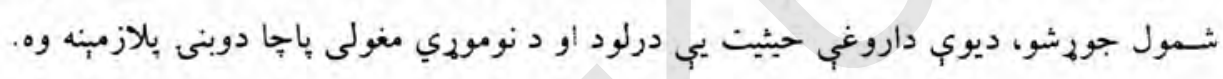
د جلال آباد بنار:

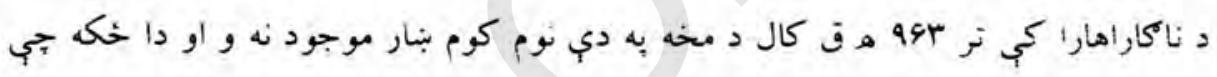
د نيور ددي سيمي اداري داروغه وه او له بلبي خواته هلهه د بودايي آئين مهم مركز و. جلال آباد جي له كابل خخه به ختيخ كي د .010 كيلو مترو به واتن ليري يروت دى

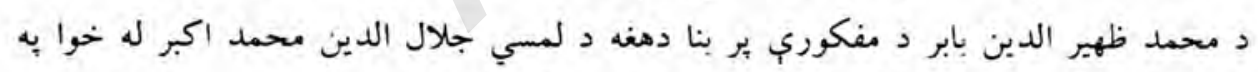

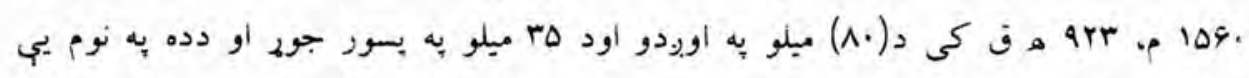

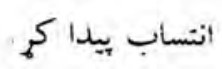

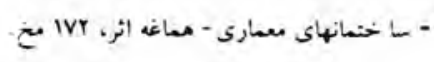


متاسفانه جي به هيخ يو اثر كى ددي بنار د ساختماني سبك به إهه معلومات تر لاسه نه شو، خو داحتمال له مخي يي د درمسال شاو خوا ته يي د جلال آباد، تورخم واتِ به شمالي برخه كي موقعيت در لود. او ختيخ دروازه جب بنايي د ننكرهار داوسني محبس به برخه كى به وه،

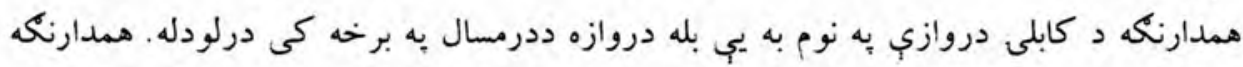

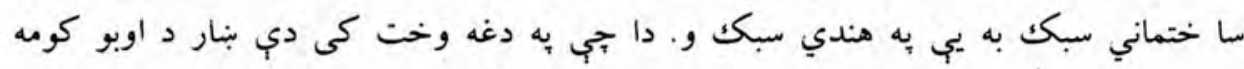
زيرمه نه درلودله نو د خندق موجوديت يب هم احتمالي بنكاري.

د درونتي بنار:

ددرونتي لرغونى بنار جي د نكاراهارا له مذهبي بنارونو خخه و او د لرغونو آثارو د درلودلو

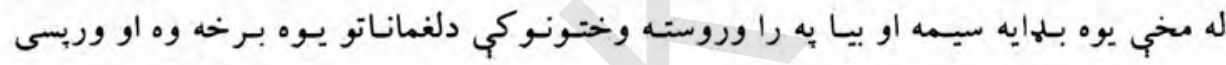
د ننكرهار كانال د يروزي به بشيريدلو سره له خانكيمى ارزبنت خخه برخمن شو.

دابنار د تور غر د لهى د شمال لويديخي خوا د وروستني غابني او د فرهاد او شيرينو به

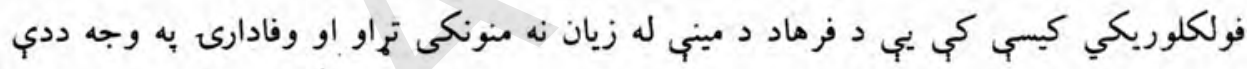
برخي د غرغوخولو او داوبو د تيرولو اسطوره به عامه ذهنونو كي لازٔوندى باتي ده.

ددرونتي = كانال د بروزي تر جوريدو د مخه جي من يب د منيراحمد نزيهال له خوا د كتيب له عكس خخه. يه دي هول د لوستلو، دى: 


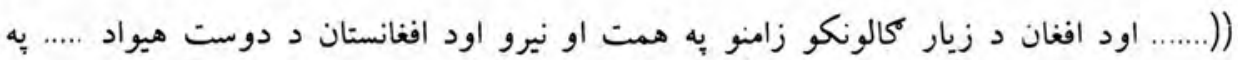
همكارى د ننكرهار د اوبو د لكولو د كانال او بريبنا بروزه به هبrا ل كال شروع او r لمريز

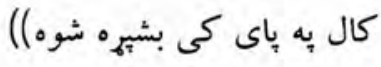

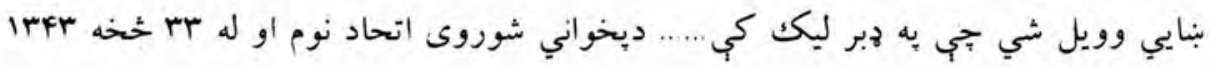
مراد دى جب د مجاهدينو قدرت ته د رسيدلو به مهال دغه نوم او نيته له حبر ليك خخه وهل

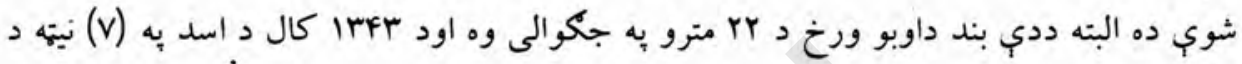

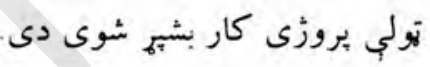

لكه جي د مخه وويل شو له دي بيروزي نه د مخه د امير حبيب الله خان (امير شهيد) د سلطنت

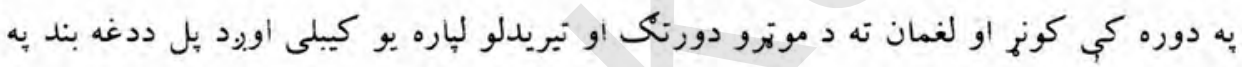
برخه كى وترل شو، جب بيا هم د منيراحمد نهيوال له خوا يب د هبر ليكك له عكس خخه به دي عبارتونو دا متن اخيستل شوى دى:

(اجون اعليحضرت سراج الملته والدين اميرحبيب الله خان درانى باركزائي محمد زايي درين موضع كه ..... است به درونته بر ساختن اين بل حكم فرمودند، لهذا درست در سنه يكهزار وسه صد و بيست و هفت هجرى حسب الامر همايونى بمهندسى مستر جى. آر هليايي انكليس...... اختام يذيرفت.)) د يادوني وهده جي ..... عبارات بي مطلب اخيستب باتي شول. ددي بند له باسه د تور غره لهى د بيل به باسنى برخه كي دواهو ته د اميرعبدالرحمن خان به دوره كى د كونه د ترى د اسـانو او قجرو د لاري غوندي ديسوي لاري نبنـاني تر اوسه بوري 
دهغه طبيعي موقعيت له مخي جي د بودايي معبدونو، مركزونو اود ستويو د جورو لو للاره خورا مناسب او به شرايطو برابر محل دى، نو داده جي دله د بودايي آئين د بيروانو له خوا بودايي تاسيسات او كريكو - بوديك د مدنيت او صنعت د آثارو نبني نبناني به وديوشه شتون لري جي د ناكاراهارا د لرغونو سيمو د بحث به سركى به يري رنا واجول شي. د درونتي د بودايي سيمو د حخيخو تاريخي لرليد: د درونتي بودايي سيمي جي له تورغر خخه تر سر خروده هاخوا تر سيين غره او د كابل سيند كين أجخ ته له درونتي خخه د بهسودو تر بله بوري د تيو لمني رانيسي د لرغونيوهانو له له خوا به كى به دي ترتيب خثهنى سرته رسبدلي دي.

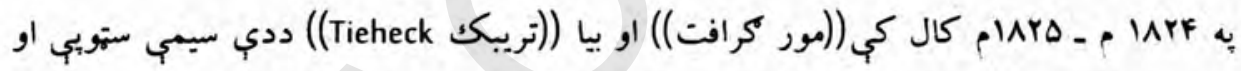
د سمخو تراسونه دكتل او بيا يوبل وروستني خحيه ونكي ددي مطالعاتو به احه يادبنتونه واخيستل. A 1AY ماله وروسته جنرال كورت د ختيخ هند دوايسرا يوخي بياده جنرال جي د امير دوست

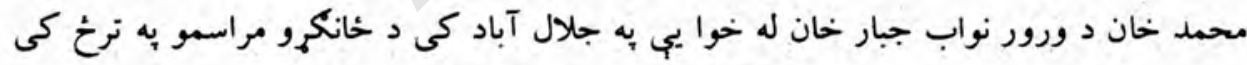
هر كلى وشو د نورو لرغونو سيمو به لإكى يي د درونتي ساحه هم وكتله.

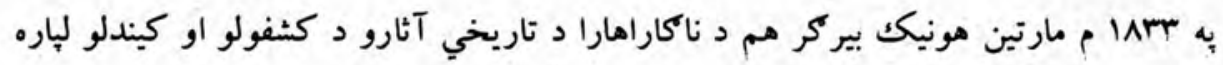
دلته ورغلى و او ترده د مخه به MYM م د جارلس مسون انكريزى جنرال به دي سبمو كى به 
عملي كيندنو بيل كرى و أو د خِلو كيندنو به ترخ كبي يب د بودأيي دوري بي ساري آثار

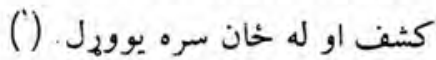

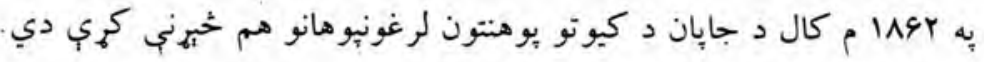

ددرونتي سيمب به دي ترتيب يو شمبر ستويب درلودلب جب د بيلا بيلو بودايي آثارو لرونكي او د بهرنيو او كورنيو له خوا به كي كيندني شوي او يو شمبر يب لوبت شوي وو.

\section{جان توب :}

جان توب(دجان تهه) ددي غونليى ستوبه د درونتي به شمال كى برته ده او رr داني سكي به

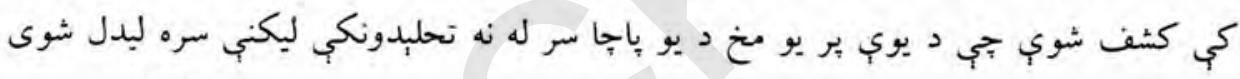

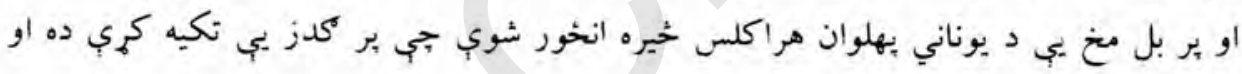

$$
\text { نسبتا بنه ساتل شوي ده. }
$$

$$
\text { د امر خيلو د تيب ستويه: }
$$

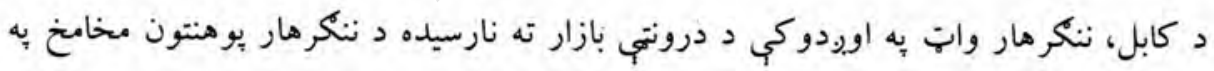
لويديخه برخه كي يوه جكه ستويه بنكاري جي د امر خيلو له ستوبي خخه عبارت ده او به به 


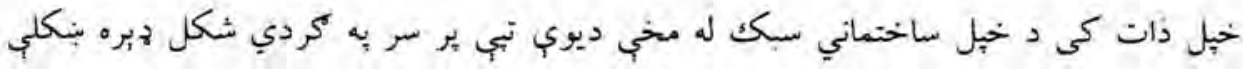
معلوميري جي كردنه يب له سيندنيو هبرو خخه او حخو كه يب به رواقي بنه تزينينكاري شوي ده. د مارانو غونليى: - n

ددرونتي به ساحه كى د بيمارانو به سر بيره د مارانو دتبي به نوم هم يوه يودايب سيمه شته ده

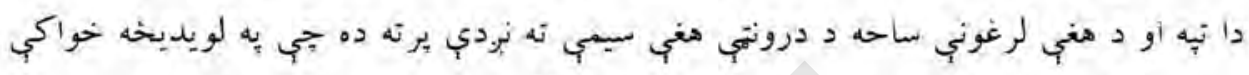

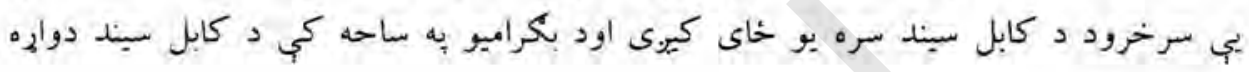
غإي بائيسيى

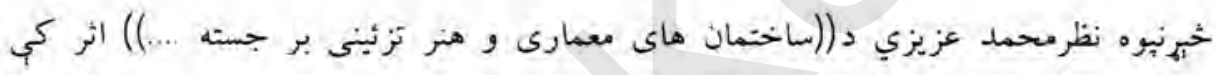

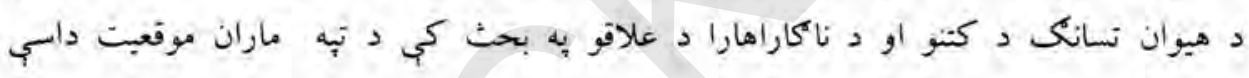
تصريتح كرى دئ

د نامكار د نسميي به برخه كي شيني بوهان به دي عقبده دي جي اساسا ((نكر)) هماغه

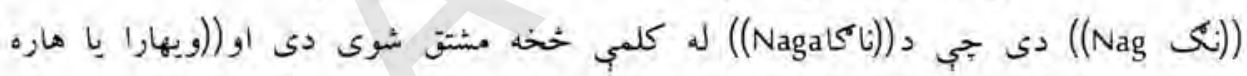
هماغه موى sعبد دى جي دسرخرود او د كابل سيند د مخامخ كيدو به شعال ختيخه

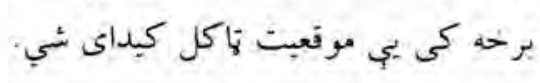

نو كه د مارانو د نيبي دا موقعيت سم وي. او لكه جي همدا اوس د كابل نسيند له بنى عإي خحخه بنكاري به هنه غاره كي دكيث تبه ده جي بر سر او لمنو كى او خه هم د بكرامي ستويبي

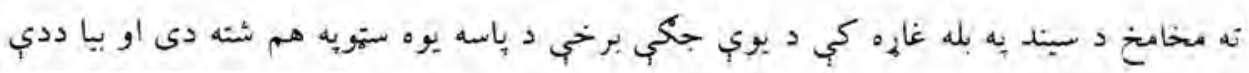
75

باستانشاسى افغانستان 
تبي به بيخ كى د سين به غاره زيات شمبر مغاري لكه د مجيو جكونه بنكاري، نو دا سيمه د مارانو د تبي خخخه عبارت ده.

$$
\text { او تري د باسه يو شمبر ستوبي شته دي }
$$

فيلخانه، د كوداره يا كودره توب، د بار رياط ستويه او د خواجه لاهور تيه:

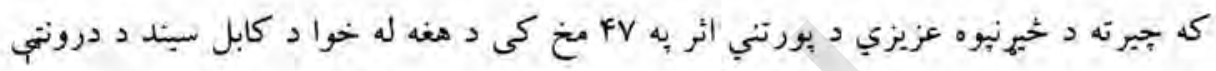

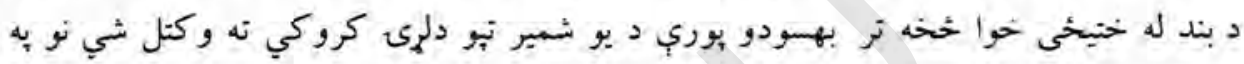
دي كي د بودايي د بوي مترا كمي سبمي به توكه يو شمبر غونليى ستوبي او سمخي ليدل

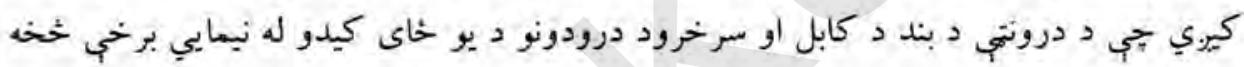
يب مبدا، به ترتيب سره به يوه مستفيمه كربنه د((كو داره ستويه)) وربسى فيلخانه، بيا يو شمير

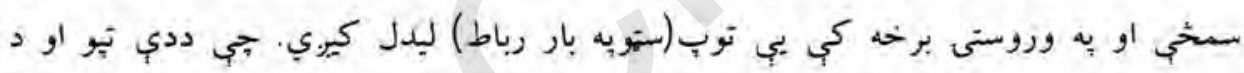

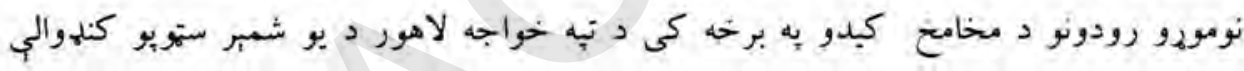

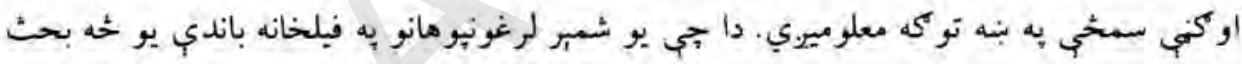

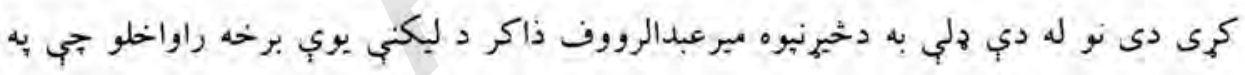

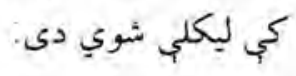

د درونتي فيلخانه ددي خاى به ختيخ او د كابل سيند به هغه غالجه كکى برته ده. همدارنكه دبناغلي غزيزى يه وينا فيلخانه به عمومي رول له يو زيات شمبر سمخو خخه تشكيله شوي ده جي به واقعيت كى د هنو راهبانو او مسافرينو استو كنحئ و جي د بودايي آئين بيروي يي غوره 
كري وه. او ددي آئين دزدهكيرو او بنوونو للاره به دلته راتلل او يوه موده يه يب به دي سمخو كي تيروله بجي به خيل وخت كي تولي بلستر او رنى آميزي شوب وي او د بودايب نقاشيو او

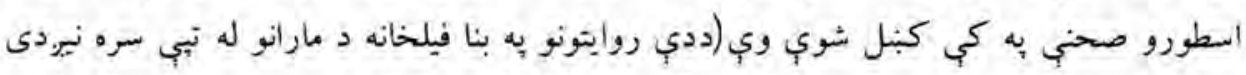

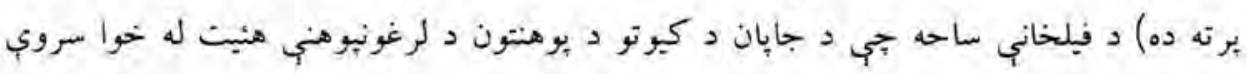

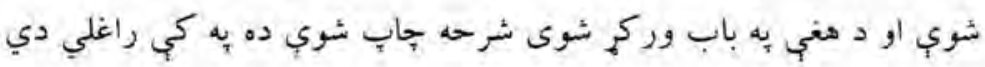
به فيلخانه كي د مهندسى او د كلالى لوبنو نوتهي و موندل شوي جي د شخلورمب او بنحمبي

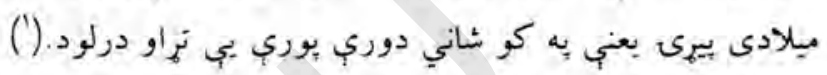
كه به بيخى مشخص هول وويل نّي دا بادي شوي سيمب د درونتي به خنيخ كى (اد حضرت

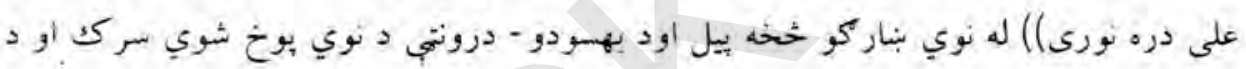

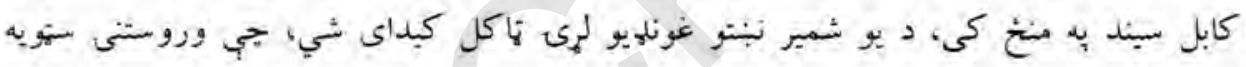

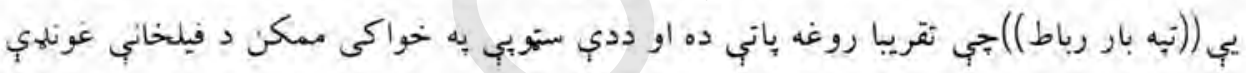

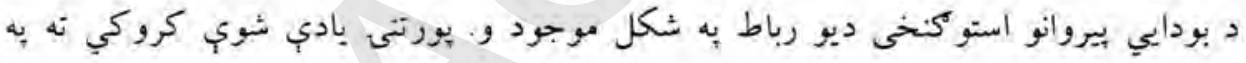

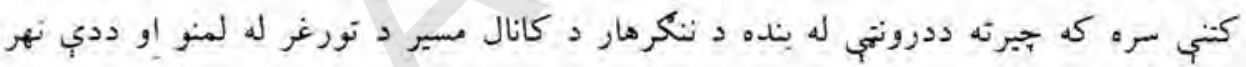

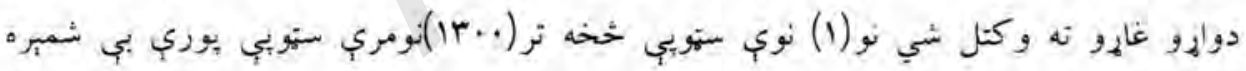

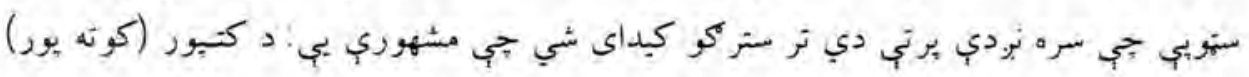

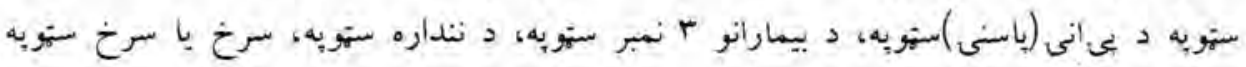

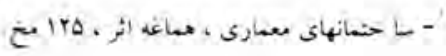


(دننداري ستوبي به مقابل كى)دده رحمن (1) نمبر ستوبه، د جان نتوب ه نمبر ستوبه او داسى نوري شته دي.

د ننداري له ستوبي خخه د كوشانيانو او ساكانو د دوري خيني آثار او د ((ده رحمن) له هـ

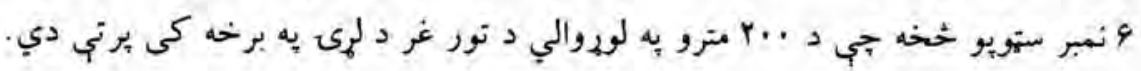

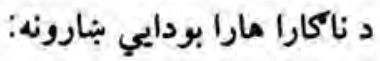

دجينى زاير هيوان تسانكى د ياديتتونو بر بنسيّن، نوموري به نا ـ كبي - موها (نكاراهارا) كى دغه بنارونه لبدلي او ثبت كري دي:

ديان كارا بودا DiponCarabudha

د لرغوني نكارا هارا له بودايي بنارونو خخه يو هم د يبانكارا بودا بناردى جيى د بودايي آئين

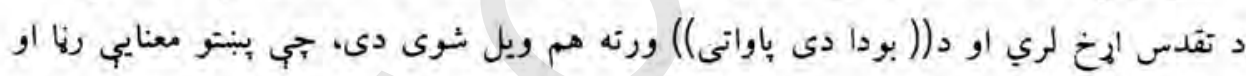
شعله ده دديبانكارا بودا دا بنار د زئد(زند)او د ماتسا زرتشت د مذهب يزوسينا به اعتبار هم د تقدس وريو بناردى او اوس يجي موفعيت معلوم نه دى.

$$
\text { yusi_ni-sa يوشى - نى يسا }
$$

دابنار به هوشى يشنك يعني د كلانو به بنار هم شهرت لري له دي بناره هيوان تسانكى او

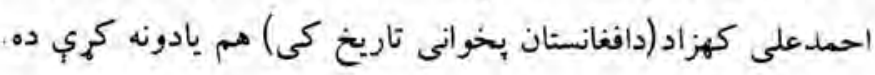


دا بنار جي به توصيفي لقب ياد شوى دى د ناكاراهارا د طبيعت د ستبتبكو مظاهرو جاتر بنه خلانده تعبير اود باغونو بنار (اغستان)يه نوم باندي هم معرفى شوى دى. خو موقعيت يي معلوم

Na_Ki ماكي (ناقى بنار)

د ناكاراهارا د مذهبي بنار به بخوانيو سر جينو كي د ناكي به نوم ياد شوى دى. يو شمبر خيمهونكي يي موقعيت د ناقي شيله (رودكى) او د جلال آباد بنارته نبودي بنيي. دممكن د بخوانى قند فابريكي به ساحه كي وي) هيوان تسانك وايي: جي د ديبانكارا بودا، هيليو او بري يوشى نى يشا بنارونه به نكاراهارا كي بخي كلا كاني دي جي دواكمنو د مركزونو به توكى

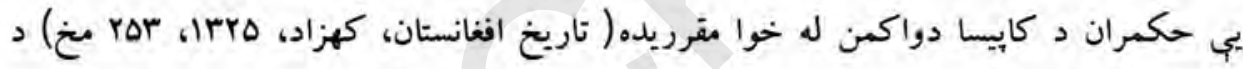
بناغلى عزيزى د ناكاراهارا د بنارونو د معرفي كولو به باب وايي: يو بل عالم د((سين مارتين)) به نوم د ناكاراهارا يا ((ناكاويهارا)) بنار ((اوديانا يورا)) بعني

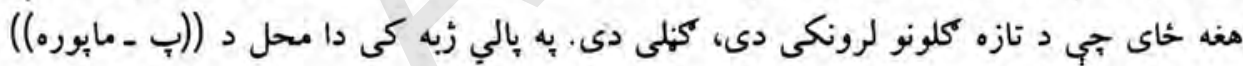

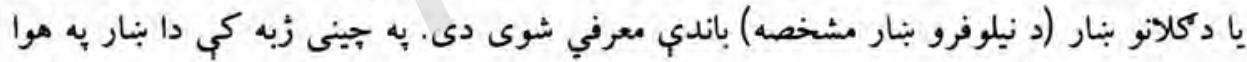

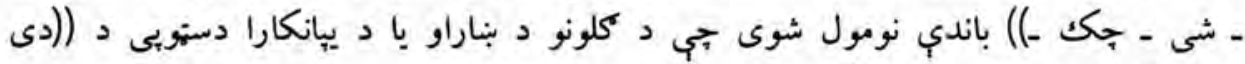

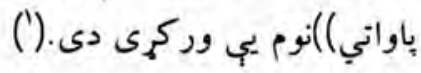

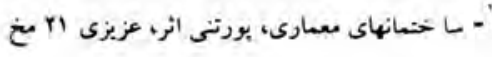


اـ اباسين، مطبع الله، لرغوني مبنه، مطبعه احمل، كابل، ITM كال . T- آريانا دايرة المعارف، تّ Y ، د دايرة المعارف رياست دعلومو اكادمى، نبراسكا مطبعه، كال.

r - رازقي نهيوال، دننكرهار لرغوني سيبي او تاريخي آثار، د بيهيقي كتاب خجرولو رياست

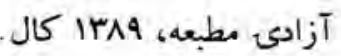

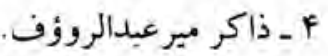

هـ عزيزى، نظرمحمد، ساختمانهاى معمارى و هنر تزئيتى بر جسته تِه شتر هده نامكاراهاراى

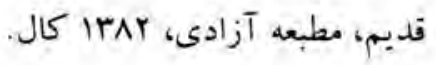

9 - عزيزى، آئار و ساحات باستائى مناطق جنوب و جنوب شرق افغانستان، IrM كال. V - كهزاد، احمدعلى، افغانستان د تاريخ به رنا كى، داورنكزيب ارشاد بيتّو زبإهن، دانش خيرندوية تولنه، يهبثور، IrV9 


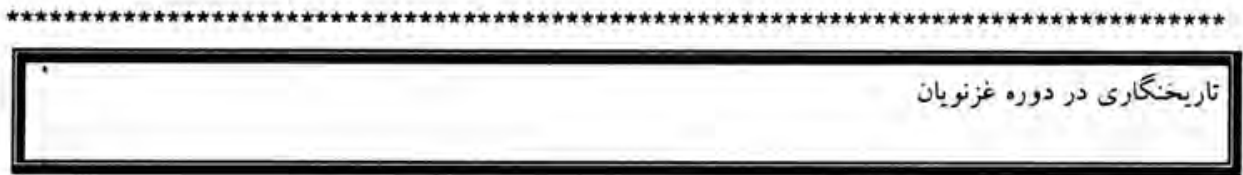

\section{معاون سرمحفن نور محمد (كاوهC}

تاريخنغارى در دوره غزنويان

مقدمه:

غزنويان بعنوان سلسله تركك نثراد با خاستگاه غلامى كه به هنگًام زوال و انقراض سلسله جون

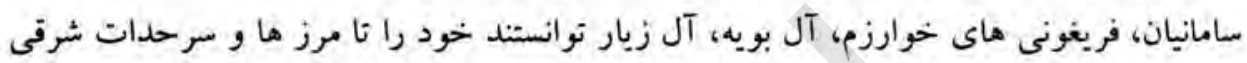
افغانستان (داخل سرزمين هند) با رهبرى يويايى و خردمندانه و شجاعانه سبكتگين سلطان

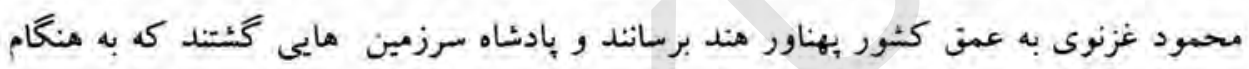

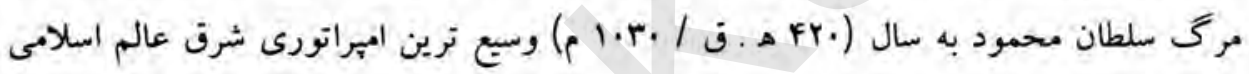
را بعد از تجزيه خلافت عباسيان تشكيل داده بودند.

سلطان محمود غزنوى و اخلاف او بمثابه طلايه داران فرهنگ ير غنا و تمدن با بر جاى اين مرز و بوم شناخته شده اند. بنيان گذار اين سلسله ترك نثراد نظر به شهادت منابع و ماخذ

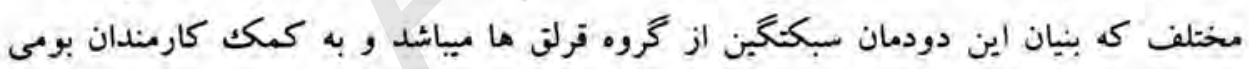
(كار كنان ديوانسالارى) خراسانى بعد بقدرت رسيدن خود را با رسوم حكومتى و تشكيلات

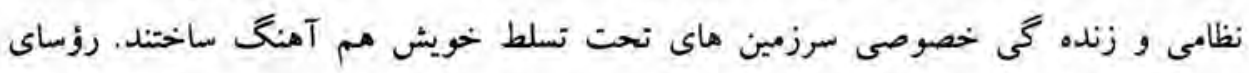

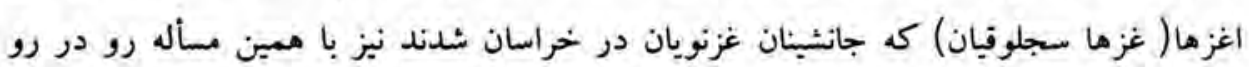
بودند، اما سلجوقيان در هم ساز نمودن خود با اين رسوم نوين كمتر موفقيت داشتند، از يك تكريك طرف و از جانبى هم سلطان مسعود كه خراسان را از دست داده بود، اما اعقاب وى توانستند 
تا يكت قرن ديخر در قسمت هاى شرقى افغانستان (هند) بحيات سياسى، نظامى و فرهنى خويش ادامه دهند

بنأ خراسان بمثابه تخته خيز ساير كثور ها از بكت جانب و از جانبى هم غزنى بحيث مركز

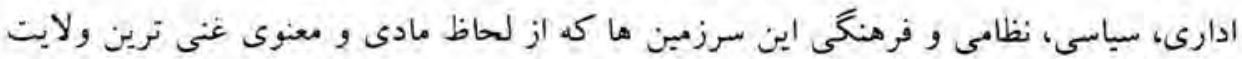
اين امبراتورى به شمار ميرفت و از همين جهت مياشد كه در اين برهه زمانى در مورد ابئ

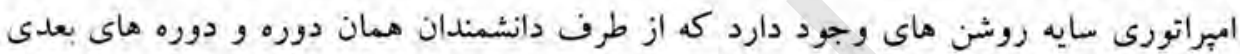

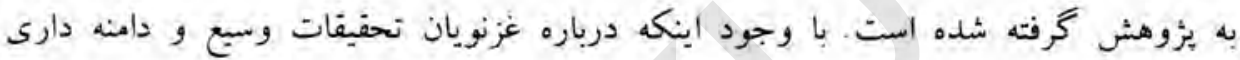

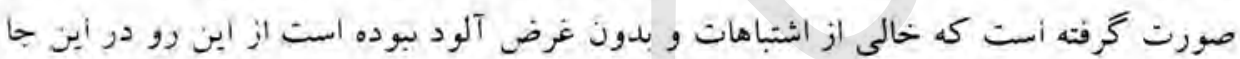

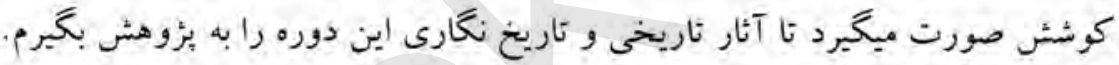
اما قبل از همه لازم مى افتد كه راجع به مفهوم تاريخ نغارى معلومات بدست آوريم بناً كمى در اين مورد به بحث مى بيردازيم

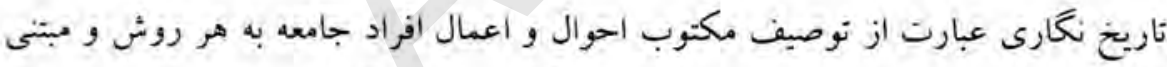

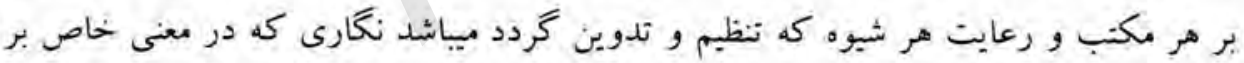

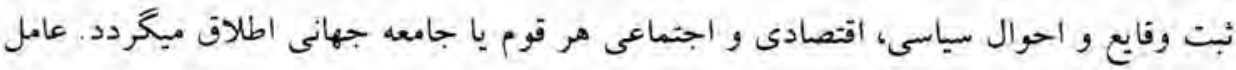

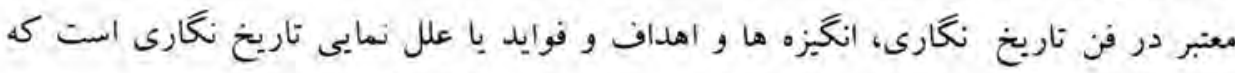

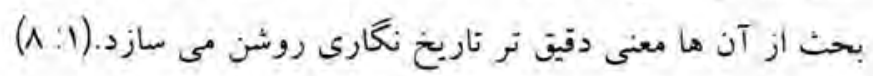


اكنون مى يردازيم به بورسى تاريخ نويسى و تاريخ نخارى در عصر غزنويان بناً جهق سهولت و آسانى كار و يثروهي درست آثار اين دوره و دوره هاى معاصر اين خاندان راقرار ذيل به ششي دوره تقسيم ميكنم: ولى هشدار ميدهم كه بورسى در مورد أين شش دوره درين مقاله بصورت مفصل كنجايش ندارد بنأ كوشش شله است كه بصورت مختصر آن ها ران به معرفي بـكِرم

ا- تاريخ هاي عمومى و دوج2 مان هاى شاهى و وقايع نامه ها.

$$
\begin{aligned}
& \text { r- تواريخ محلى } \\
& \text { r-r زنده گ نامه }
\end{aligned}
$$

F - آثاريكه در باره ادب و آداب الملوكت ها وغيره تاليف شده است

ه- كتابهاى جغرافيا و سفر نامه ها.

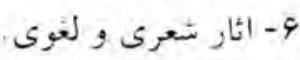

\section{ا- تاريخ هاى عمومى و دومانهاى شامى و وقابع نامه:}

از منابع غرويان، قديمى ترين آثار تاريخ بمينى ميباشل در ستايث جهانكثايى هاى سبكتكيث و نسلطان محمود عزنوى تسوسط ابسونصر محمـد بن غبدالجيار غتبى ( دركذشت

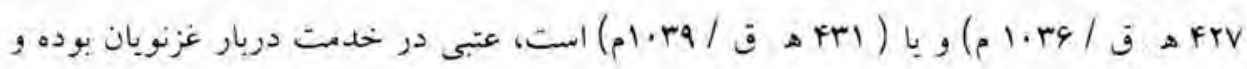
نام كتأب حود را لقب سلطان محمود عزنوى يمين الدوله بنام (تاريح ميمينى) كذاشته استـ ور

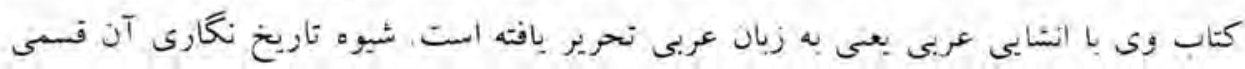




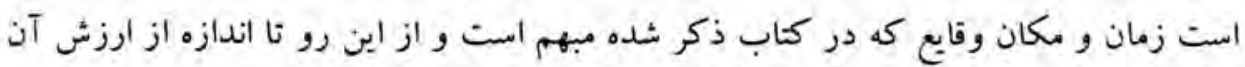
كاسته شده است، مؤلف به بخئ هاى غربى اميراتورى غزنويان بيشتر از هند علاقمند شده

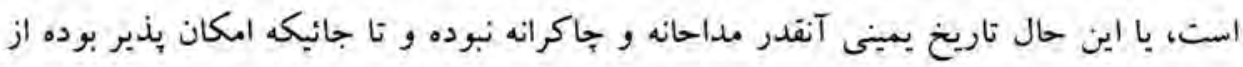

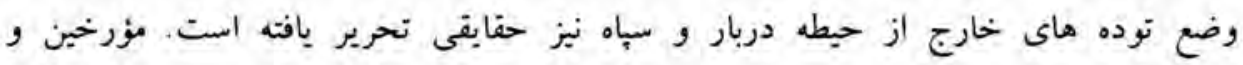
برؤهشخران بعدى هم از اين اثر استفاده نموده اند.

ترجمه تاريخ يمينى مشتمل است بر وقايع تاريخى از اواخر سامانيان تا روزگار سلطان

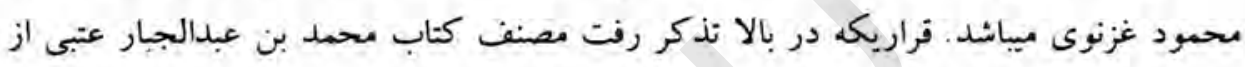

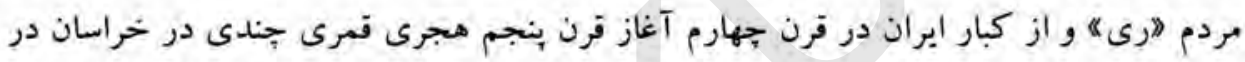

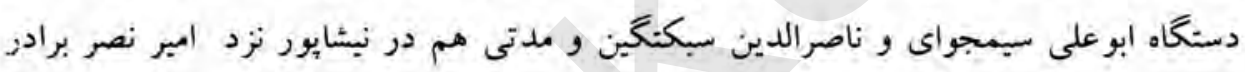
سلطان محمود به سر برد، وى در كتاب خود از غزوات سلطان محمود غزنوى در هيد از فييل

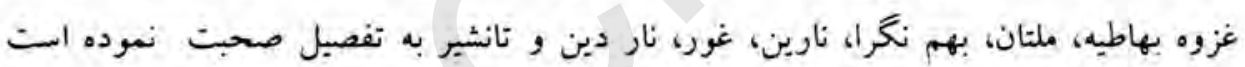
جنانجه فسمى بنداشته ميشود كه نويسنده مذكور فدم به قدم بدنبال سلطان غزنه رفته است،

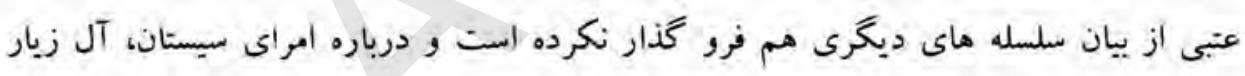

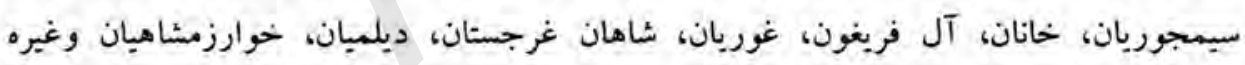

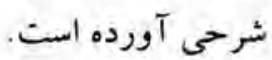

از اين رو اين كتاب يكى از ماخذ هاى عمده و شايان توجه به شمار مبرود و نزد درى

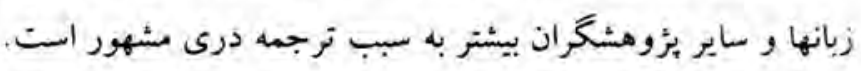




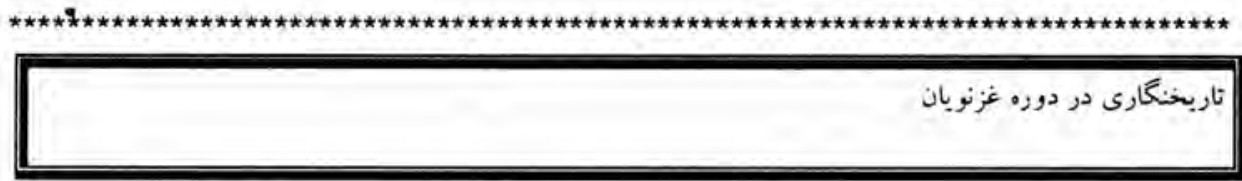

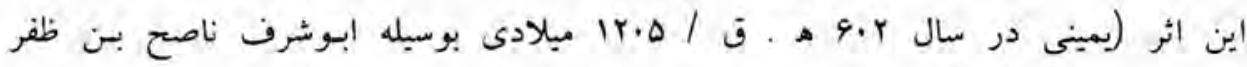

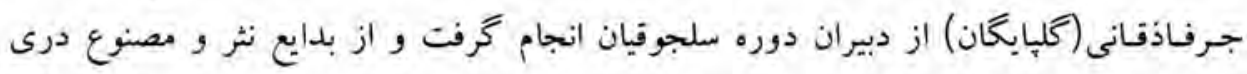

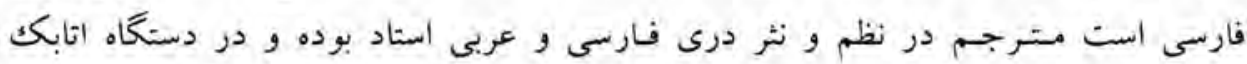

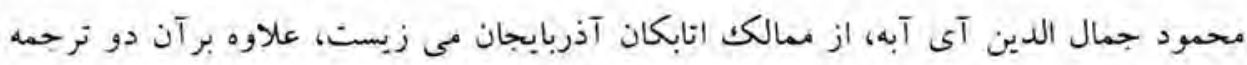

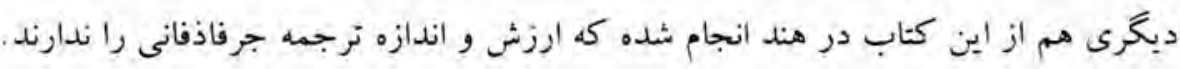

جنه ادبى ترجمه تاريخ بمينى ههم است، جنانجه ملكت الثعراى بهار آن را بس از نثر

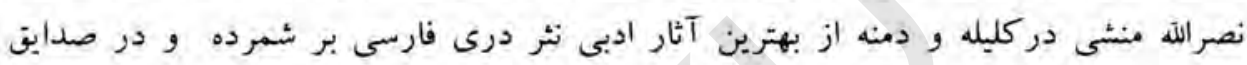

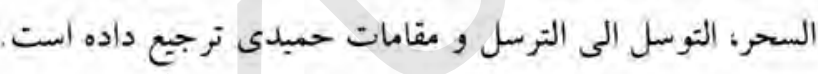

در اين اثر از مسايل كروناكون مذهبى، اجتماعى مطالبات سودمند تذكر رفته كث از طرز

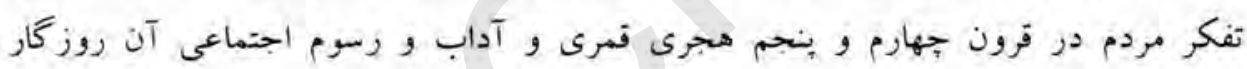

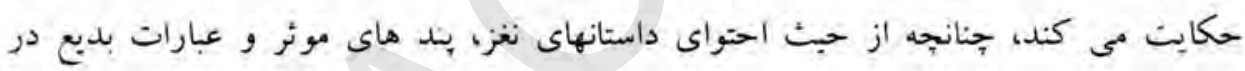

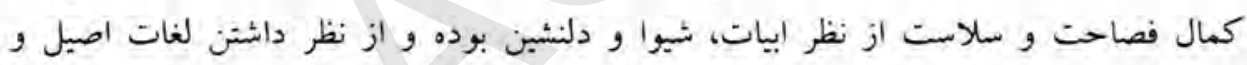
استعمالات خاص و نكات دستورى اهميت بسيار داد. نسخه فعلى ترجسه تاريخ يمينى سه بيوست فرار ذيل دارد:

1- خاتمه تاريخ يمينى با حوادث ايام (اواخر فرن ششم) به قلم جرفاذقانى، كه نويسنده به

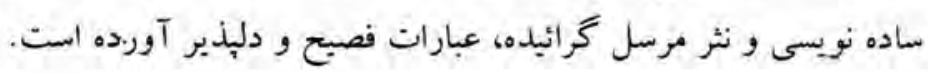




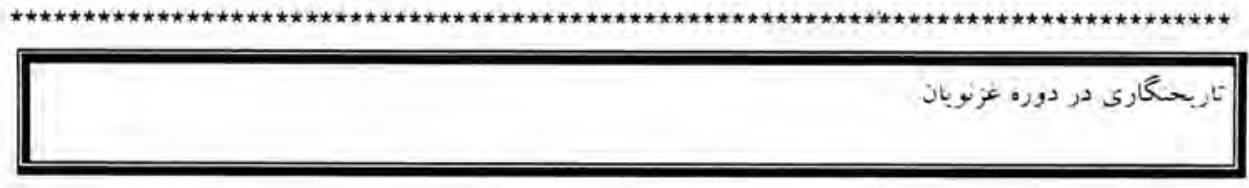

ب- آخر تاريخ يمينى كه مترجم آن اسماعيل سكزى است و ترجمه خود را در نيمه اول قرن هفتم هجرى قمرى انحام داده است. r- تر جمه مرئه أمير نصر بن ناصر الدين سبكتخين ترجمه تاريخ بمينى در سال Irov خورشيدى به تصحيح جعفرى شعار در تهران نشر شده.

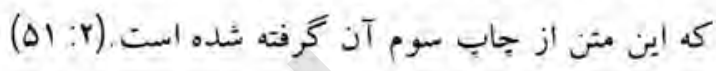

دومي اثر مهم و با ارزش كه در دوران غزنويان به رشته تحرير در آهده است. زين

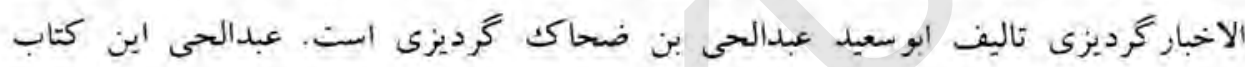

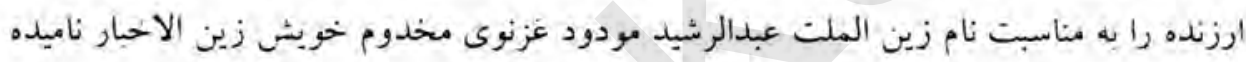

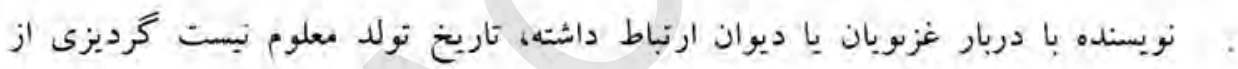

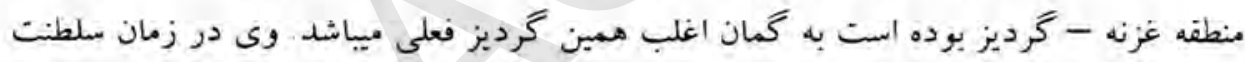

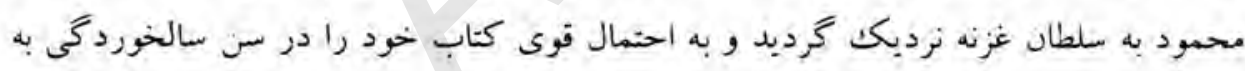

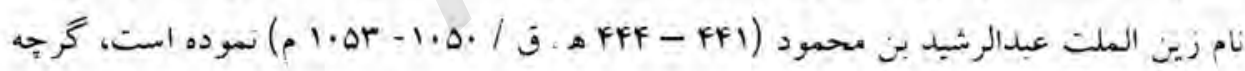

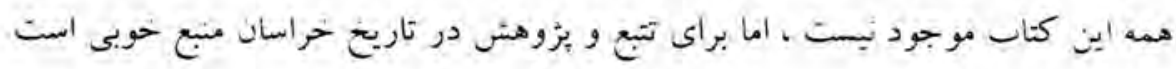
منابع مورد استفاده گرديزى درباره تاريخ بيش از غزنويان وكزارشهاى وى از اعمال و

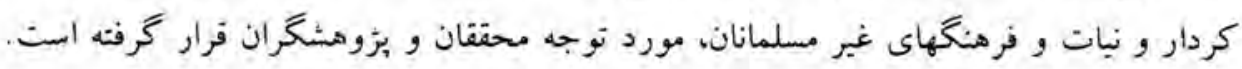


از همه مهم تر استفاده وى از تاريخ ولايات خراسان نوشته ابوعلى سلامى است كه تا اكنون بيدا نشده است، سلامى خود مورخ و شاعر نيمه دوم قرن هجرى قعرى از نزديكان ابوبكر

$$
\text { هحمد بن محتاج و فرزندش ابوعلى جغانى بوده است.(r: 1ry) }
$$

گر ديزى اطلاعت خود را درباره علوم آداب و سنن هندوان از كتاب جيهانى استفاده

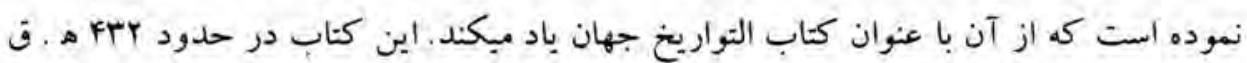

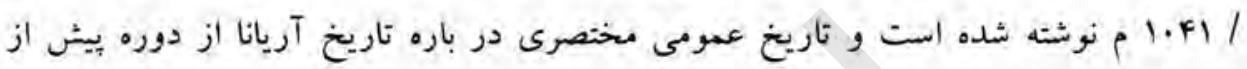
اسلام تا عصر نويسئده است

قراريكه از تاريخ نكارى و تاريخ نويسى گرديزى معلوم ميشود، اقتباس و تقليد گرنه از آثار البافبه ابوريحان بيرون است كه در آن به تاريخ عمومى اسلام و سرزمين ما بس از أسلام عنايت بيتتر شده است و به سبب اشتمال بر اخبار فديم خراسان حتى در مواردى كه ماخذ ديخر غير از كتاب سلامى در اين باب بهره برده اهميت خاص خود را دارا ميباشد. اين كتاب بردي

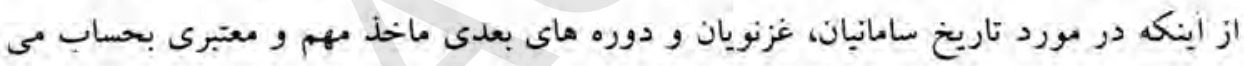

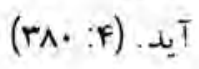

اثر بى ثظير دبخريكه به شيوه نحاص تاريخ نغارى در عصر اول غزنويان برشته تحرير در

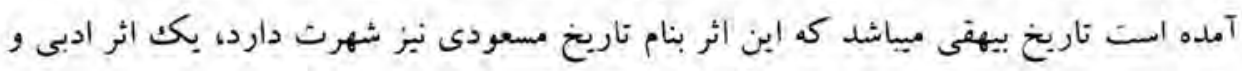

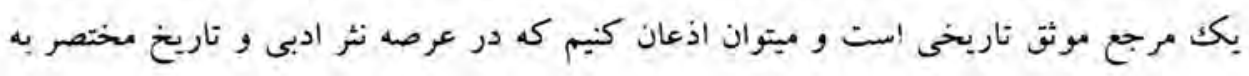




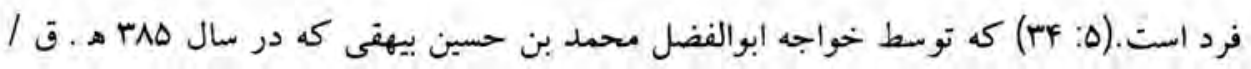

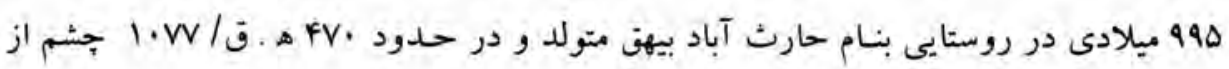
جهان بوشيده است.

بيهى دبير فاضل در دوره اين سلاله بود، تحصيلات أوليه اش در شهر نيشابور ميباشد و

بعد از اتمام تحصيل و كسب فضايل به ديوان رسالت محمود غزنوى راه يافت و آنجا شاكرد دير زير دست خواجه ابونصر مشكان رئيس ديوان بود و به استاد خويش خيلى نزديك شد تا

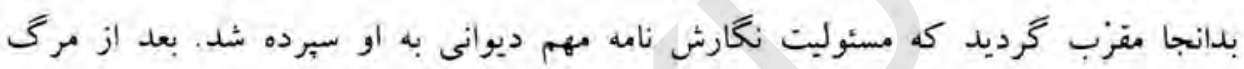
ابونصر مشكان و انتصاب بو سهل زوزنى برياست ديوان رسالت بيهقى، همجنان بجاى خود باقى مائد و با ناسازگارى بوسهل، مدارا كرد و در حقبقت ديوان رسالت را در اين دوره او بوري

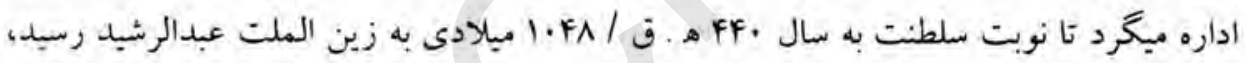
مدتى به مقام رياست ديوان را بدست كرفت ولى بس از جندى دجار دسته بندى ها و سعايت

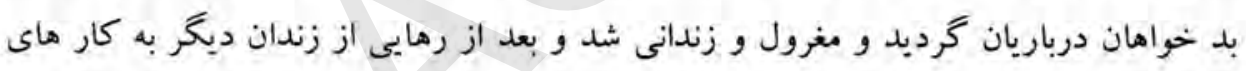
ديوان نبرداخت

تاريخ بيهى يا تاريخ مسعودى مشهور ترين تاريخ بزبان درى فارسى ميباشد كه بر علاوه

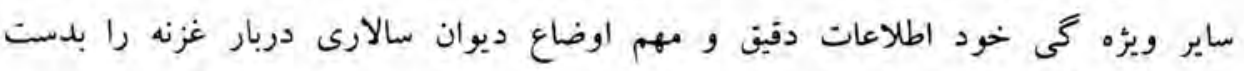
ميدهد.(9: ه) اين اثر مهم ترين تاريخ نامه و از استوار ترين و دلنشين ترين آثار متثور فارسى درى بشمار ميرود، اين كتاب علاوه بر تاريخ غزنويان و اطلاعات خوب و دقيق درباره 
فرمانروبان صفارى، سامانى، آل بويه، آل زيار حاوى معلومات در مورد دستگاه خلافت بغداد و بويثه آغاز كار سلاجقه است.

افزون بر آنجه كه تذكر داديم نكات بسيار دلجسب درباره اوضاع داخلى دربار و روابط درباريان و زد و بند و ستيزه هاى بنهان و آشكار وزيران و ديوانهاى و امرا و بدران و بسران اهميت خاصى دارد. بيهقى يخانه كسى است كه معنى تاريخ را دريافته و قصدش تدوين داستانهاى جنگ ها و فتوحات نبوده بلكه كوشيده است، آكاهانه و از روى صدث و بيطرفى از راز حوادثى سخن براند كه از آن فوايد مورد نظرش حاصل شود. او در اين كار شرط لازم در تاريخ نگارى از جمله دقت و اطلاعات و امانت و نقد منابع اسناد و ديدگًاه هاى بيطرفانه نسبت

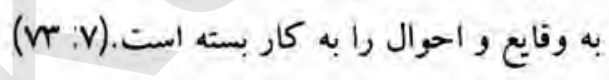

اين كتاب از لحاظ مسايل تاريخى در كمال صحت و دقت است و از لهاظ اسلوب نغارش در حد جمال و ظرافت جنانجه با همه لغت هاي عربى، حتى جمله هاى دراز عربى و فروانى اشعار عربى باز هم نثر كتاب روان و دل انغيز است. دوره كامل كتاب سى جلد بود اما آنجه از حوادث روز مار تا كنون بدست آمده همان است كه موجود است و متباقى آن از بين رفته است، از بخش باقى مانده نويسندگانى جون منهاج سراج، عوفى، عقيلى و حافظ ابرو استفاده نموده اند. اين اثر را نخست بار سيداحمد مشهور به اديب يشاورى تصحيح و جاب كرد و سعيد نفيسى آن رادر سه جلد جاب نمود. 
r - تواريخ محلى در عصر غزنويان نوشتن تواريخ محلى بخصوص حر قسمت هاى شرقى جهان اسلام رونق زيادى داشت تاريخ محلى را بنام تاريخ ولايتى لا تاريخ شهرى نيز بادي

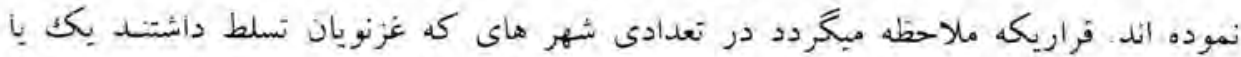
جند ثقر مورخ محلى يا ولايتى را برورش داده بودند.

تاريخ ولايث خراسان كم اكنون در اثر حوادث تاريخى أز بين رفته و توسط مورخ و شاعر جبره دست ابوعلى الحسن اسلامى در اواسط قرن (جهارم هجرى قمرى / دهم ميلادى) برشته تحرير در آمده بود، در زمان خويش از شهرت خاصى برخوردار بود اين اثر در محيط واليان

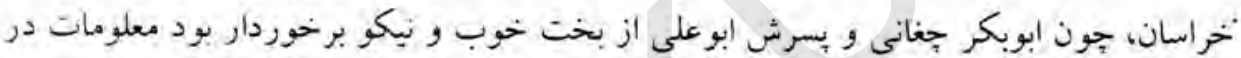

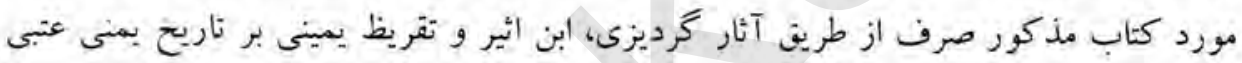
بدست مورخين معاصر رسيده است. اثر ديخريكه در رديف تاربخ محلى يا تاريخ ولايتى قرار

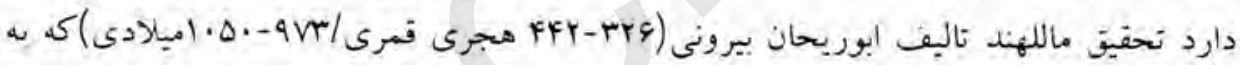

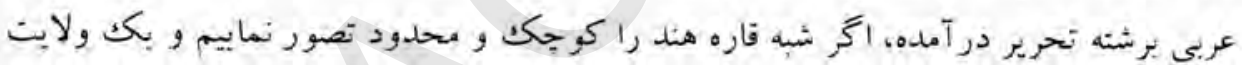
يا ابالت فكركيم، ميتوان آنرا تاريخ محلى خواند ماللهند اطلاعاتى خوبى در مورد فرهنى

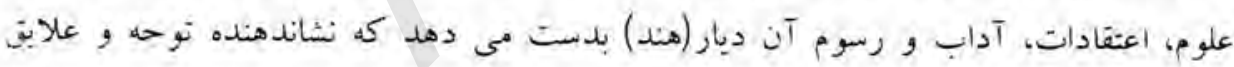
خاص بيرونى به همه خلاقيت ها، دست آوردها و مظاهر انديشه و تفكر انسانى در ائ سرزمين ميباشد

فتوحات و نفوذ سياهيان غزنويان به سرزمين هند موجب ديدار البيرونى از هند كرديد، ابن

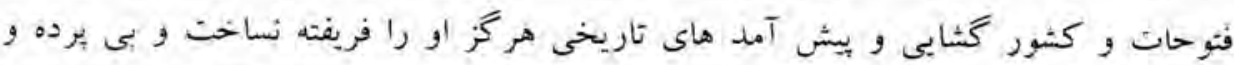


آشكار تمام ويرانى ها و خرابى هاى ناشى از اثر اين جنخ ها و لشكر كشى سلطان محمود

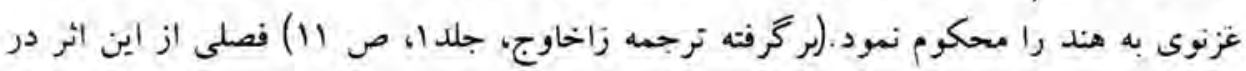
مورد سلاطين هندوشاهان كابل است.كه در مورد تاريخ منطقه، يش از ضميمه شدن هند به قلمرو غزنويان و در روشنايى قرار دادن تاريخ سلاله ير اهميت هند در دوره غزنويان و بسا موأرد ديخر كه ميتوان از آن سود جست، همانا تاريخ ماللهند تاليف البيرونى ميباشد. تاليفات ديخر البيرونى عبارت اند از اثرى بنام المسامره فى الاخبار خوارزم كه تاريخى است ازئ زاد كاهئ

از ولاياتى كه در ساحل كرانه جنوبى بحيره كسيين واقع اند نيز تعداد زيادى مورخين محلى برخواسته كه يكعده آثارى از ايشان به نشر رسيده كه در مورد مئاسبات زياريان دوره هاى اخير با سران و اختيارداران غزنويان معلومات مفيدى بدست مى دهد كه از جمله ميتوان از بران تاريخ جرجان يا تاريخ معرفة العلما و اهل جرجان، تاليف حمزه بن يوسف سهمى (متوفاى بهري

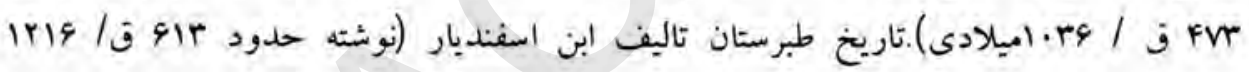

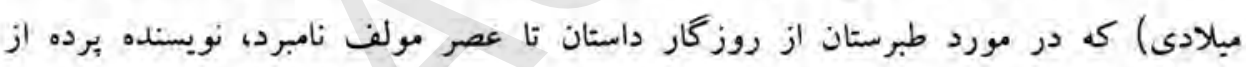
دودمانهاى محلى برميدارد. ظهيرالدين مرعثى گيلانى نيز تاريخى بزبان درى فارسى در مورد

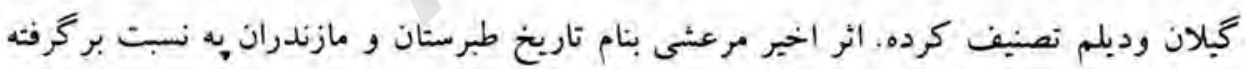
از كتاب اسفنديار در مورد مناسبات زياريان با غزنويان دنباله كار اسفنديار است.

تاريخ سبيتان نيز به نسبت ثبت و نقل تاريخ دوره اول غزنويان از اهميت خوبى برخوردار

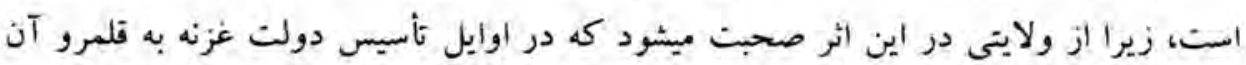




\section{تاربخنغارى در دوره غزنويان}

ملحق شده بود. مولف آن مجهول است، اثر در ابتدا به عربى نوشته شده اما در عصرسلجوقيان به درى فارسى برگر دانده شد.

تاريخ نيشايورى تاليف الحاكم ابو عبدالله محمد نيشا يورى محمد شاه معروف به ابن البيع نيز از جمله تاريخ هاى محلى ميباشد كه شامل هشت يا دوازده جلد بوده اين كتاب زندكينامه علماى محلى تا سال .یr ق/.99 ميلادى با فصلى در باره تاريخ و جغرافيا بايان مى يابد. مولفان بعدى نظيرى سمعانى ياقوت و ابن جوزى وسيعاً از تاريخ نيشايورى ابن البيع استفاده

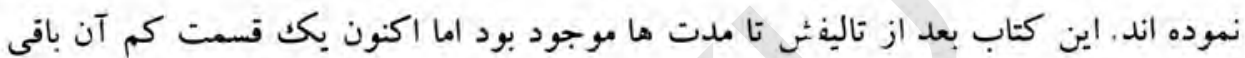
مانده است.

r - زندگينامه ما: بخش سوم تاريخ نغارى در مورد تاريخ غزنويان در منابع اسلامى بيشت آثارى كه نوشته اند شرح احوال و زندگينامه ها است كه يكت بخش در مورد عقيده و مذهب سخن رفته است جنانجه اين آثاـ به شرح احوال شافعيان و حنبليان برداخته اند و از جانبى هم به تقدس و ستايش شخصيت يا رفتار فردى واحدى مي بردازد كه در مورد دوم جهره واقعى شخص مورد نظر زير ستايش نازوا و نا معقول يا اعمال غير قابل و كرامتهاى نسبت به او ينهان ميشود كه نمونه اين نوع آثار در اسرارالتوحيد فى مقامات الشيخ ابوسعبد تاليف محمد بن المنور است كه زند گينامه يكى از عرفاى بزرى خراسان عصر غزنوى مباشد.

F- T- ار راجع به ادب و آداب الملوك ما:- اين نوع آثار براى خاورشناسان ومستشرقين از ممان آوان تاكنون داراى ارزش مهمى ميباشد زيرا كه در اين نوع آثار اصول اخلاقى و نمونه 
هاى از رفتار ميان مسلمانان با فرهنگ عالى به ايشان ميدهد. يكى ازين نوع آثار بنام مفاتح العلوم تاليف ابوعبدالله محمد بن يوسف الخوارزمى ميباشد كه در نيمه دوم قرن جهارم

قابوسنامه اثر ديخريست كه كيكاوس بادشاه مافبل آخر دودمان زيارى گركان و طبرستان در سال هV FV ق /rم•اميلادى آناز نموده، اين دودمان كث در حقيقت از همان آعاز خراج گذار غزنويان بودند و خود كيكاوس خود جند سالى در دربار سلطان مودود بن مسعود كذرانده بود ازين سبب به سياست ها و اخلاق شان با نظر تاييد مينخرد.

ه - كتب جغرافبا و سفرنامه ما:- آثار مهم و با ارزشيكه در عصر غزنويان برشته نحرير

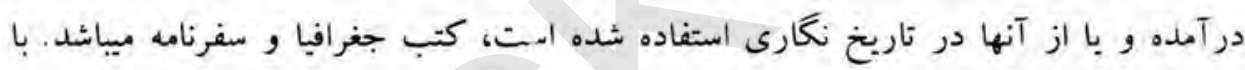
وجود اينكه اين آثار از جمله آثار.كرانبهاى أست كه از آنها در قرون متمادى استفاده صورت كرفته، كه جند دهه فبل يا بعد در كثورهاى اسلامى نوشته شده است. اطلاعات جغرافيه نويسان درباره شرح اوضامٍ و احوال، بالاخره ارتبا.ب!ت، زندگى اقنصادى، رسوم محلى و

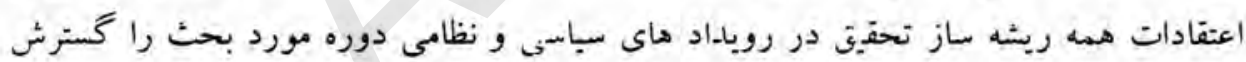
ميدمد، جغرافيا دانان عرب فرن جهارم هجرى قمرى نظير اصطخري كه تاليفش را در سال ( TFF.)

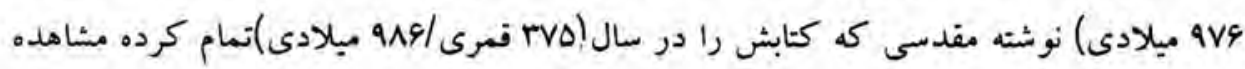

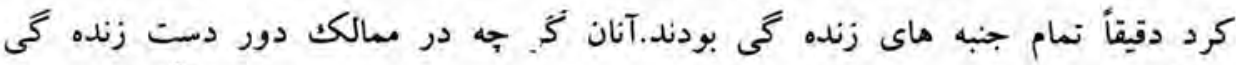

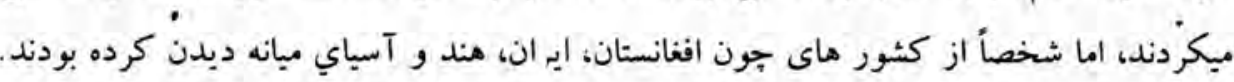


جنانجه مقدسى اطلاعات وسيعى را در احسن التقاسبم درج نموده، اين اثر را از تاليفات مهم جغرافيايى بحساب آورده اند

ه- آثار شعرى و لغوى:- عصر غزنويان دوره شكوفايى شعر و ادب درى فارسى و عربى است، سلطان محمود و سلطان مسعود أز جمله شاهانى بودند كه توجه خاصى به شعر و شاعرى

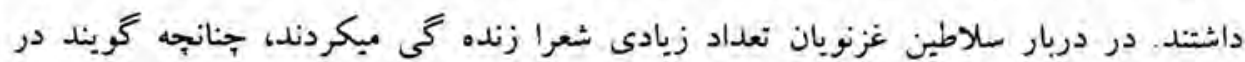

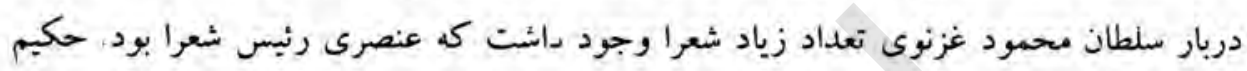
ابوالقاسم فردوسى بزرگترين اثر خويش را بنام ثانانامه فردوسى در دربار سلطان محمود تعرد غزنوى بيايان رسانيد، شعراى ديخريكه درين عصر زنده گیى داشتند عبارت بود از عسجدىى، بردي،

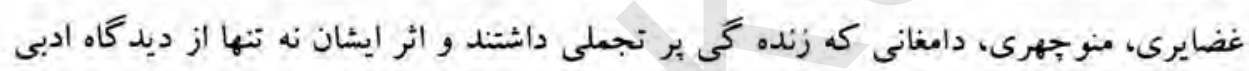
بحيث آنار گرانبها بحساب مي آيند بلكه نزد مورخين نيز از اهمبث بسزايى برخوردارند زيرا

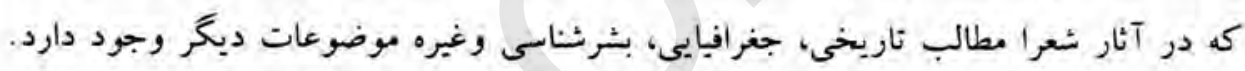
بدين منوال در آثار نثر ادبى نيز مطالب تاريخى و ساير مطالب وجود دارد.

\section{نتيجه}

شكست و اضمحلال بكك اميراتورى بزرى احيل تاجك (سامانيان) نتيجه يك سلسله ناكامى هايى بود كه در اثر سازش و اعتماد و دمسازى عناصر نو ظهور غلامان، باعث آن شد

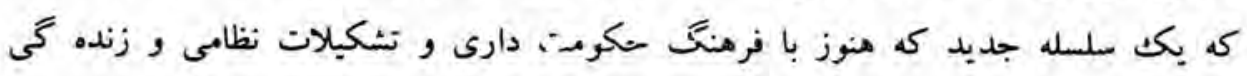
خحموصى در سرزمين افغانستان سأير كثربر ها هماننخ ور آشنا نبودند، اما بعد ها با كمكك

\section{4}


$\star \star \star \star$

تاريخنارى در دوره غزنويان

كارمندان و كاركنان ديوان و ديوانسالارى توانستد كه با يكت حركت قهرمانانه و مدبرانه كه

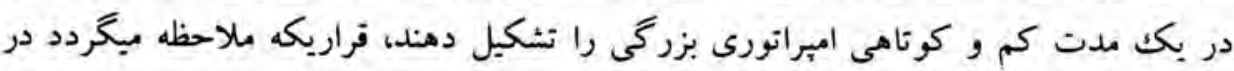

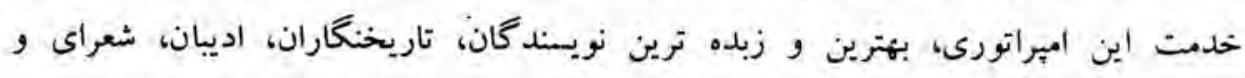

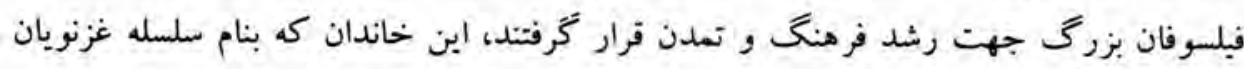

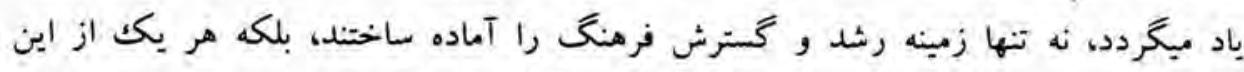

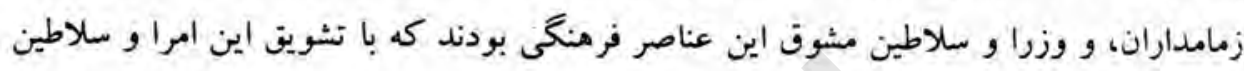

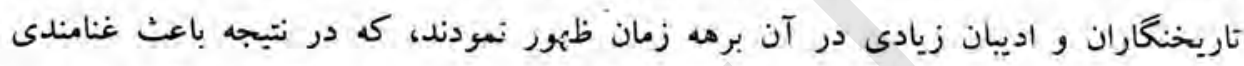

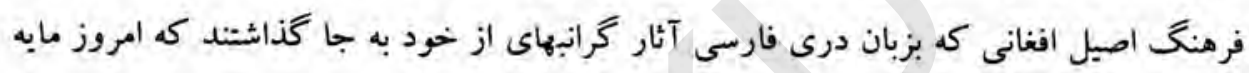
افتخار اين مرز بوم ميباشد.

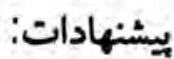

آز آنجائيكه شهر غزنى بحيث مركز تمدن اسلامى در سال rا.ب از طرف يونسكو

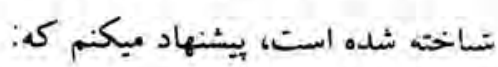

1- شهر غزنى بمناسبت همين نام و عنوان به يكث شهر مدرن با سبكت معطارى دوره

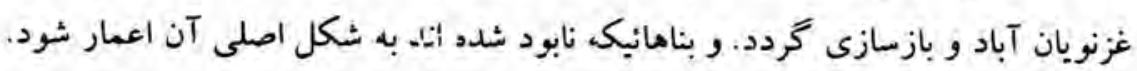

r- بيشنهاد ميكردد كه اكادمى نظامى كابل بناخ اكادمى نظامى سلطان محمود غزنوى و يا

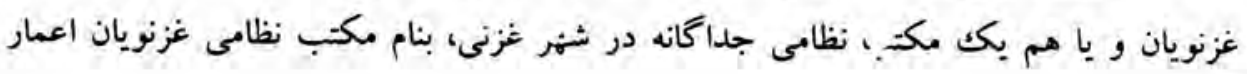




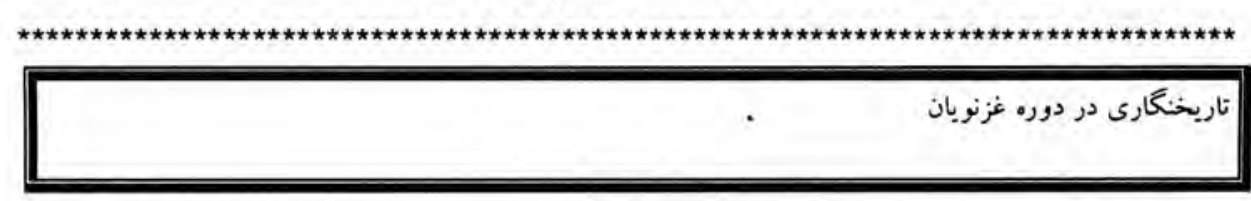

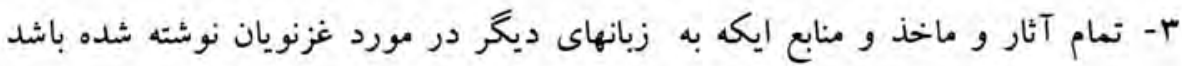

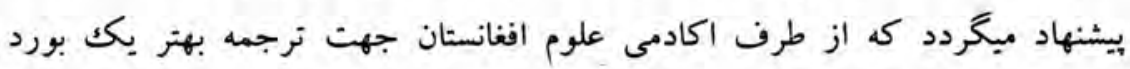

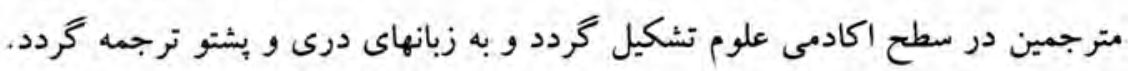

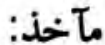

|- باسورت، ارنولد كليفورد، تاريخ غزنويان، ترجمه: حسن انوشه، تهران: امير كير، هAr|. Y r رضوى، محمدتقى، مدرس، مقدمه بر تاريخ بخارا نرشخى، تهران: نشر (سمت) IrهI. r- سجادى، سيد صادق، هادى عالم زاده، تاريخ نغارى در اسلام، تهران: (سمت) •^rا. F- عتبى، عبدالجبار، تاريخ يمينى، ترجمه: ابوالثرف ناصح بن ظفر جرفاذفانى

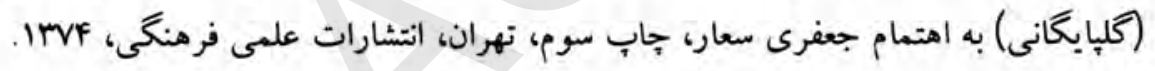
ه- محمد، متون تاريخى بزبان فارسى، تهران: انتشارات وزارت فرهنى و ارشاد، IVV9. 9- نوابى، عبدالحسين، متون تاريخى به زبان فارسى، تهران: نشر (سمت) سال ITV9. V- V - Vمان اثر صفحه. 


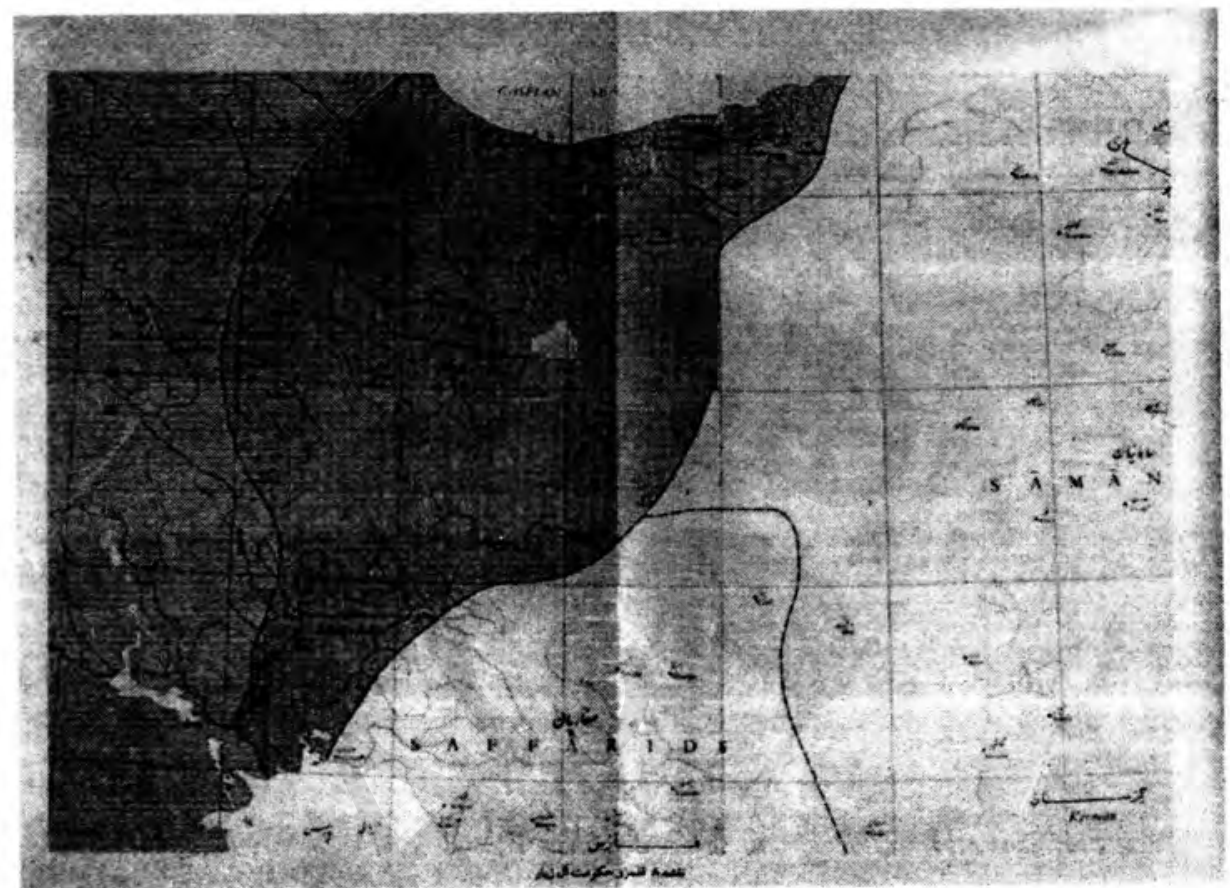



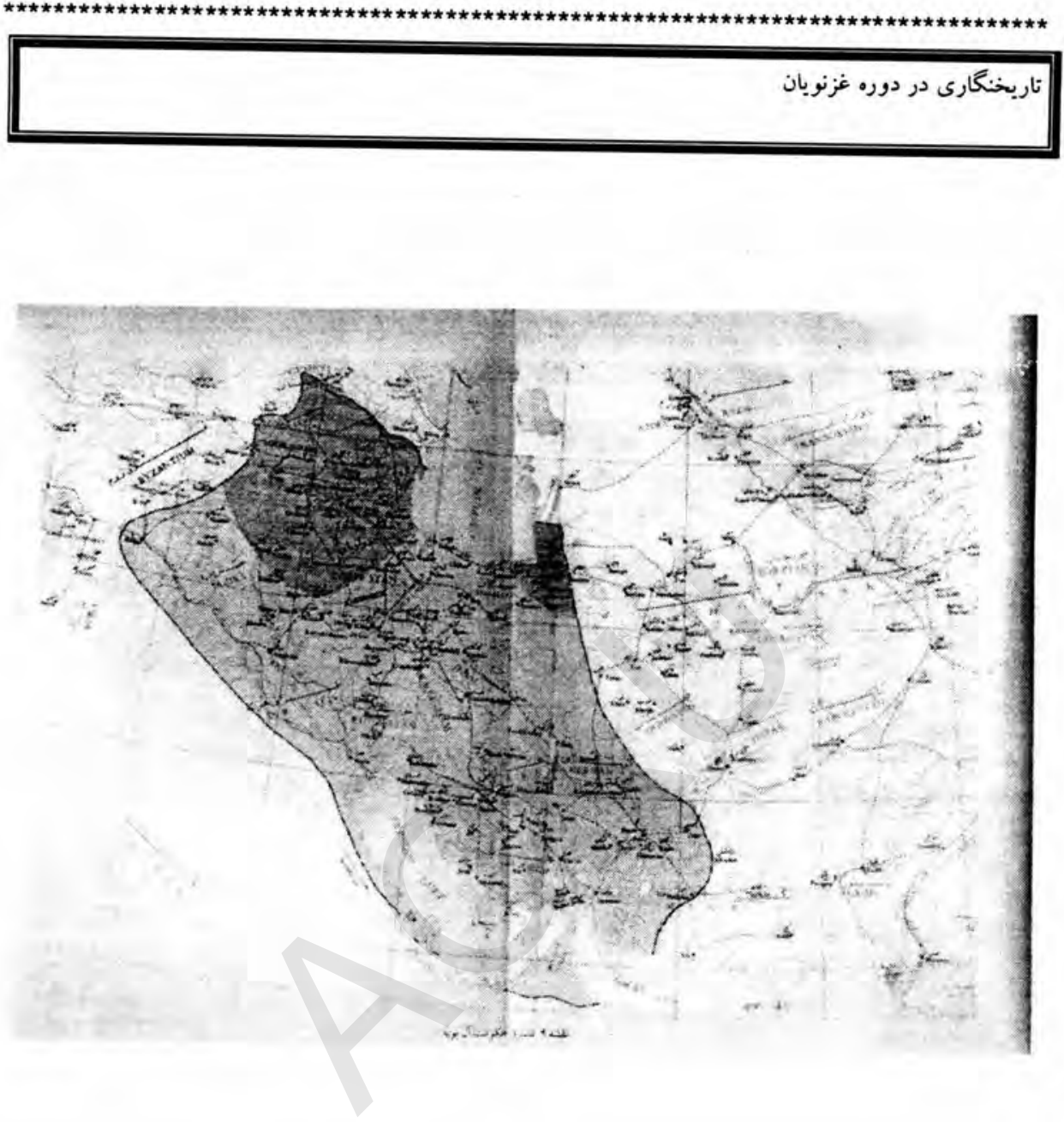


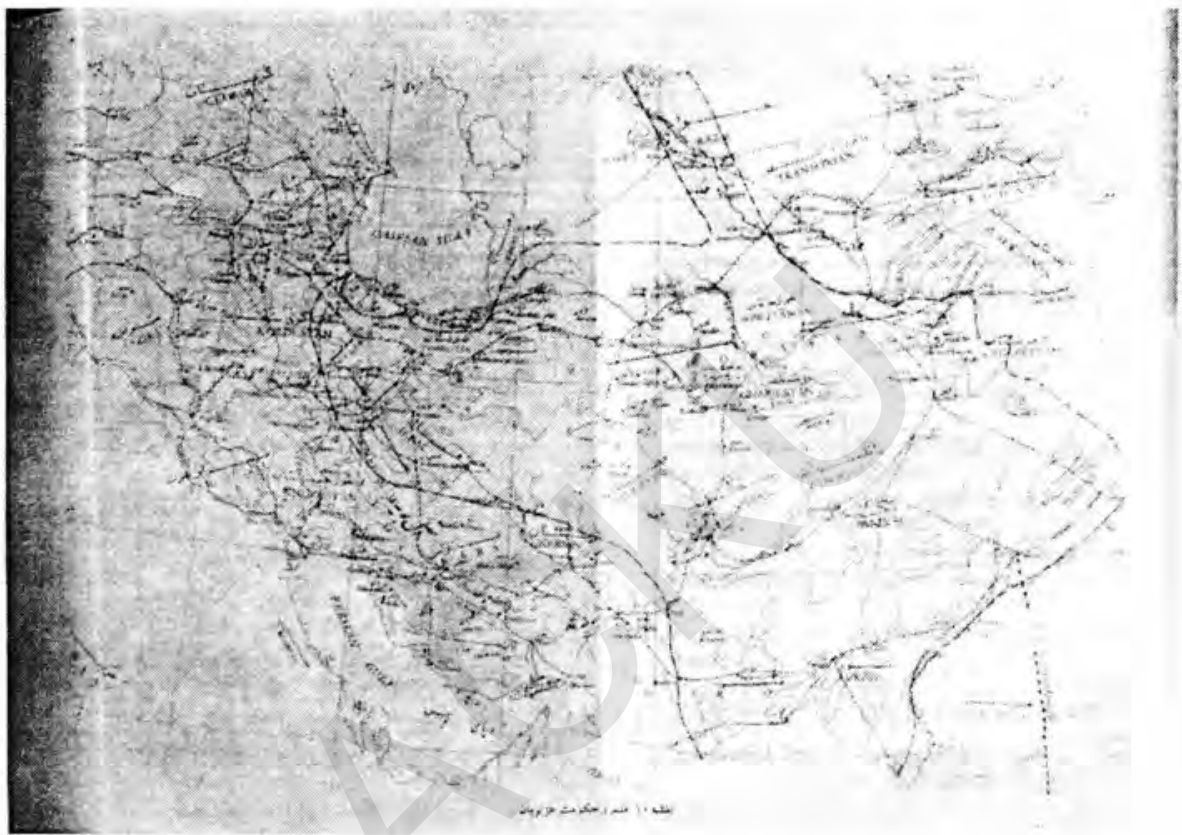


تاربخنكارى در دوره غزنويان
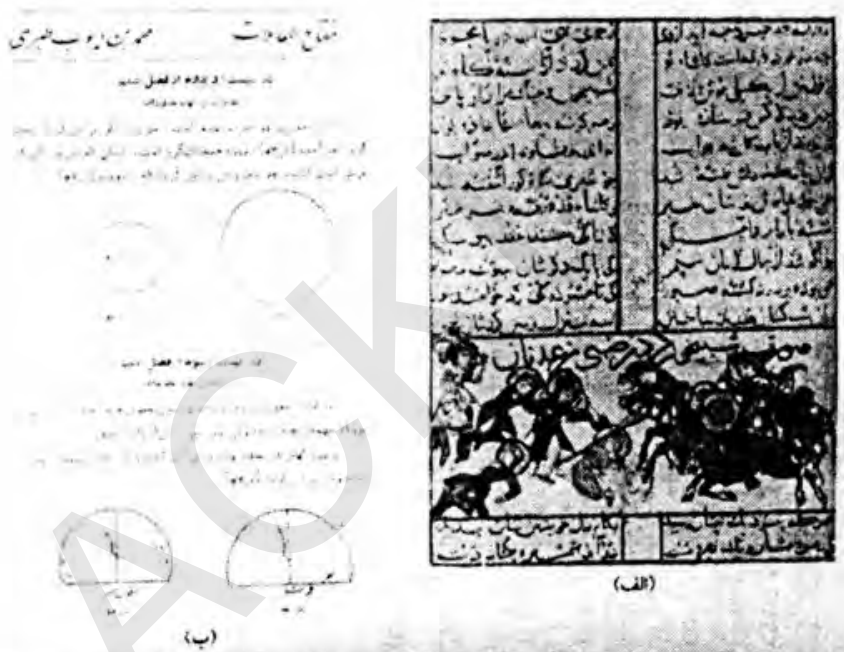

TYA

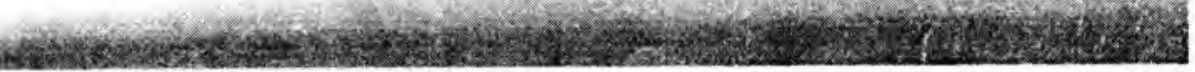




\section{امميت علم سكه شناسى از نظر باستانشناسى}

يكى از قديم نرين احتياجات انسان رفع نيازمندى در تأمين معيشت و روابطى بود كه بدان نياز مبرم محسوس ميكرديد. اين نياز همانا بدست آوردن امتعه مادى بود، كه در طول حمات و زندكى خويش جه جـ دستيابى به آن در تلاش بودند. انسانهاى ماقبل التاريخ بعد از كذشت سالِان متمادى براى بلست آوردن امتعله و تامين معيشت به صورت تدريجى به اكتشافات دهنى آماده شدند و در يى بلست آوردن نياز هاي اوليه به انديشه ور شيوه هاى انتخاب و نوع اشيا

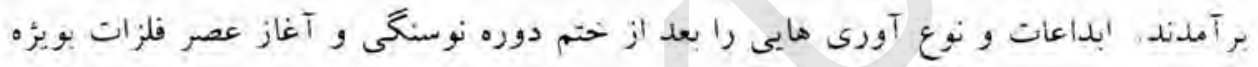
دوره مس و معرع آموختند و 2ر كثف طلا و نقره ذوب و قالب كيرى آنها در بوجود آوردن

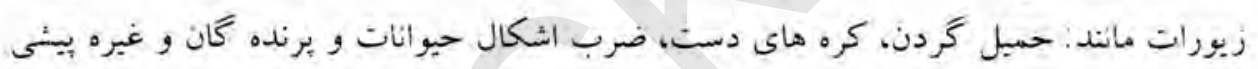

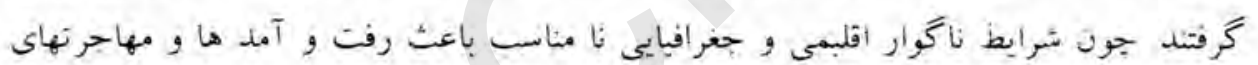

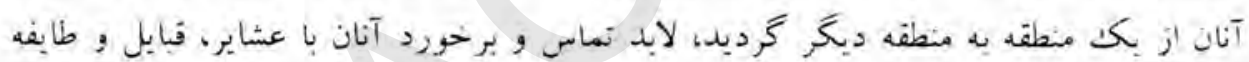
هاى منعدد، صروروت اتخاذ نيازمندى و رفع حواسته هاى آنان لا اولين تبادله و معادز ساختي أُّا يكك با ديكًر ميسر شند بعنى رفع نيازمندى و تامين معيشت انسانى از طريق تبادله اشيا حود نوعى ارز عرف و, عادات فرار كرفت و براي نخسنين بار زمبنه اخذ برحورد شى و جنس بصورت غير ارادى درميان انسانها معمول كرديد. إين توع برخورد بر تهادله اتُّا مورد نياز

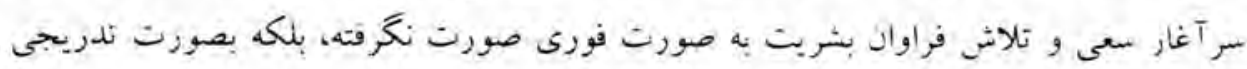

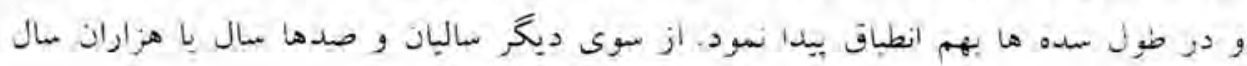


كذتت تا انسانها نه تنها به ارزش اشيا مادى بى بردند، بلكه در زمبنه تبادله اشيا مادى بحيث يك جريان بذيرفته شده و فرهنگ معيشت انسانى مبدل كرديد.(1)

در حوالى .... قبل از ميلاد در دوره برونز (مفرغ) انسانهاى فبل از تاريخ بخونه بعد از تبادله جنس به جنس در صورت تناقض و تفاوت ابعاد مادى آن موفق به نوع ارزش ثانت شدند، كه ابعاد مادى و حجم اشيا را در برابر ارزش آن ترجيع بدهند بدين اساس تبادله اشيا به صورت تصادفى و نخست از فلز آغاز نشد، بلكه با نوعيت اجناس و اشياى غير فلزى ادامه داشت هركاه يك زيور نقره يى يا طلايى را مى خواستند تبادله نمايند، مى بايست ارزش آنرا از لحاظ نوعيت كاربرد هنرى و زمان وقف شده بالاى آن با وزنى كه داشت، در نظر ميكرفتئد. بعد از مرحله تبادله اشباى همجنس در اواسط دوره برونز و آغاز دوره آهن مورد

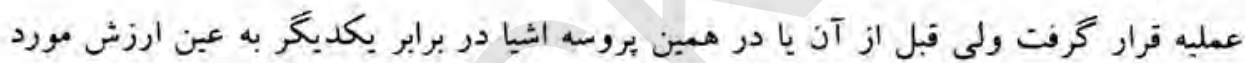

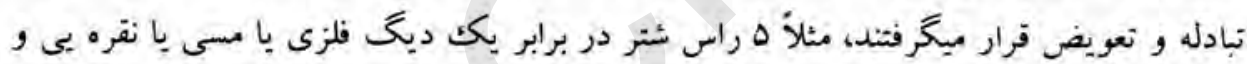

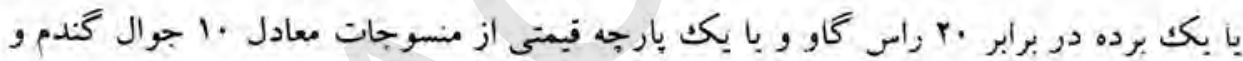
به همين منوان شتى از نظر ارزش با شى ديكر موازنه و تبادله مبكرديد، حتى در دوران باستان

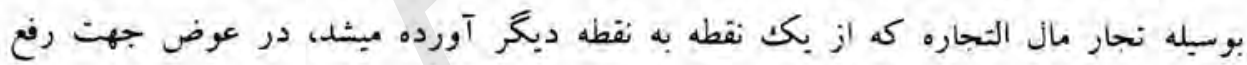

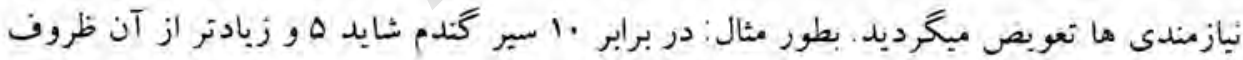
منقوش و مزٔين رومئ و يا كدام شى ديخر تبادله ميكرديد در هر حالت ائز شيوه براى انسانها مشكلات و سختى هايى رأبوجود آورده بود 
در جريان تشكيل طبقات و حاكبيت هاى مستقل و تقسيم كار در جوامع بشري و انكثافات ذهنى، فكرى و توليدى بشر توأم با تامين روابط اين معضله بر وفق موازنه اشياى فلزى و, بأ غير فلزى تامين گرديد، كه ميتوان در زمينه از مثال هاى مختصر ذيل استفاده كرد. در حجارى هاى قديم صحنه هاى وجود دارد و حكايضكر آنست، كه داد و ستد بوسبله معاوضه صورت ميكرفت جنانجه دهقان، شكارجى، جويان و مالدار در مقابل سامان آلات زينتى و ظروف ساخته شده مشغول تعويض ديده ميشوند. به همين منوال در مناطق ساحلى

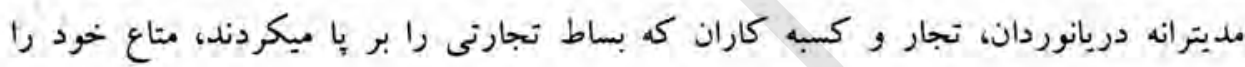
عرضه ميداشتيند و اجناس متّوع را به تعويض برده ما و اشياى قيمتى مبادله ميكردند. مثلأ

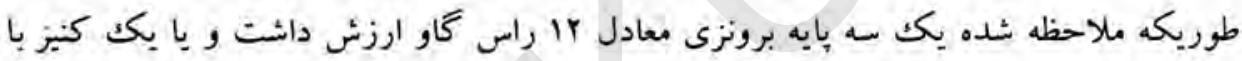
r Fاو تبادله و معاوضه ميكرديد، حتى جريمه هاى افراد و انسانها به تعويض جهاريابان وابسته بود و قرانين جريمه ها در قوائين ملل قديم و مذاهب ديده شده است. (r:r)

در اوستا در مورد مزد كارگران با گُرفن جريمه ذكرى بعمل آمده است. طوريكة در فصل هفتم ونديداد در بسيارى از قسمت هاى آن از حق الرنجه طبيب ياد شده كه براى كسانيكه از شهر محافظت مينمودند يكك اسب و براى شاهان يكك كادى جهار اسبه و براى زنان بكك ماده الاغ با بكك ماده گاو و يا يكك ماده شتر را ميرداختند. به همين منوال در عصر

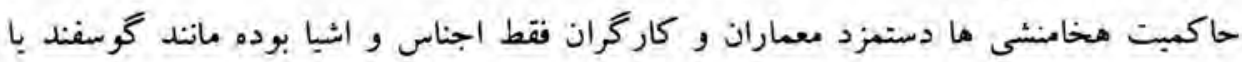
كوزه شراب كه ميتوان اين مطلب را در الواح گلى كه از تخت جمشيد بدست آمده، ارائه نمود در بعضى اوقات از انواع صدف، مهره هاى دريايى، عقيق در خاور، افريقا در جزاير 


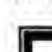

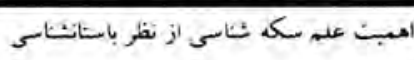

اوقيانوسيه و كثور ها و مناطق آسيايى به هدف تبادله و تجارت بكار گرفته ميثد، جنانجه كه مبلغين، سياحان و تجاران مفدارى از آنها را جهت رفع احتياجات و تامين سعيشت باخود به

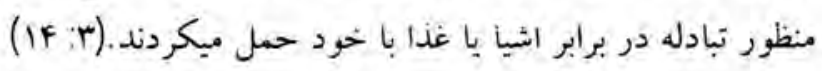

بهرصورت، صورت بندى تبادله اشيا به اشيا با در نظرداشت شرابط و تكامل حوامع تغير

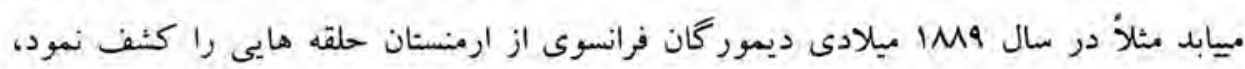

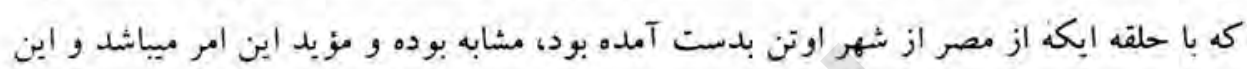
حلقه ها با ميله هاى مسى كه در كاوشهاي موهنجودارو ديده شده و به ب.... قبل آز ميلاد

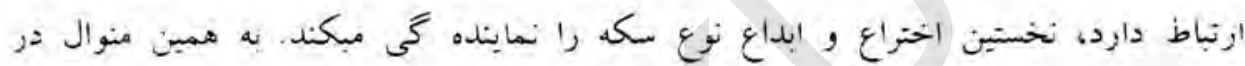

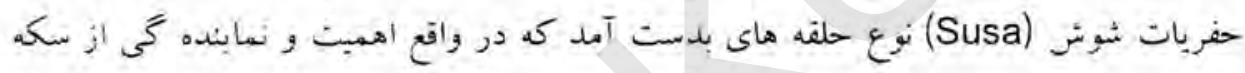
را مبهمايد براساس تحفيقات كه صورت كرفته كاربرد سكه فلزى در آثاز و مداركت باستانى

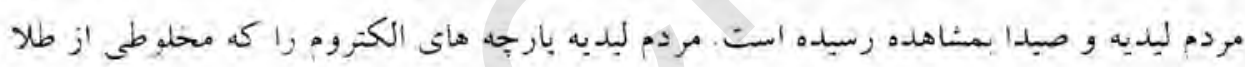
و نقره مى بود نوليد و مورد استفاده قرار ميدادند. يلوكوس مورخ و ثاريخ نويس اميراتورى مري كرمود مبخويد، همكن است شاه ارگوس كه فيدون نام داشت، نحستين كسى باشد كه سكه

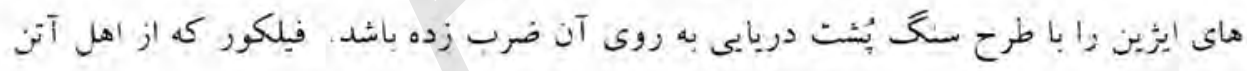
بود در قرن سوم في م عقيده داشت كم مخترع سكه يكى از قهرمانان افسانوى آنزمان بوده

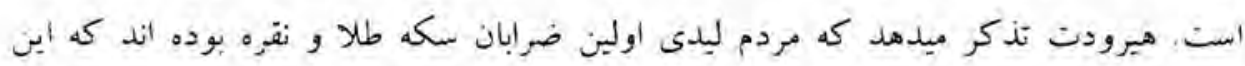

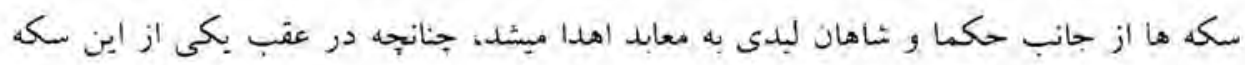


ها نقش حيوان روباه بوده و اين حيوان ثزد آنها مظهر رفتار و كردار يكى از ارباب الانواع مورد برستش آنها بود.

در بعضى شهر هاى ليديه ورسكه هاى مربوط به آن نقش حيوانات ماند شير، گاو، گرزن خوكث دريايى و غيره مشاهده شده زيرا اين حيوانات خود علامث معين شهر يا مظهر ابكه تبلور دهنده خدايان است بشمار ميرود. در سال .qV ق. م در جزيره ائزين سكه هاى نقره بيى به ضرب رسبد كه نقش سنخ بشت رادارا بود بناً سكه كه داراى وزن بود در اين دوره مدار

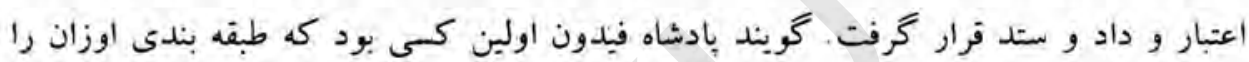
ايجاد نمود كه بنام اوزان ائزى معروف است. أرسطو فيلسوف مشهور فرن جهارم ق. م مرن مينويسد كه در معبد هير' Hera در روى ديوارها سكه هاى مختلف الشكل فلزى نصب شده است، كه فيدون يَادشاه ارگون Argon آنرا وقف معبد نموده است. جنانجه بعد از كاوش هاى

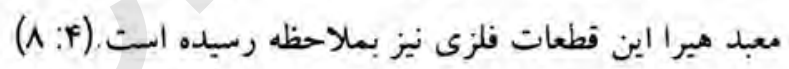

بعدها در عصر كيزوس Kexus سكه هاى بسيار مهم و معروف بضرب رسبد كه ميتوان آترا اولي سكه هاى حقيقى دانست، زيرا هم داراى روش هنرى صمرابى بوده و نير با شرابط

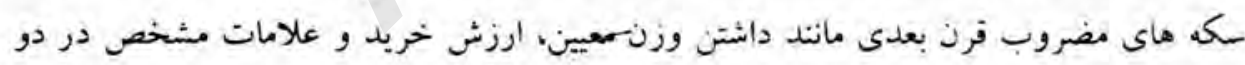
روى سكه را داشته و مورد بذيرش در عين مبادله اشبا با سكه قرار ميكرفت. در سكه هاى

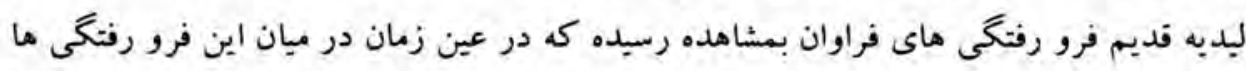
نقش حبوان بحونه روباه ملاحظه ميثود. در لبدبه روباه خود مظهر رفتار تيكو و كردار ارباب الانواع بوده و مورد احتراه و اطاعت قرار ميخرفت. روباه نماينده گیى از بكوس رب النوع 
شراب و مستى مينمايد بناً از سكه هاى ائين و لبديه مربوط بحيره مديترانه و اففس قديم يا تركيه كه ليديه هم از مربوطات مهم آن بشمار ميرفت. تا جائبكه تحفيقات علمى صورت

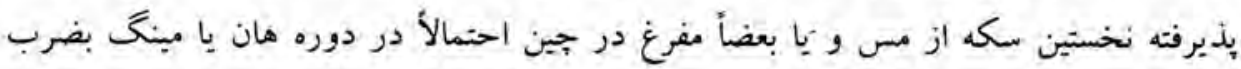
رسيده باشد. اين سكه ها در اوزان معيارى وجود داشته با بيشتر علامات و نشانه ها مورد اعتبار

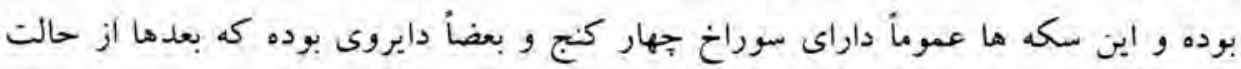
دايروى بمرور به انقسام انحنائى محبط دايره مبدل گثثته و اين تغيير در شكل و فورم سكه وابسته به نوع ذعامت در أميراتورِى جين باستان بوده است

لدين أسأس در ابرّين اولين سكه بنام كريسيد Creside بوجود آمد ولى دانتمندان به ابي

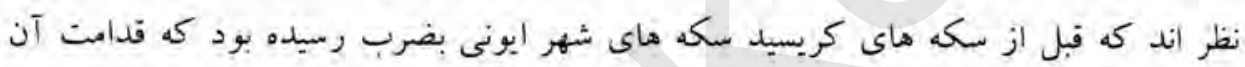
بيئتر است. در سكه هاى ليديه و افيس علاوه از روباه نقش بسيار حيوانات ديخر مانند شير گاو، خوك، گوزن و كبوتر هم كه مظهر رب النوع هاى منعددى بوده اند، ديده شده است در هند قديم سكه.هاى كهن بصورت فطعات فلزى بوده بشكل غير منظم و بعضاً مستطيل شكل كه در محتويات اين قطعات فلرى عمدتأ شكل حيو ان، درخت، كيهان يا ستاره و مهتات كه بدون علامت بوده و ارتباط به فرن شش و جهار ف. ميخير ه. بذون شكت وقتيكه مبادلات تجارتى از مراحل بدوى آن بكونه انكثاف بافته تحول يافت در واقعيت عامل اساسى آن نبادله

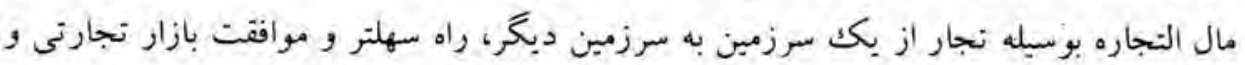
ذعامتها ميباشد همان طوريكه فورم (شكل) معادلت جنس با سكه در تبادله صورت ميكرفت بعدأ علاوه از مشخصات در روى سكه ها و قطعات فلزى كه مورد شناخت و قابل قبول فرار 
ميكرفت وزذ آن به معيار هاى معينى در ميان نجاران نيز جذيرفته شد بناً براى نوزين و كار بردن وزن ها شدند كه اين هم براي داد و ستد مشكل بود مثلأ در محتواي يوثشي سكه كه بشكل زنغ بود و در حفارى سال (19Tr و 19rF ميلادى) در شوش بوسيله دأشمندى بنام دمكنوم بدست آهد و منعلق به . .0r ق.م ميباشد، از نوع گل بخته سفيد گونه بود و به نظر دانشمندى بنام 》 كولبنل بلوى ه در مقايسه با وزن هاى شبيه به بين الهرين اين هر دو خود معيار وزن يا اوزان فبل از انكشاف سكه بوده ميتواند. وزن هاى مريوط فوف داراى بـ.ب كرام و ديخرى ع.أ كرت كه وزن مصرى است باهم مطابقت دارند. وزن هاى مانند شكل حشره كه نبز از شوش بدست آمده عين وزن و شكل از حفارى موهنجودارو و سند نيز كشف كرديده.

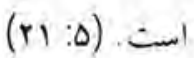

دانشهندان را عقيده براينست كه اوزان كه در هئل وجود داشت اساسأ از طريق عبلام به

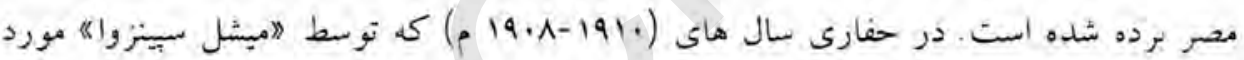

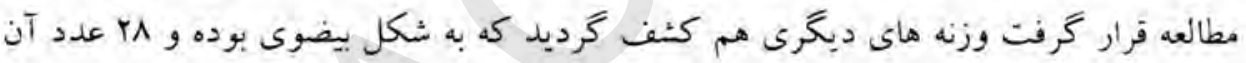
داراى علامات يا نوشته ها است كه مقدار وزن را معلوم مينمايد. اين اوزان از سنخ مرمر

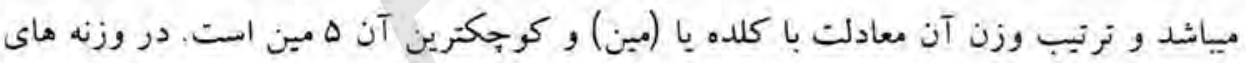

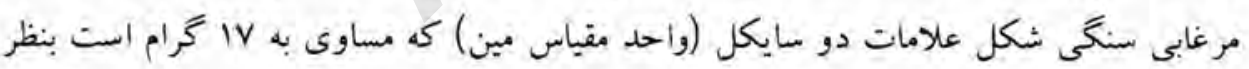

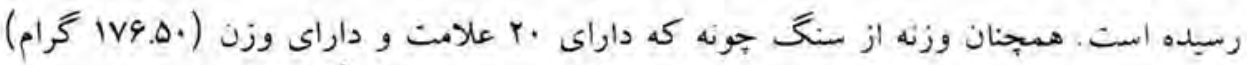

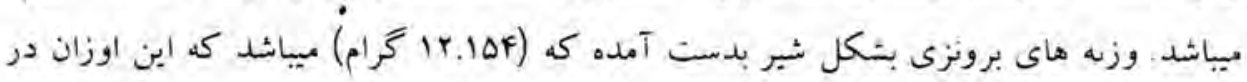

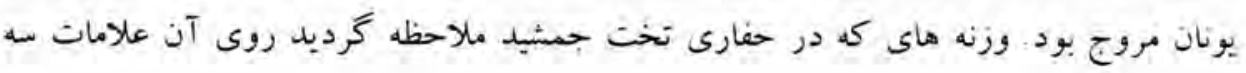


زبان يعنى (عيلامى، بابلى و فارسى) كه كلأ به خط مبخى ميباشد، بالاى اين وزنه ها بشكل

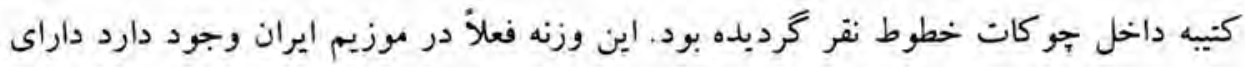
وزن . rا كارشا است. (كارشا واحد مقياس در وزن ايرانى ها ميباشد.)

دمكنوم در سال 1941 م كه در قبور عيلام و شوش به كاوشهاى نحفيقاتى خويش ادامه ميداد، علاوه از آنكه وزنه هاى سنكى مختلف الوزن و مختلف الثكل را دريافت، دو لبه ترازو

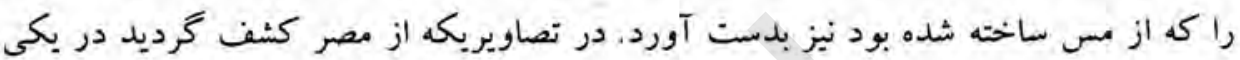
از اين تصاوير وزنه ها و نرازو يكجا بوده يعنى شى و وزنه نيز وجود داشته و حالت وزن كردن التهائ

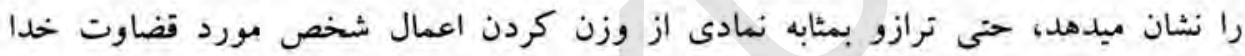

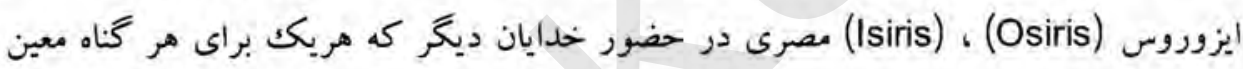
قضاوت ميكند بملاحظه ميرسد. در يكى از لوحه هاى مسى ديخريكه از مصر بدست آمده.

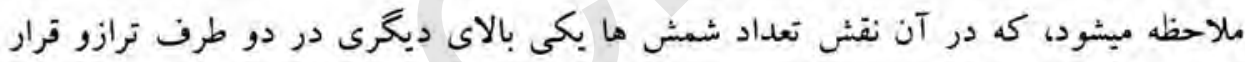

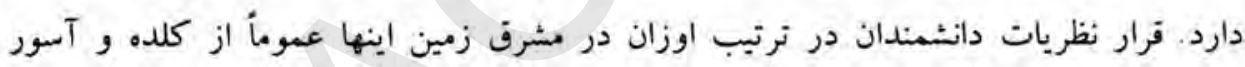

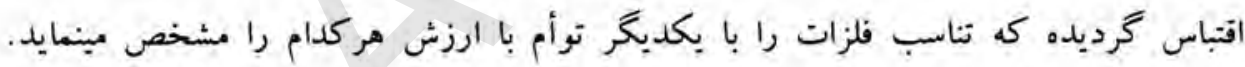

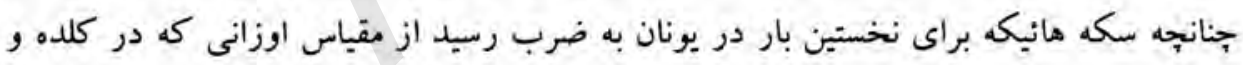

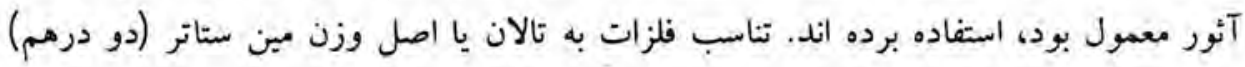

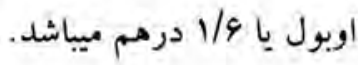

سكه هائيكه ارزش تبادله را در برابر اشيا دارد، در واقعيت امر وسيله تعويض دو جنس است

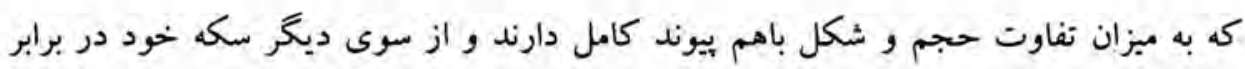




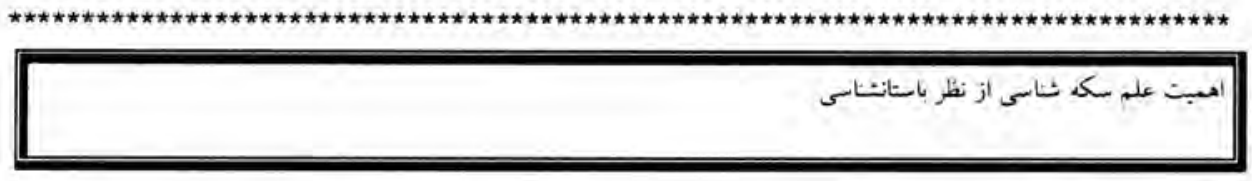

متاع يرداخته ميشود و از جانبى هم سكه جون در بين مرزها، كثورها و مناطق در دوران قرار

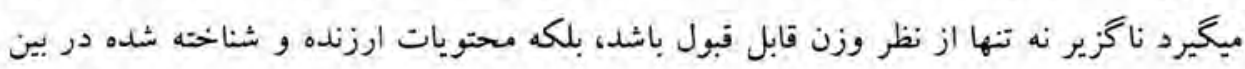

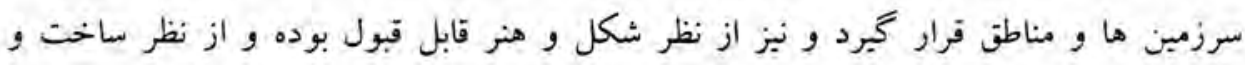

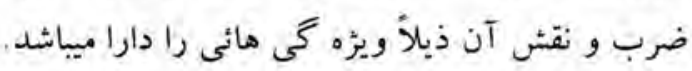
1- سكه داراي وزن متحد و معين ميياشد. r- بكه داراى حجم و اشكال ميباشد.

r- ب-ر عقب و روى سكه علامات و بعضى سمبول هاى رسمى، دولنى و منطقوى نقش ميكردد.

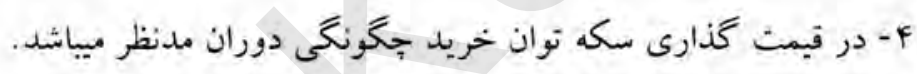
ه- سكه از نظر هنرى زيبا و به اندازه هاى نامعين ميباشد. 4- سكه از مواد متوع مانده مفرغ، مس، نقره و طلا ضرب زده ميشود. v- در سكه ها ارباب الانواع، تعميرات، تاريخ و با سنه وجود ميداشته باشد.

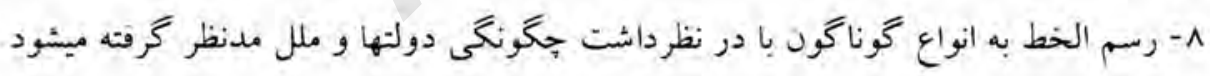
9- در سكه ها نام و القاب شاهان كه به نامش سكه ضرب ميشود، وجود دارد . 1- سكه ها با در نظرداشت كيفيت و مواد به أسم هاى مختلف باد مبشود ماندا اميانى، درهم دينار، مونس، شاهى، تنخه، اشرفى، درانه و غيره. باستشناسى افغانستان 
1 - سكه ها بعضاً داراى لعاب بوده و اين سكه ها مبدل به مدالها ميشود

rا - در سكه هاى قديم علامات فارقه ميان شهر، قريه، رب النوع، قهرمانان و كسيكه سكه بنامش بضرب ميرسد، فرق بيدا مينمايد.

سكه وقتى عموميت را بخود اتخاذ نمود كه در تعويض اشيا نقش مهم را ايفا نمود كه اين وسميله تعويض در جوكات حجم و وسعت كوجك فلزى با معيارهاى معين بوجود آمد. در ابتدا ضر ابان در ضرابخانه ها براى كسب سكه ها نخست فلز را در كوره هاى مخصوص ذوب مبئمودند و بعدأ به طور فلز قطع شده به شكل مستطيل و يا مربع آماده مينمودند بعداً قطعات رمانبكه به صورت نسبى سرد ميشد براى ضرب مسكو كات آماده ميخرديد وزن اين قطعات از لحاظ ضخامت، طول و عرض مساوى بوده بعد از آن سكه هارا بوسيله دستكاه مخصوص كه تو سط يككن و ئناً دو نفر ضراب انجام مى بذيرفت سازمان داده ميشد. سكه ها معمولاً مدور بوده و ياً كاهى بِكونه جهاركذنج يا بيضوى ساخته ميشد: در آتن و شهر هاى يونان مخصوصاً در اسهارت و مقدونيه براى بو جود آوردن مسكر كات طريقه ديكرى را بكار بردند و آنهم سكه ها بوسيله قالب كيرى بعد از ذوبن فلز بود. قالب دو سطح حاشت كه با مواد خاص احتمالاً مواد براده شده كاربونيك و خاكستر در آن تعبيه ميشد و بعداً به خانه ها و مقطعات تفسيم بندى ميكرديد و مواد مذاب در داخل آن ريختانده ميشد بعد از سرد شدن سر جعبه هارا باز نموده و سكه ها كه درين حالت هم وزن و همكون بوده در قالب ضرابى كه از فلز سخت آماده شده بود به شيوه خاص مورد ضرب قرار ميكرفت در سكه ها معمولأ نقش وقتى بصورت واضح معلوم ميشود كه ضراب بوسيله جكث بالاى سكه قابل ضرب را (سرسكه) قوياً وارد مينمود. 


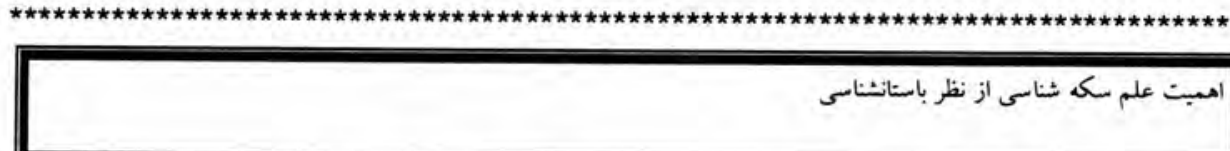

درين زمان احتمالاً به عين وسط سكه فشار با قوه ايكه وارد ميشد. بعضاً لغزش هاى ايجاد

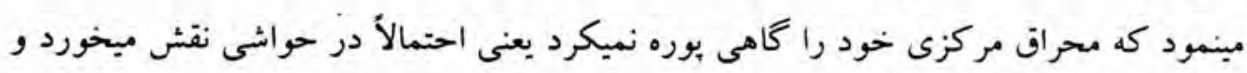

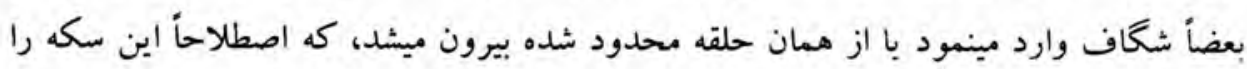

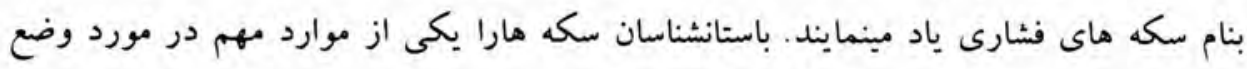

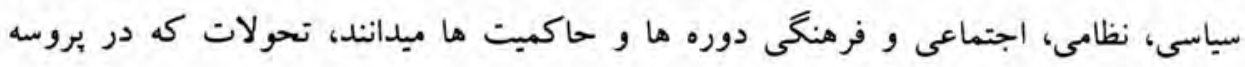

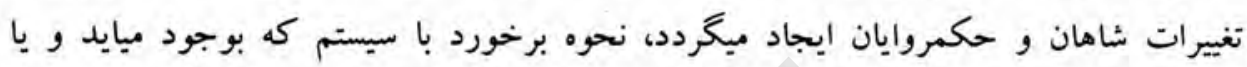

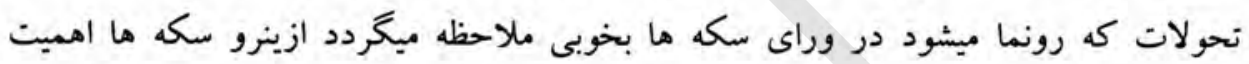

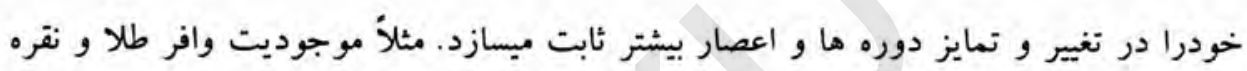

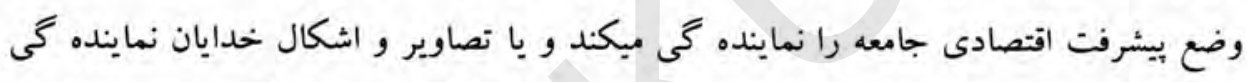

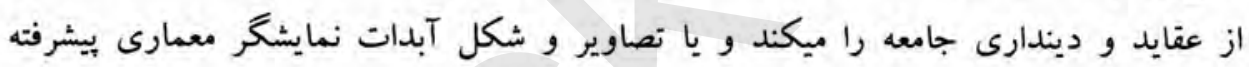

سكه شناسى بخشى مهمى از علم باستانشناسى ميباشد كه از اهميت ويزٔه اى برخوردار

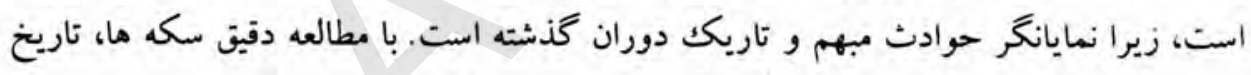

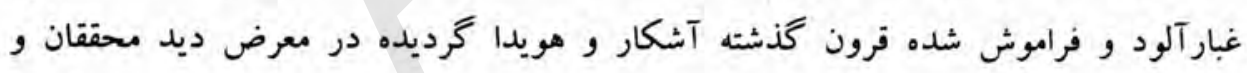

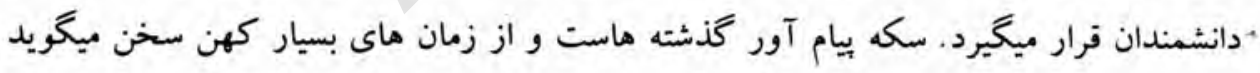

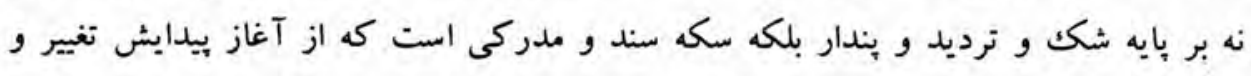

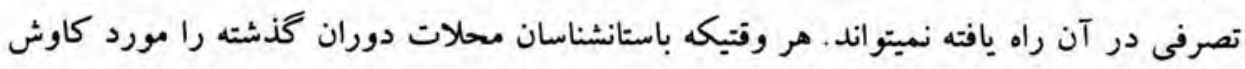

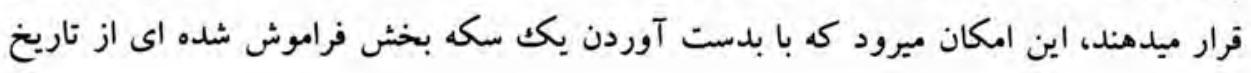


يا حلقه گظسته يكك سلسله يا حكومتى تكميل گردد، يا افسانه اى به حقيقت مبدل گرديده با نظريه اي كه مورد قبول در طول تاريخ بوده، باطل گردد. (4: ه)

سكه شناسى مانند ساير علوم معاونه باستان شناسى منحصر به شناسايى رشته مشخص

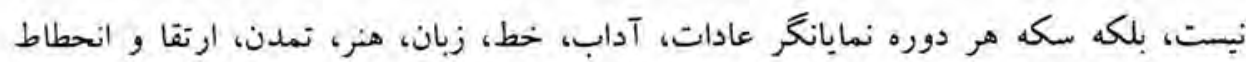
اوضاع اجتماعى، ارتباطات تجارتى ملت و مملكتى است و در حقبقت منبع اطلاعات دقيق از مردمان كذشته و قديم يعنى از عصرى كه سكه ايجاد گرديده تا بحال ميباشد. دانشهندان باستان شناسى با كوشش و زحمات فراوان توانسته اند آثار هنرى، ساختمانها، معابد و مقابر ويران قديم را از روى حدس و گمان با تصويرى از آنجه از بنا بجا مانده تعمير وتا حدى به

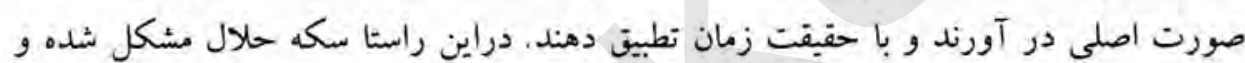
كمكت شايانى را به باستانشناسى و تاريخ هنر دنياى قديم كرده است. و بالاخره كفته ميتوانيم

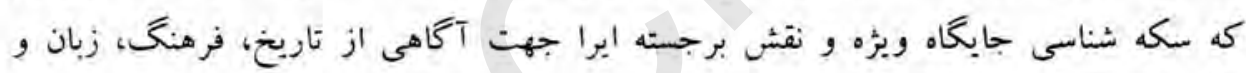
ديخر ابعاد علمى و فرهنگى مردمان دنياى قديم داشته و در اين زمينه كمكك شايانى را به علم

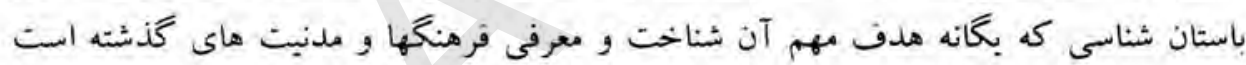
مينمايد. 
اهميت علم سكه شناسى از نظر باستانشناسى
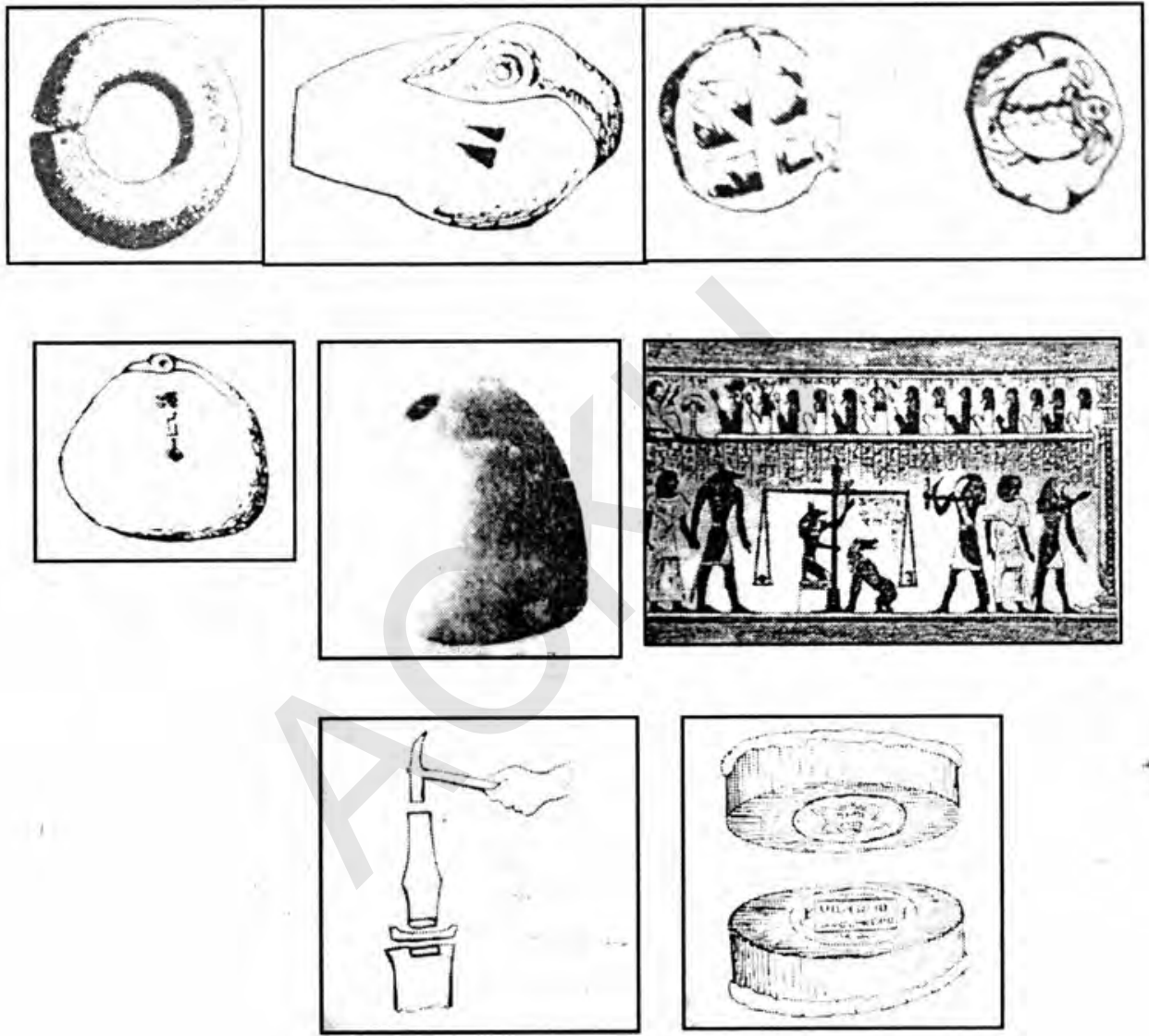
1- شارل ساماران و همكاران. روش هاى يُروهش در تاريخ، جلد دوم، مترجمان، ابوالقاسم

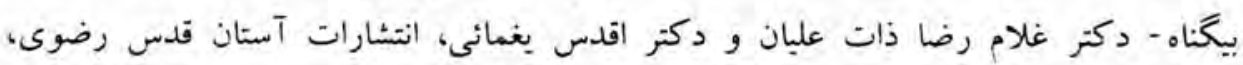

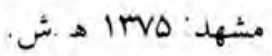

r- ملكه بيانى. تاريخ سكه، انتشارات دانشگًاه تهران، جاب هفتم، ايران: هNrاهش.

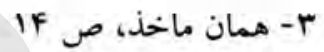

F- على اكبر سر افراز و فريدون آورزمانى، سكه هاى ايران از آغاز تا دوران زنديه، انتشارات

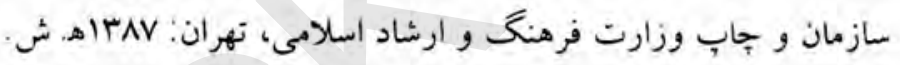

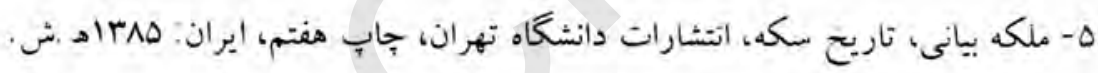
9- (9) - ومان ماخذ، ص 9. 
خباألحق خبايي

گزارش علمى از ساحه (FD. ) ششمين معبد مكشوفه در مس عينك

شواهد بى شمار و متنوع تاريخى كواه براين است كه افغانستان كهن سال با موقعيت

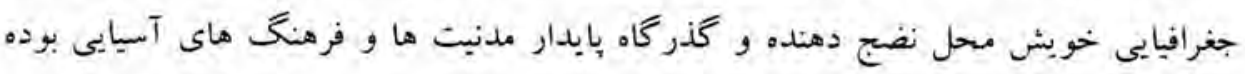

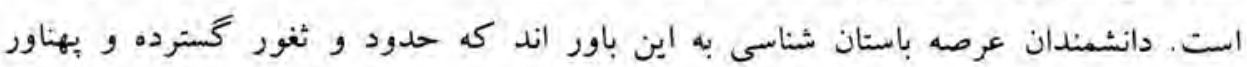

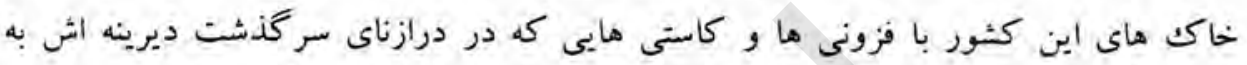

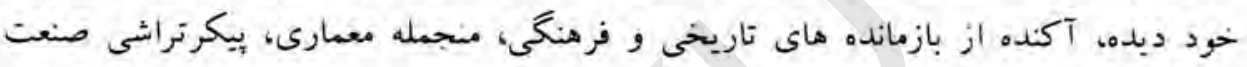

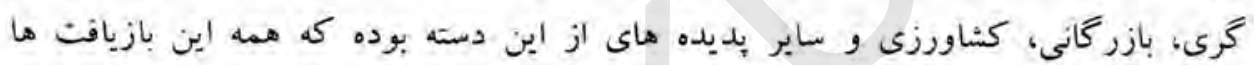
بازتابكر غنامندى بيشينه تاريخى اين خطه به شمار مى بـ آيند.

وقتى ملتى را ميتوان باشكوه و داراى ثقافت دير زمان دانست كه مماثل مادى و معنوى آن نه تهها براى خودشان بلكه براى جهانيان به تصوير و معرفى كرفته شود، اين معرفت ييرامون

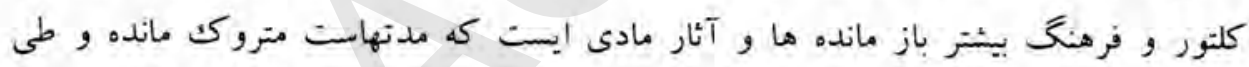
قرون و اعصار به خاكك نشسته، كه از دركك و فهم آن آكاهى در ميان توده ها و مردم وجود مرد

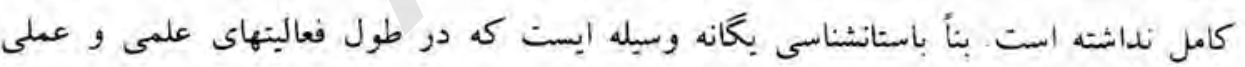
حويش نفث شايسته يى را در بازتاب رويدادها، ابداعات، و تنوعات مادى و معنوى عرصه هاى مختلف حيات انسانكه در بارينه ها و دوره هاى باستان براي تسل هاى امروزى در بهناى بهاي از عمق زمين قرار دارد، بالاثر سعى و تلاش بى بديل شان به كاوش و تحقيق گرفته ميشود و در معرفت و آكاهى تاريخ، علاوه گیى هاى فراوانى را ايفا مينمايد. 
ولايت لوزَر در جنوب يايتخت همانند صفحات شمال كابل خاكيست زر خيز زراعتى شاداب و سرسبز و بر جمعيت. اين علاقه بين سه شهر تاريخى كابل، غزنى و گرّديز كه هر سه شهر در اعصار مختلف كانون بزرگ فرهنگى، سياسى، و ادارى بوده دريك مثلث بزرگى ونى

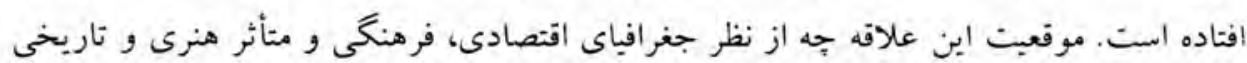
هميشه از بركات اين سه شهر برخوردار بوده كه بيان اين مطلب جايغاه و ارزش ولايت لو

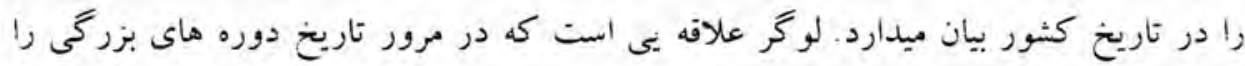

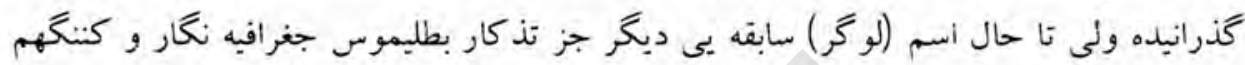

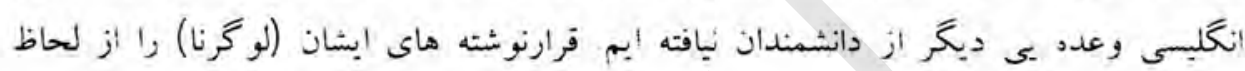
ثباهت نام و موقعيت لوكر فعلى تعبيركرده اند. جون (كر) به معنى (كوه) و (لو) مخفف (لوى) است ميتوان حدس زدكه شايد در دوره باستان اين اسم (لويغر) يعنى (كوهسار

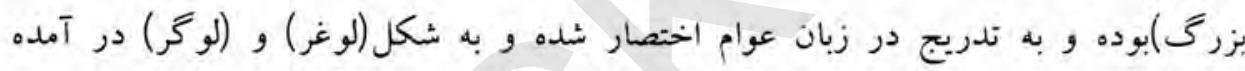

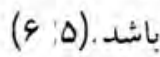
در ولايت باستانى لو گر آثار و بقاياى ازمنه كذشته بسيار زياد به ملاحظه ميرسد، هركوشه وكنار اين علاقه در روشن سازى تاريخ و فرهنگ كثور قابل ارزش و درخور تحقيق است. كشف مسكو كات از ساحه باستانى بِادخواب شانه، سجاوند، كشف مجسمه هاى اسب با بـ سواركار از گل بخته از ولسوالى موسهى، سروى وكشفيات از مناطق شاركنى، كافركوت خروار و بالآخره ساحه باستانى مس عينك كه يكى از بهترين و بر اهميت ترين ساحات تاريخى مكثوفه در افغانستان است، نه تنها بيانگر شرايط مادى زندگى مردم ما در مقاطع 


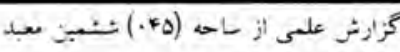

محتنف تاريخ است. بلكه تحولات فكرى و عقبذنى آنها را بيز معرفى ميدارد بوبسندة ايى كزراثى علمى صرق از ساحة باستانى مس عبنك صحبت مى نمايد، زيرا ساير ساحات از حوصله اين مفال زياد مى باشد.

ساحه باستانى مس عينك در رr كيلومترى جنوب بايتخت كشور و 1 ا كيلومترى شرق شاهراه كابل لوكر ميان كوه هاى سر به فلكك كشيده در مجاورت دومين معدن بزرك مس در جهان قرار كرفته است. ابن ساحه أبتداء در سال با791 ميلادى كشف و مورد آماركيرى فرار كرفت متعاقباً در سال raی1 در فهرست بأستانشتاسى افغانستان درج و به شكل مختصر از آن ياد كرديد انستيتوت باستانشناسى ساحه را در سال عُبا سروى تموده و از آن بازديد بعمل آوزد و به تعفيب عقد قرارداد الستخراج معدذ مس فى مابين دولت جمهورى اسلامى فغانستان و كمبنى جينايى(MCC) ، مطالعات مقدماتى را بالاى ساحه اتجام داده و به دوره هاى كوشانى الىى ورود اسلام (قرن ا-ه ميلادى) تاريخ كذارى نمودند.

بقاياى باستانى اين ساحه مساحتى حدود هزار هكتار رإ در بركرفته و نخستين حفريات اين ساحه يرعظمت توسط انستيتوت باستانشناسى تحت سريرستى كتاب خان فيضى در سال آغاز و تا كنون ادامه دارد كه نتايج خوبيرا در بر داشته است. وقتى مس عينك از نزديك مشئهده شود عظمت ساختمانهاى كوه عينك، اسكان و معابديكه در اطراف آن جون تبه كز حمبد، كافر تِه، شاه تبه،شاه مار تبه، و باقى محلات رهايشى با تِه هاى سرهم ريخته و يهناور و وسعت ائ ساحات انسانرا به حبرت مى اندازد. ساحات فوق كه از آن ياد شد طى سالهاى

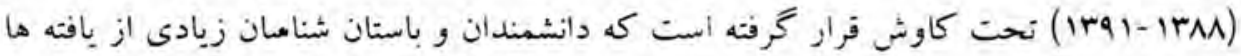


و دست آورد هاى آن طى گزارشهاى علمى، سيمينار هاى ملى و بين المللى، مبحث و مقالات، معلومات مبسوطى ارائه كرده اند. لذا با اكتفا از توضيحات سودمند إيشان و صرف نظر از تذ كار بيشتر باب سخن را روى اصل مطلب ميخشايم.

قراريكه به همه كان معلوم است دليل عمده حفريات ساحات باستانى در مسر عينك استخراج و بهره بردارى معدن مسى در اين ساحه ميباشد، فلهذا ساحاتى كه سد راه استخراج معدن بوده و يسشتر در معرض خطر قرار دارد تحت نام (ساحه سرخ) در اولويت كارى قرار

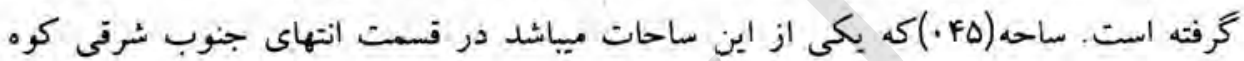
عينك به طول ه. ا متر و عرض آن در بعضى نقاط بين ·r الىى له متر ميرسد موقعيت آن شرقاً و غرباً بوده كه جناح غربى آن به كوه عينك و جناح شرفى آن به صخره هاى يوزه همين ساحه مى انجامد، قبلأ از اثر تحقيقات معدن شناسى و اجراى مطالعات مقدماتى با افراز جاه ها و جرهاى تحفيقاتى ثديلاً متضرر شده كه مسير اين جرها بعضى از ساختمان ها و ديوار ها را تخريب و حتى از بنياد ويران كرده است.(تصاوير 1-r و تربيم 1) 


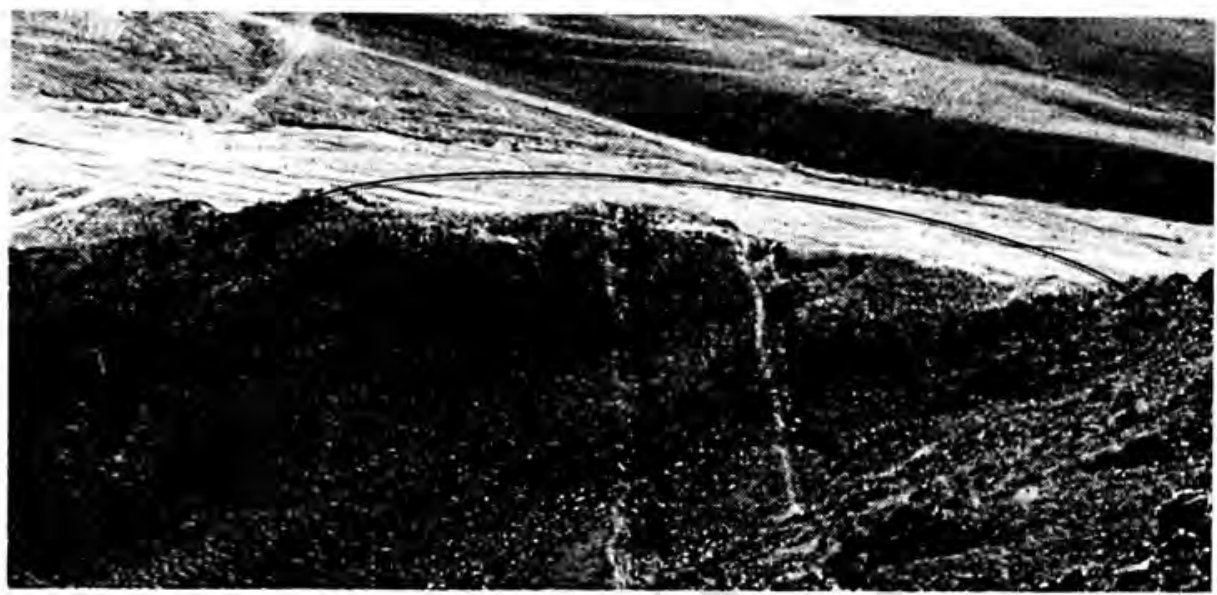

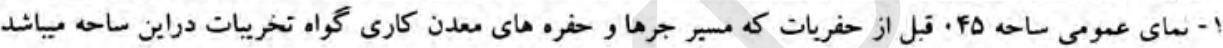

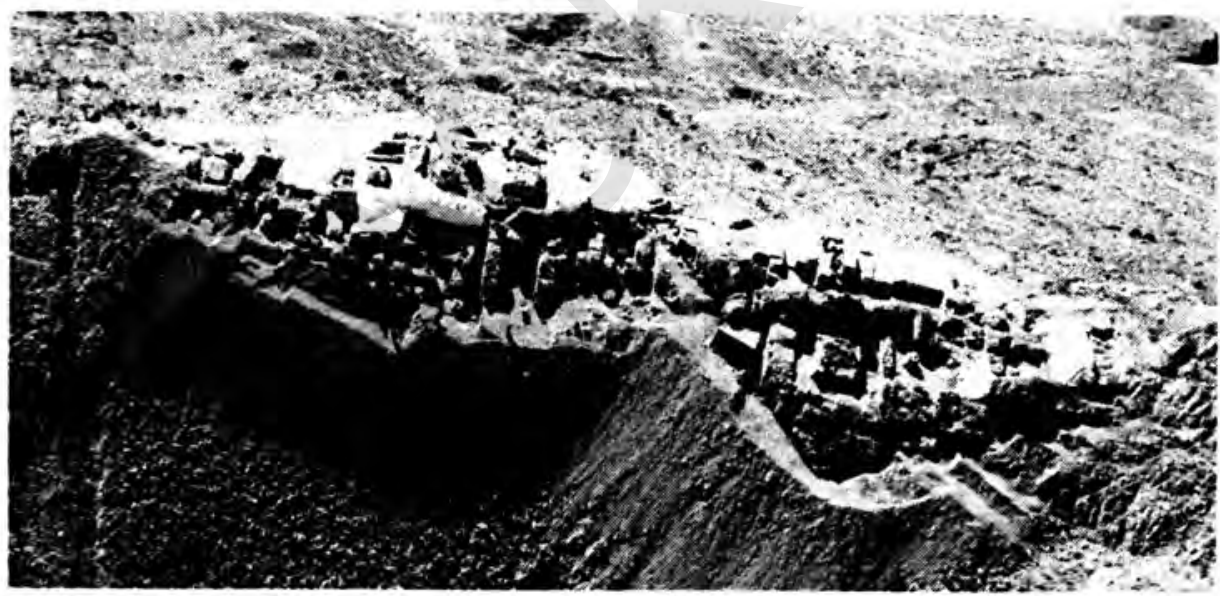

نماى عمومى ساحه از جناح شمال غربى در جريان حفريات 


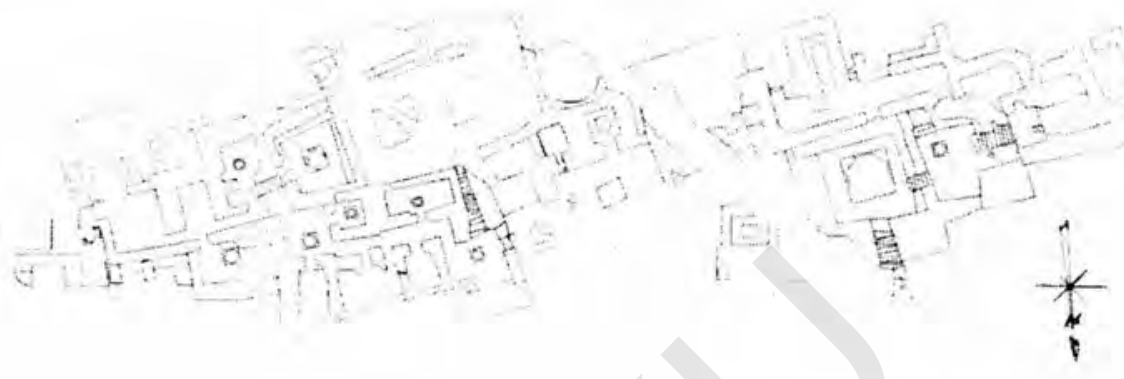

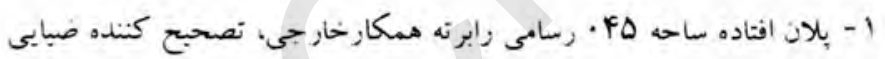

اين ساحه كه در يكك نقطه بلند و حاكم بالاى اسكان و معابد ساحات بائين، و بالاى تنگى با معبر بزرگ اين دهكده، احراز موقعيث نموده و جشم انداز خوبى بالاى اين دو جهت دارد ابثدا حدس و قياس بر اين بود كه ممكن اين ساحه بكك محل نظارتى و حفاظتى با جند اتاق

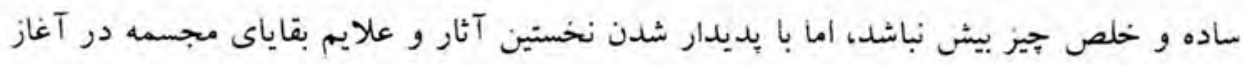

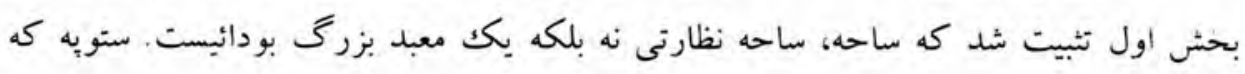

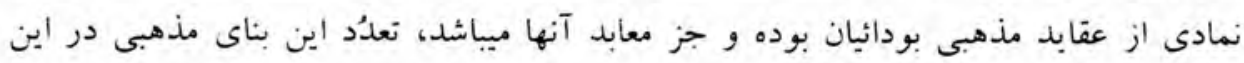

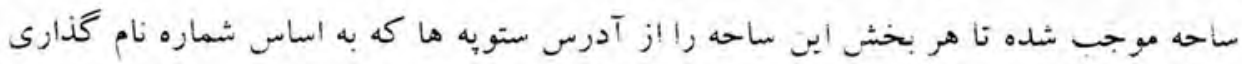


شده اند توضيح دهيم. أولين ستوبه شماره يك نذرى به اندازه (ارتفاع •1.1 عرض هـ اسانتى متر) با دو طبعه مُربع و دايروى مركب از سنخ هاى متورق با تزئينات كًل لوتوس در طبقه دايروى يا بالايى و هشت كانسول يا ستون يايه در جدار خارجى طبقه اول يا مُربع، كه در يكك صحن سنگ فرش بنا يافته از نخستين يافته هاى ما در بخش اول يا بخش غربى اين ساحه ميباشد.

بالترتبب ستويه شماره دو يا اولين ستويه مركزى مربع شكل كه در جوار شرقى ستوبه شماره يكك در سطح تقريباً ه.ا متر بِائين تر، رُخ به شمال ساحه اعمار شده، به (ارتفاع .r.r و عرض •q.r متر) داراى دو طبقه فقط از سمت جنوب طبقه اول آن سالم و طبقه دوم آن كه اصلش هشت ضلعى بوده اكنون تنها سه ضلع آن با سه رواق (خالى) به ارتفاع ه هانتى متر قسماً سالم متباقى از سه سمت ديخر كاملاً از هم ياشيده و تخريب گرديده است. صحن يا دهليز طواف اين ستويه كه همجنان سنخ فرش ميباشد در قسمت جنوب آن سكوى طويلى به اندازه (طول ·r.r ارتفاع ها.اعرض .1.1 متر)ساخته شده كه احتمالاً نظر به آثار و قراين موجوده، مجسمه خوابيده بالاى اين سكو وجود داشته كه اكنون جز انبار كِل جيزى از آن باقى نمانده است. ( تصاوير r-F 


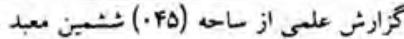
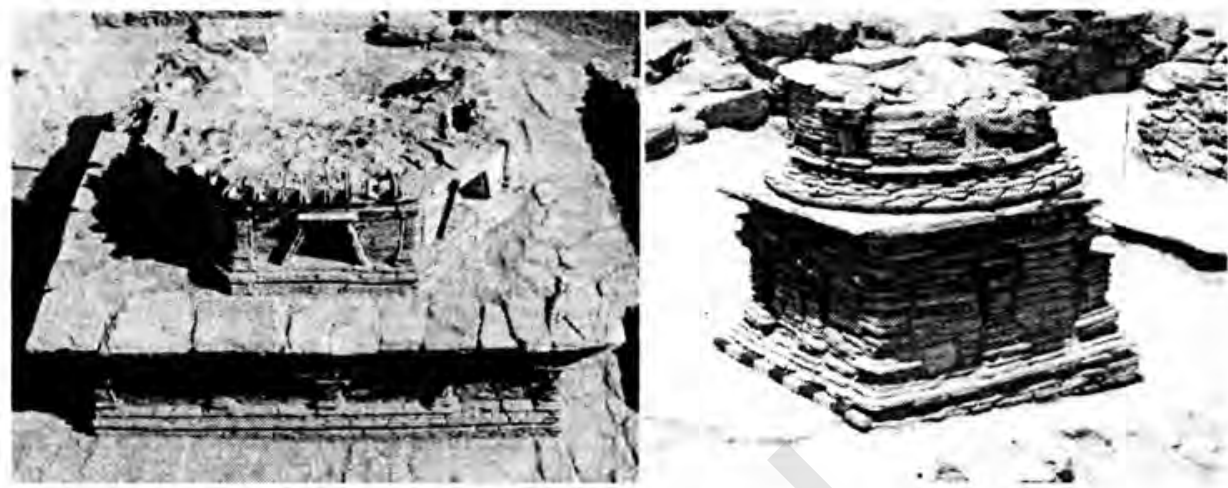
تماى جنوبى اولين ستوبه مركزى هشت صلعى در بخش اول ساحه

سنوبه نذرى شماره بكت با تزئينات كر لوتوس در بختش اول ساحه
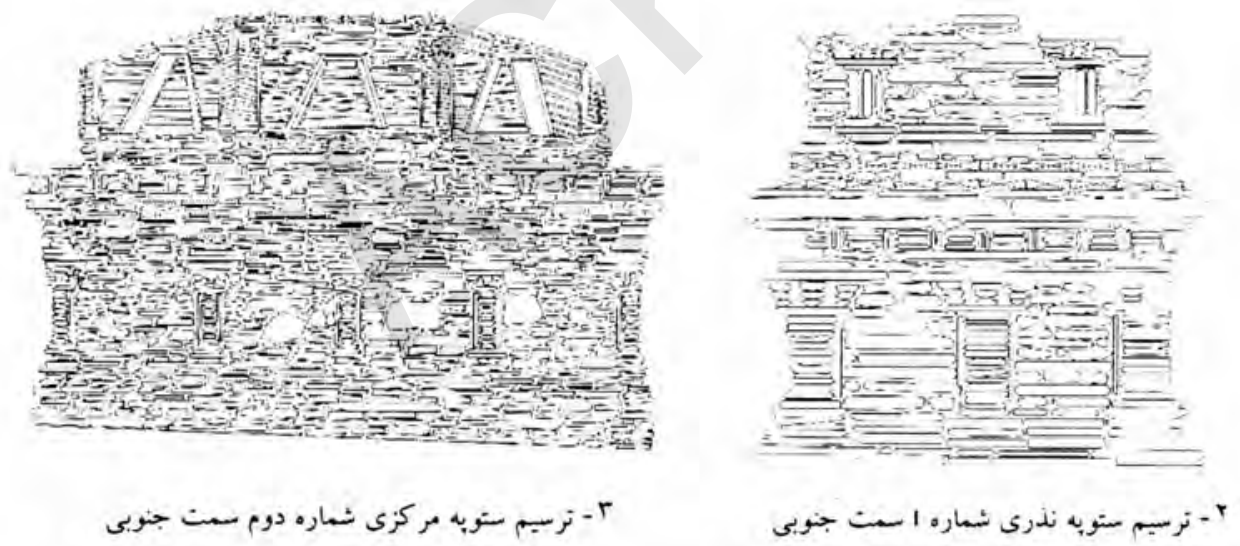

$$
\text { رسامه. ضيائه. }
$$


اين معبد جون در يك نقطه مرتفع و شبب دار بنا يافته اراضى نا هموار و سراشيبى هاى آن قسميست كه ساختمانها عموماً بشكل طبقه، طبقه يا در سطوح بائين تر از يكك ديكر طرح شده فلهذا جهارده بته زينه سنگى در جناح شمالى، اين ستوبه را با ساختمانهاى سمت شرقى مرتبط ساخته و يا هم احتمالأ همين زينه راه عمومى معبد از سمت بائين باشد. هميجنان شش بِّه زينه ديكر در سمت غرب در يكك طرح دفيق و موزون اين ستوبه را با ستويه شماره بك بالاخص با دهليز و اتاق راهبين كه در عقب يا جناح جنوبى اين ستويه وجود دارد، وصل ميبازد. اين ساحه كه ابتدا به خاطر سهل سازى كار به دو بخش شرفى و عربى درست از مسير همان جرهاى قبلأ حفر شده تقسيم گرميده، حدود جهارده ستويه خورد و بزرگ را به اشكال مختلف در خود جا داده است ساختمان ها و بناهاى آن به گرنه بخش بخش يا در اساس ساختمان از هم جدا است، درزها و خطوط منفصل بين ديوار ها واضحأ بيان ميكند كه ساخت و ساز اين بناها همزمان نبوده و يا هم احتمالاً هر بخش اين معبد كه در طرح و شيوه ساختمانى از هم متفاوت اند، از لحاظ عقايد دينى ايشان مدكن جند مذهب و طريقه در اينجا از خود عبادنكاه داشته اند. همين كونه ستويه هاى مركزى شماره r و F كه در يكك صحن يا محوطه مستطيل شكل (ه.01 × 9 متر) در سمت جنوب و آغاز بخش دوم جوار شرقى بناى مدور سنگى (احتمالأ برج) بالمقابل هم بنا يافته، كاملأ متفاوت ميباشند. ستويه شماره سوم به اندازه (طول و عرض ب در r و ارتفاع •l.V متر) مركب از سنگهاى منظم در يكك طرح زيبا داراى جهار رواف بوده كه دوى آن سالم اما خالى و دوى ديگًر آن در سمت غربى و جنوبى قبلاً از اثر كاوشهاي غير مسلكى از بين رفته و ستويه را از وسط به دو حصه تقسيم كرده و در بعضى

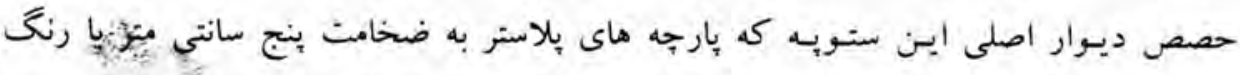




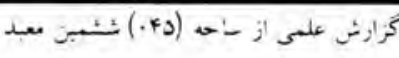

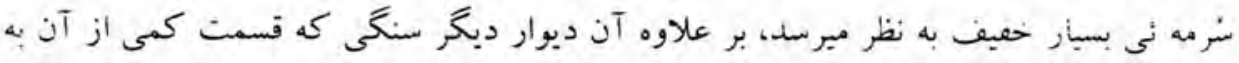
ضخأمت هr سانتى باقى مانده، ممكن بخاطر حفاظت از رنخ و بالاستر ايى بنا و بإ بخاطر نغيير نكل و دوباره سازى سنوبد اعمار شده باشد، وجود دأرد، افزون براين ستوبه شماره جهار كه ممكن قديم ترين با اولين ساختمان در اين ساحه باشد به اندازه (هاب در ه.r ارتفاع •ᄉ ا متر)

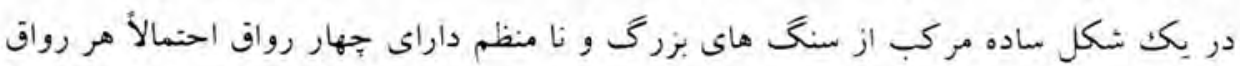
دوباره بأ سنگ ستوبه ها در اين ساحه محزا ميسازد، طرح ساختمان و موجوديت جوبهاى منظم كار شده در نَتها و قسمت هاى بيائينى اطراف اين ستويه ميباشد، كه تمامى حصص اتصال ابن جوبها با پارجه هاى فلزى هخصوص (كج گونه)محكم گردياه، كه اكنون جز از بارجه هاى يوسيده شده و بقاباى يودر كونه جوب و آهن جيزى بيش بانى نيست. قابل ذكر است كه تمامى دور و بر ائز ستويه داراى سكوها بوده و احتمالاً مجسمه هأى بالاى اين سكو ها وجود داشته، كه فقط دربافت سر يكك مجسمه كلى از قسمت شمالى و دو مجسمه ايستاده يكى فاقد سر و بدون زيخ با كمبودى هاى رينتى دز فسمت بدنه، ديكرش ايستاده زو به ديوار سكو نر فسمت شمال غربى اين ستوِه ميتواند مصداق حذس ما در ابن باره باشد، أما از اثر حوادث طبعى و كندن كاريهاى دزدانه و غير اصولى جز بقاياى جند جوره بِا از بجلك به بِائين و بِارجه هاى مخروبه ور انبار كل جيرى ديكر از مجسمه هاى منصوب در اطراف اين ستوبه باقى نمانده 


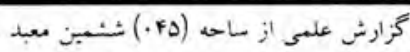

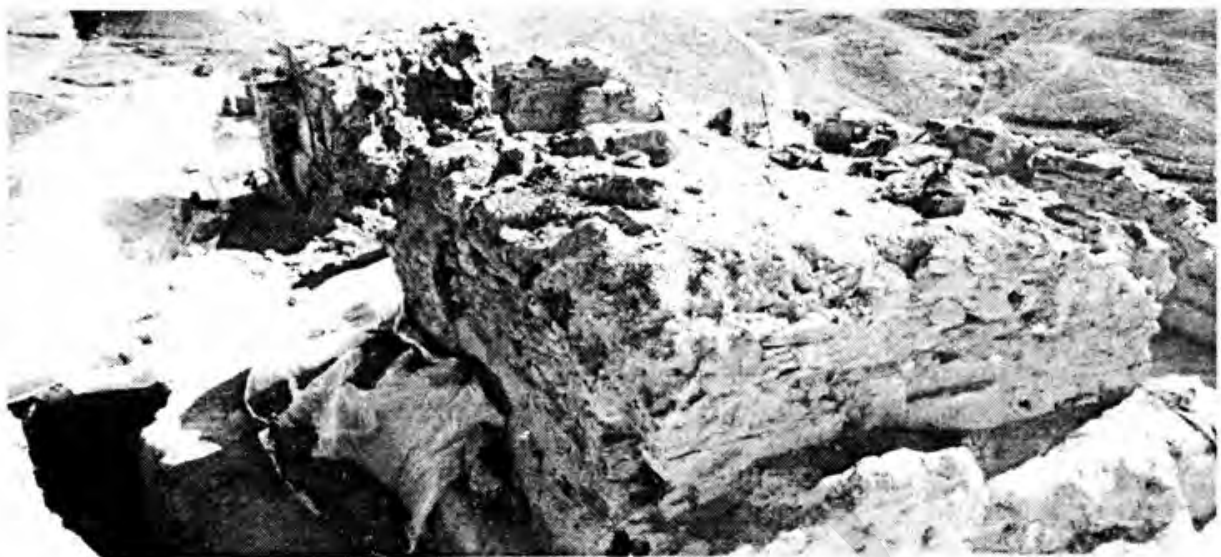

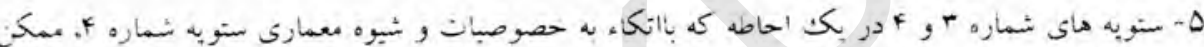

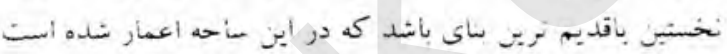
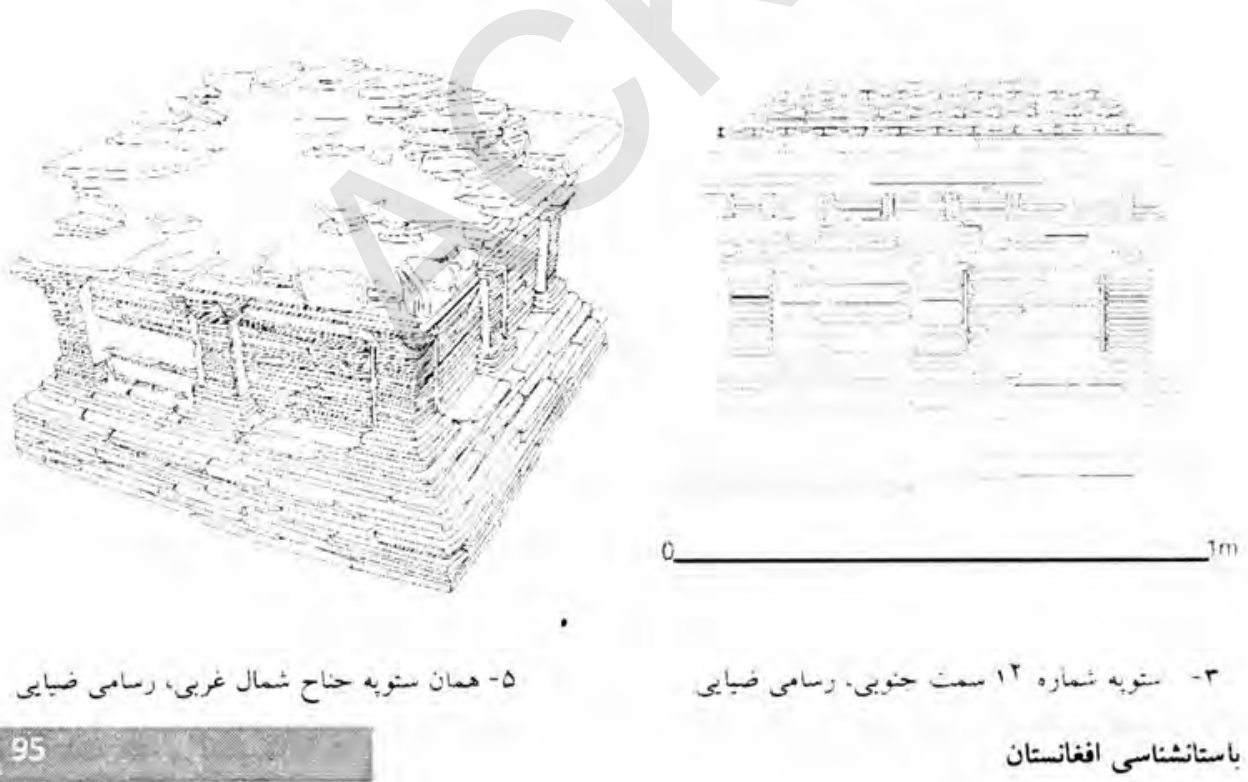


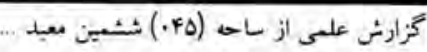

جيزى كه تا هنوز از دست آورد ماي خوب و لامثال اين ساحه محسوب شله و منتع الهام از جكونكى آداب، رسوم، آين، معتقدات و نحوه اقتصاد در خصوص اين ساحه بوده همانا

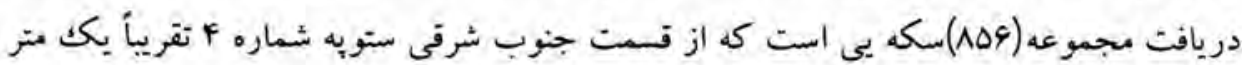
بائين تر از سطح دهليز ستويه از بين خاكهاى نرم در يكك خلاع سه كنجى كه كويا خود ساخته بوده، بلست آمده است. هر جند در مورد مسكو كات اين ساحه مطلبى در مجله تحت نام لاكاوش هاى اخير در افغانستانه جابِ موسسه دافا، ارائه گرديده مكر تهيه آن مطالب با

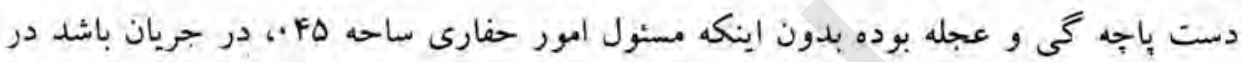
خفا صورت كر فته، ضمن اشتباهات املائى و عدم رعايت اصول نكارش مطالب آذ به كونه سطحى بوده بروهشيى كه دربر كِرئده منابع و مآخذ باشَد نيست. به هرحال اين سكه ها كه در هجموع در شكل و ساختمان يكى اند احتمالاً سكه هاى مضروب همين ساحه بوده زيرا بكانه جيزى كه مردم را در آن زمان در اين جا كشانده همي كان عظيم مس است و همجنان فرار شو اهد، ممكن دومين ضرأب خانه دوره حاكميت كوشانى ها بعد از كايسا، مس عينك باشد.

نظر به تحقيقات ابتدائى كه بالاى مسكو كات اين ساحه صورت گرفته و با در نظرداشت نشانه ها و اشكال بششت و روى سكه ها به احتمال زياد إين سكه ها كايى سكه هاى واسودوا

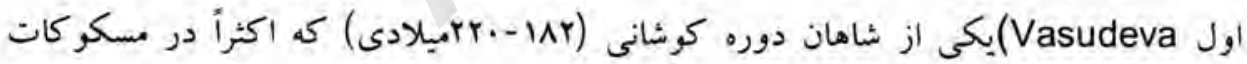

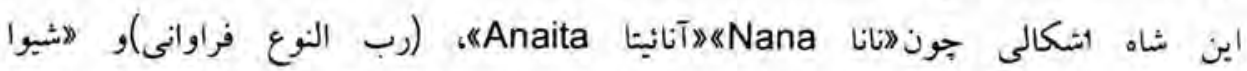
«hiva 
النوع شيوا تصوير شده است. و احتمالأ به خاطر بازسازى و ضروريات اين معبد اعانه و يا هديه شده است.(تصاوبر v-4)
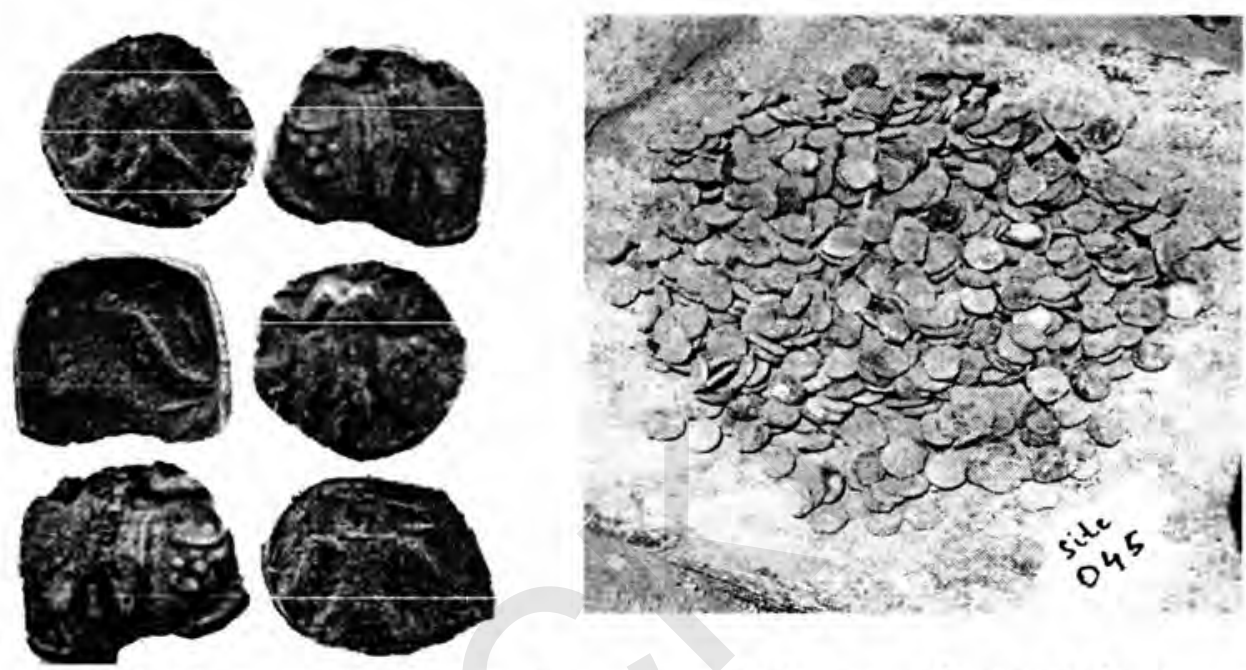

4.مجموعه مسكو كات وه内 سكه يى قبل از باكث كارى بوشبده V.تعدادى از سكه هاى مجموعه بعد از باكث كارى

$$
\text { بأ إكايد سبز }
$$

همانطوريكه ستوبه جز مهم يكك معبد ميباشد مجسمه ها هم بخش عمده يكك برستشگاه بوده و مقام شامخى را در دين بوديزم داراست. قرار ملحوظات عينى كفته ميتوانيم حدود.4 تا. V. مجسمه خورد و بزرگ

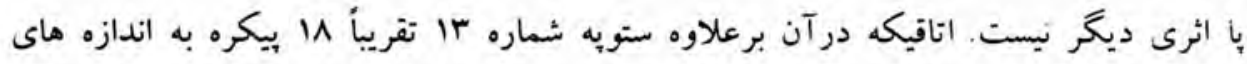
مختلف تجسم يافته، در قسمت شمالى ستوبه شماره بr به شكل مستطيل ( X ×.r.r متر) بنايافته، 
مجسمه هاي ايز اتاق كه به جز أز سمت شهمال اتاق در سه طرف ديخً جسبيده به ديوار بهلوى همديكر طرح شده، كاملاً فرسوده و بدون رنخً و فاقد سر ميباشند و احتمالاً يكى از صحنه هاى آموزشى يا اجراى مراسم خاص مذهبى را تشئل كرده اند. افزون براين، اتاق ديخرى كه جوار شرقى إين اتاق قرار دارد ضمن ستوبه شماره ^ كه در وسط آن ساخته شده سه جناح آن نه جز آز سهت شرق كه دروازه اتاق است، داراى رواق هى باشد در رواف جنوبى اين اتاق بك مجسمه نشسته بودا كه نوكث بينى آن اندكى شكسته متباقى اندام آن تقريباً سالم ميباشد، با

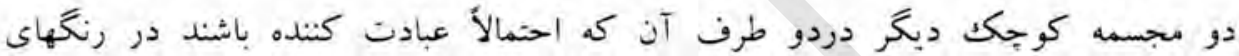

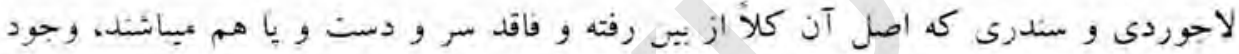

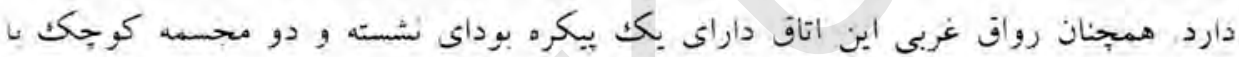
عين خصوصيات ميباشد اما آوانيكه اين ساحه به دلايل نا أمنيها، مشكلات قبيله وى ... مثروك5 شده كمان بر اين است كه همه راه ها، اتاقها، حجره ها و رواقها توسط خود فردم همان محل و

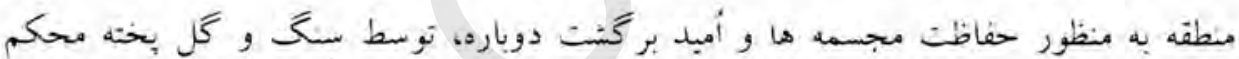
نموده اند ناء از اثٔر ائي كار رواق غربى أين اتاق شديلأ نخريب كرديده و جيرى قابل ملاحظه يى در آن باقى نمانده الست. رواق سومى ياً شمالى همجنان داراى يكك فجسمه بودا در حال نشسته بوده كه با اندكث تفاوت در شكل و هنر بكار رفته در مجسمده ها مى باشيد و وضعيت بس از دريافت آنها به دليل بسته كردن رواف با كل بخته و سنح، بسبار شديد بوده و

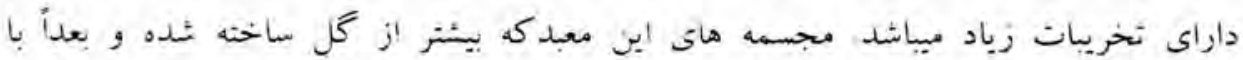

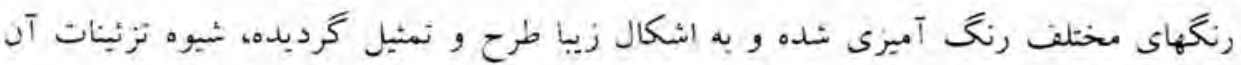

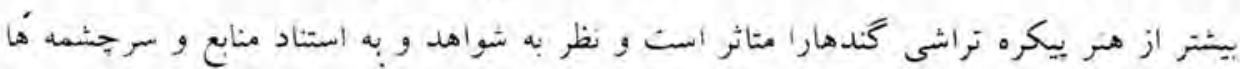


ريأدتر بيكره هاى مس عينك با آثار تِه نارنج، خواجه صفا، خروار لو گر و فندقستان شباهت دارد كه قدامت تاريخى اين آثار بين قرون F-9 ميلادى نسبت داده شده است. ( تصاوير -ه )
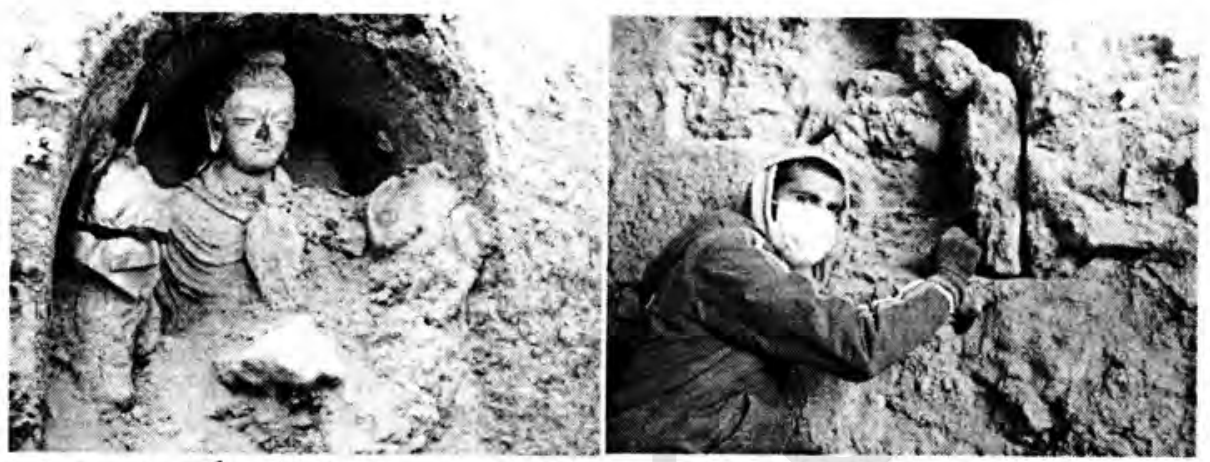

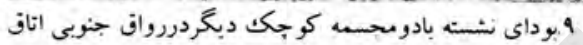

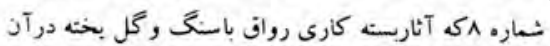

$$
\text { ديده مييود }
$$

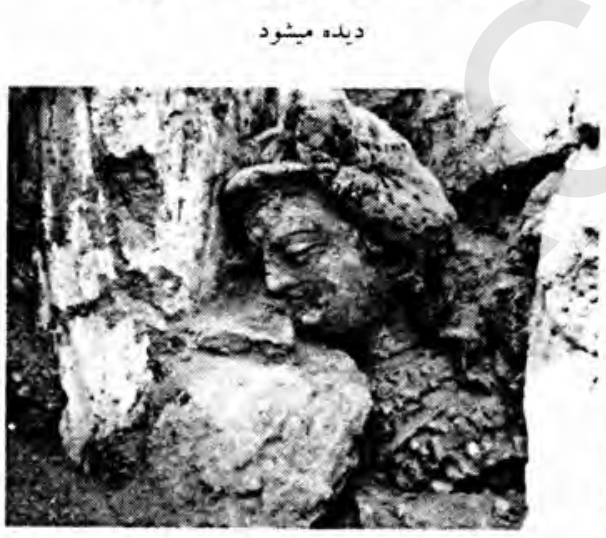

Aحربان كاروباكث كارى دررواق ئسالى اناق نسماره

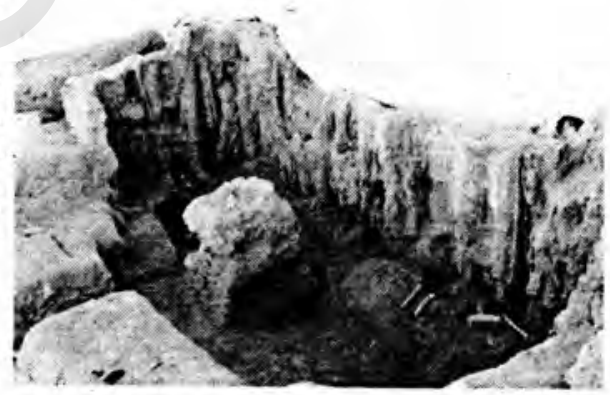

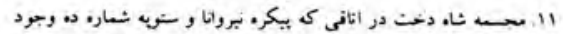

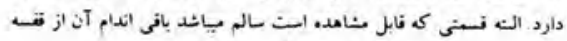

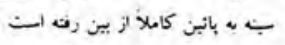

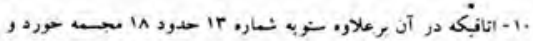

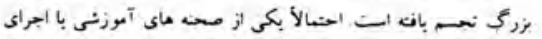

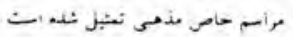


قسمبكه كفته آمديم اين معبد متشكل از جندين بخش است كه هر بخش از لحاظ شيوه معمارى و طرز ساختمانى از هم متفاوت ميباشند و هر كدام با تفاوت زمانى يعنى مرحله يى اعمار شده است. بدين ملحوظ اتاقيكه در آن يَكره خوابيده بودا و تقريباً شانزده مجسمه خورد و بزرگ ع ديخر در اطراف آن طرح و تزئين شده، در فسمت شرفى ستوبه شماره بنج اعمار

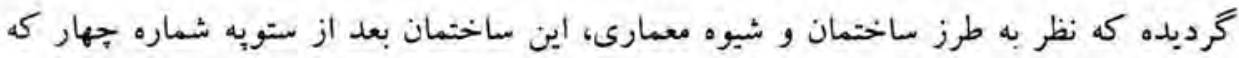
احتمالأ نخستين بنا در اين ساحه باشد، از جمع ساختمان هايست كه نسبت به ساختمانهاى بخش اول يا بخش غربى قديمى تر است، در نتيجه ساحه ه\&. كه تعلدُ ساختمانها و بناهاى مذهبى را در خود جا داده، بيانكر يكك زندگى متداوم و سابفه ترى نسبت به اقوامى كه در اين

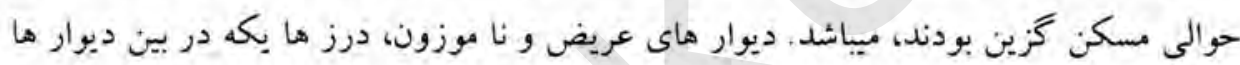
نبش هايكه گويا زمانى دروازه بوده بعدأ دوباره به دليل بازسازى يا تغيير شكل ساختمان

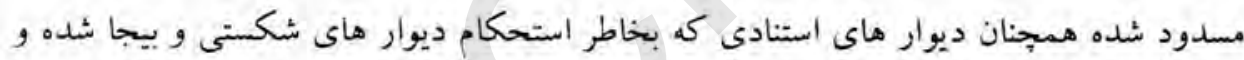
خمبده اعمار شده اند، گاهى هم ساختمانى بالاى ساختمان قبلى بنا بافته، همه نشان ميدهد كه اين ساحه از بدو تاسيس آن جندين بار ترميم و بازسازى و يا هم نوسازى شده است، كه قابل ملاحظه مى باشد.

در خاتمه ميخواهم تذكر دهم إينكه حفريات اين ساحه تحت سريرستى نويسنده مقاله هذا بوده، كار تحقيقات باستانشناسى آن به درجه اكمال نرسيده، عجالتاً هر جه در اين جا مينويسم با فيد احتياط است. مقصد مان صرف آكاهى مردم عامه و دوستداران تاريخ و فرهنگ، از يكك كشف مهم باستانى است. كثفياتى كه امروزه شهره و آوازه آن حتى بيرون از مرز هاى كشور 


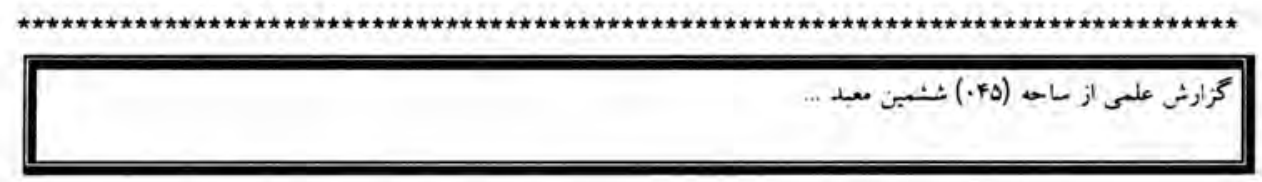

زبانه ميزند و يقينأ كه با كثف اين جنين ساحات عظيم تاريخى تشت رسوايى تاريخ نويسان

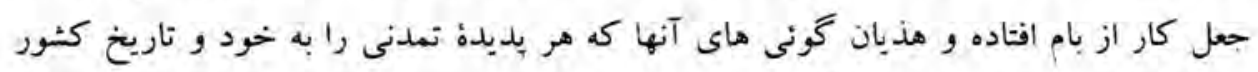
خود منسوب ميسازند، برملاء مبيخردد

ماخذ

1- عزيزى، نظرمحمد، باستانشتاسى افغانستان، جلد اول، |rN||

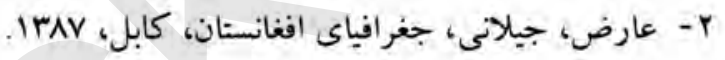

r- قادريان، عبدالصمد،(ميرزكه رويداد بزرگ در تاريخ افغانستان) كوشانيان، مجموعه

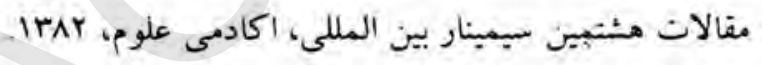

F- F كزاد، احمدعلى، تاريخ افغانستان، جلد دوم، كابل، Iro

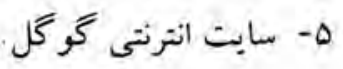




\section{سرمحقى ميرعبدالرووف ذاكر}

IraF الىهرست عناوين مضامين جاب شده در مجلات باستانشناسى از سالى

$$
\text { IV IFAF تور سوم، شعاره اول، جوز مسلسل }
$$

ييام وزير اطلاعات و فرهنگ و توريزم به مناسبت از سرگيرى نشر مجله علمى- تحفيقى

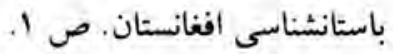

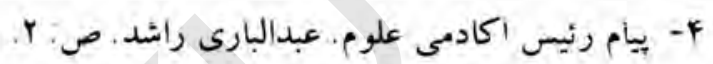

ه- باستانشناسى كليد معضلات تاريخ، محقى كتاب خان فيضى ص ص ب-F.

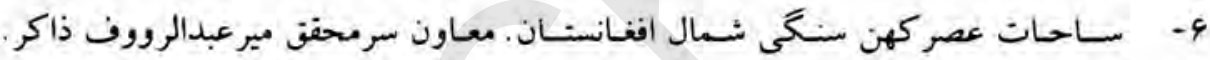

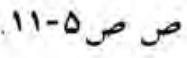

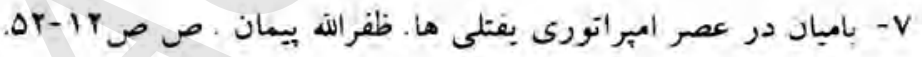

1- انتثـار دين بوديزم از بهارت قديم به كثـور هاى همجـوار محقق كتاب خان فيضى.

$$
\text { ص ص صr- }
$$

9- تائير فرهنگ يـونان بر فرهنگ كوشانى. معاون سرمحقف عبدالصابر جنبش.

$$
s r-\Delta s
$$

$$
\text { . 1- نبسا دشار مفهوم. يوهاند رازقى نهيوال. ص ص VY-AF. }
$$




$$
\text { ا - منار جكرى و اهميت تاريخى آن. محقق نسرين. ص ص س-VW. }
$$

با - كزارش علمى اولين دوره حفريات ساحه باستانى خواجه صفا، محقق محمد نادر رسولى.

$$
\text { ص ص ص. }
$$

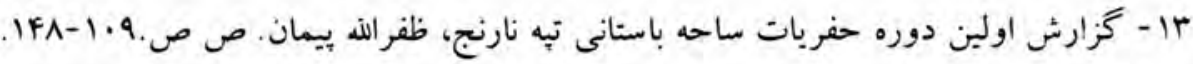

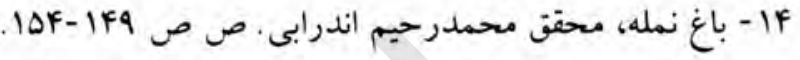

ها - اخبار فعاليت هاى انستيتيوت باستانشناسى بعد از آغاز اداره مؤقت الى اكنون، اداره

$$
\text { باستانشناسى ص ص ص. }
$$

\section{دور سوم، شماره دوم، قوس INAF نمبر مسلسل}

$$
\text { - - سر مقاله، محقق كتاب فيصى ص r-1 }
$$

r- تيكر هاى نوع يونانى در باختر زمين، معاون سرمحقق ميرعبدالرووف ذاكر . ص ص r-1. ז- آغاز كاوشهاى باستانشناسى دو كابيساى ديروز و امروز. معاون سرمحقق عبدالصابر

$$
\text { جنبش: ص ص }
$$

F- سـاحات عمده باستـانى دوران بـودايى شـهر كابل. يـوهندوى عصمت الله عثمانى.

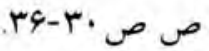

ه- منشأ اتنيكى كوشانيها و نظريات دانشمندان. محقق كتاب خان فيضى. ص ص FF-FV. 


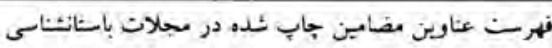

$$
\text { 4- تاريخ، آيين و زبان اوستاى در عهل زردشت خيرمحمد خيرزاده. ص ص FD. - D. }
$$

V- گزارش دور اول حفريات در قريه كنجكى اورياخيل بغمان (هارIrAf). ظفر بيمان.

$$
\text { ص ص ص }
$$

1- گزارش سروى حمام امام در شهر قديمى هرات. معاون محقق عبدالصمد قادريان.

$$
\text { ص ص }
$$

$$
\text { 9- اخبار باستانشناسى، اداره باستانشناسى، ص ص IIN-IIV }
$$

10-Bamiyan SousL/ Empire des Hephtalites. PP. 1-33. By Zafar Paiman

$$
\begin{aligned}
& \text { دور سوم، شماره سوم و جارم جوزا هArI. نمبر مسلسل } 19 \text { و.r. } \\
& \text { يادداشت ادارم، دفترمجله. ص r-1. } \\
& \text { r- مهر يا ستمب، معاون سرمحقن مبرعبدالرووف ذاكر. ص ص r- } 9 .
\end{aligned}
$$

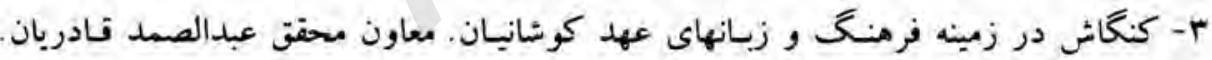

$$
\begin{aligned}
& \text { ص ص ص r.1.1. }
\end{aligned}
$$

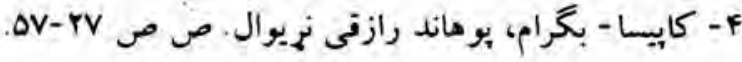

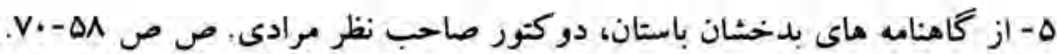


4- حصار كاليوين يـا قلعه نرتو معروف به قلعه نريسمان، معاون سرمحقق عبدالصابر جنبش. ص ص ص vi-vi

V- بالاحصار كابل و اطـراف آن از ديدكاه باستانشناسى، محقق محمدنادر رسـولى. ص ص ص מr-va

1- يول قديمى اندو -گريك در قندهار(Arachosia)، معاون محقق عبدالبشير حمبدى ترجهه:

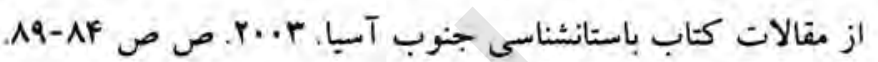

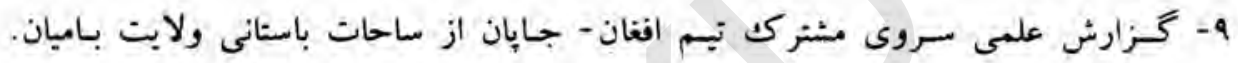
معاون سرمحقى عبدالواسع فيروزى و محقى كتاب خان فيضى.ص ص . IIr-9

. - "ززارش علمى دور دوم حفريات(Excavition) در تيه نارنج (كنار زيارت بنجه شاه)

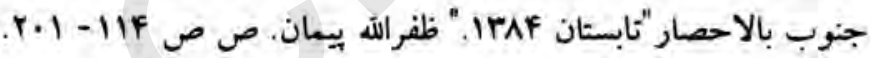

11 - گزارش سروى علمى تيم مشترك افغان- جايان از ساحات باستانى جنوب شهر كابل. معاون سرمحقى ميرعبدالرووف ذاكر و محقق كتاب خان فيضى. ص ص r.rA-r.r.

זا- گَزارش سروى و كاوشهاى مقدماتى تيم مشتركث باستانشناسان افغان - جايان در ولايت

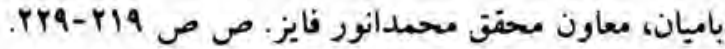

$$
\begin{aligned}
& \text { r - اخبار باستانشناسى. ص ص •rr-Ir. }
\end{aligned}
$$


14- Continuation of the prevuios Article. (-Bamiyan/Empire des Hephtalites).PP.1-22. . By Zafar Paiman.

دور سوم، شماره بنجم، سنبله IrA9

$$
\text { |- بادداشت ادارم، دفترمجله. ص 1- }
$$

$$
\text { r- هنر دوره اسلامى، معاون سرمحقق ميرعبدالرووف ذاكر ص ص r--1. }
$$

ب- ارهن (امـام صاحب) آبيـه باور هاى دينى و تـاريخى، داكتر مهندس صاحب نظر مرادى

$$
\begin{aligned}
& \text { ص ص } \\
& \text { F -F - دآى خانم شار، بوهاند رازفى نهيوال. ص ص .YV. }
\end{aligned}
$$

ه- شبيوه هاى تزئين در معمارى عصر اسـلامى افغانستان. يوهندوى محمدعالم فرهاد.

$$
\text { ص ص ru }
$$

9- قلعه اختيارالدين در بويه تاريخ، معاون سرمحقق عبدالصابر جنبش. ص ص Fq-FA

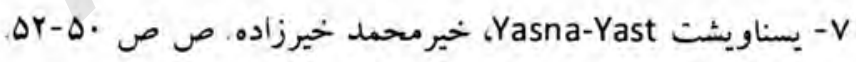

1- گزارش علمى سروى تيم مشتركث افغان - جايان از ساحات باستانى ولابات باميان، سريل جوزجان، بلخ و دره كاشان ولايت غور. معاون سرمحقق كتاب خان فيضى. ص ص صر هركي - 


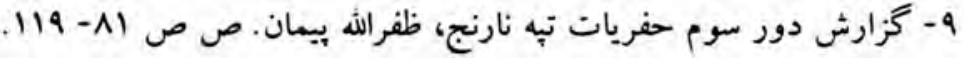

• ا- كزارش علمى تيم مشترك افغان- جايان از ولايت باميان، معاون سرمحقى

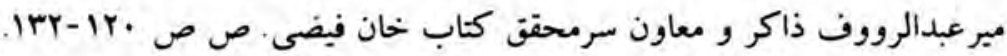

ال- تحليل مقايسوى معبد بودايى خرمنه غونلهى ولسوالى خو گيانى ننخرهار با حجره مدور تِه نارنج، معاون محقق نجيب احمد صديقى. ص ص ساI-1rی

12-Bamiyan 2006: The fifth Excavation Campaign of Prof. Tarzi Mission. PP. 116.

\section{Pور موم، شماره ششم، حوت IrA9}

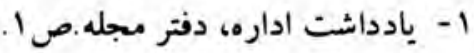

r- وطن زردشت (زاد گاه زردشت دركجاست؟)، داكتر مهندس صاحبنظر مرادى.ص r. r- كلتور باختر در عصر برونز، محقق محمدنادر رسولى.ص ص ro -III. F- نقوش ديوارى در افغانستان، معاون سرمحقى ميرعبدالرووف ذاكر. ص ص צr- צr. ه- د آى خانم شار ودانى، بوماند رازقى نهيوال. ص ص Fr - Tr. צ- مينار جام و اهميت تاريخى آن در فهرست آثار فرهنگى جهان، بوهنوال عصمت الله عثمانى. ص ص 


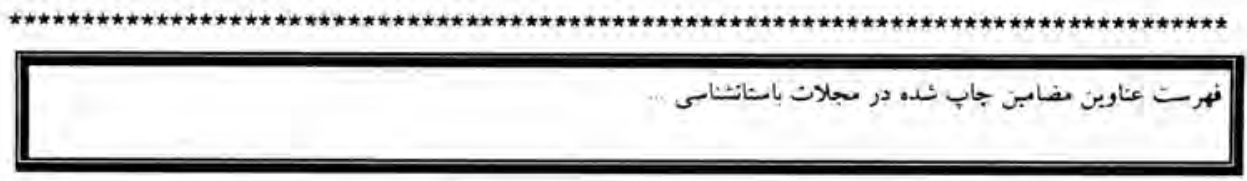

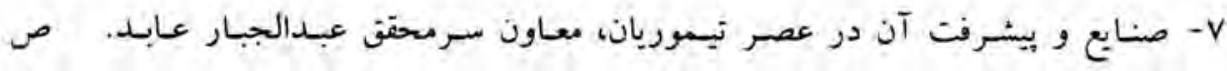

$$
\text { 9) - } \Delta F
$$

ه- باستـان شنـاسى و نقش آن در معرفى هويت فرهنگى و تـاريخى يـك كثـور معاون

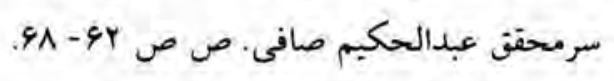

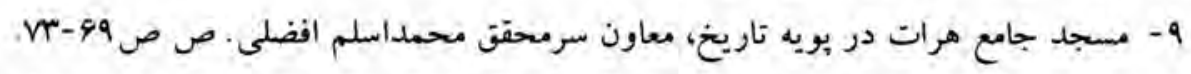

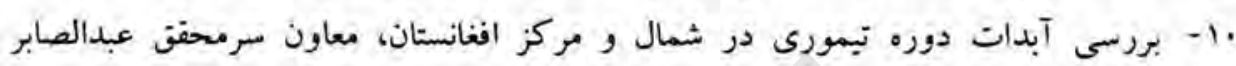

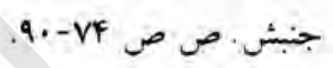

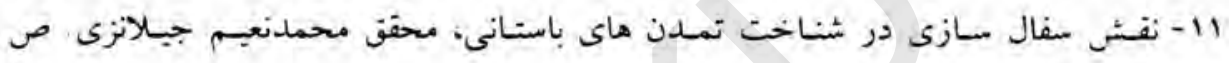

$$
\text { ar-91 }
$$

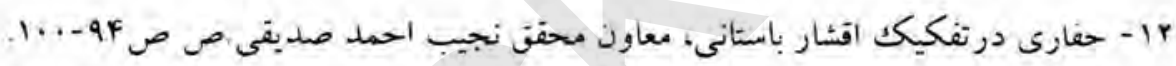

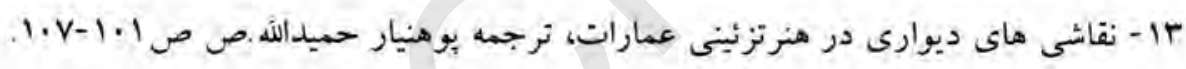

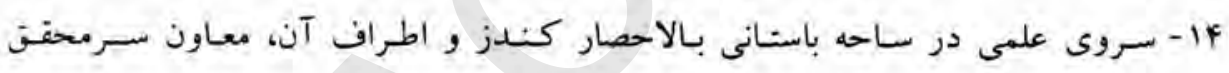

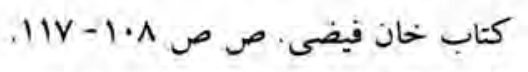

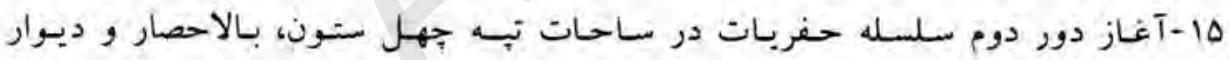

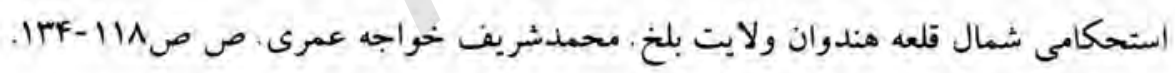

دورسوم، شماره هفتم، حوت IrAv

$$
\text { 1-1يادداشت اداره، دفترمجله. ص1 }
$$




$$
\begin{aligned}
& \text { r- دافغانستان يوه ماقبل التاريخى مهر . يوهنوال محمدرسول باورى ص ص r ب-N. } \\
& \text { r- موقعيت ايرياناويجه. داكتر مهندس صاحبنظر مرادى. ص ص بـ 9-10. }
\end{aligned}
$$

f- فعاليت هاى باستانشناسى در افغانستان و, برابلم هاى موجود در زمينه. سرمحقق

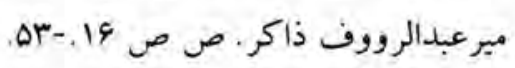

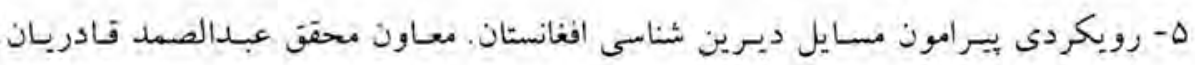

$$
\text { Q }
$$

4- انواع آبدات تاريخى باختر فديم در عصر برونز. محقق محمدنادر ربولى. ص ص1ه-

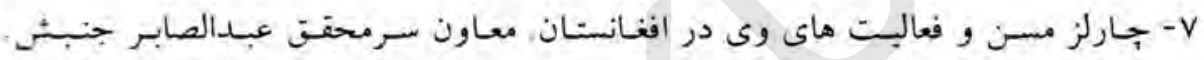

$$
\text { ص ص ص }
$$

$$
\text { 1- تاريخجه باغ جهل ستون. معاون سرمحقى زمرى كمال. ص ص IYF-110. }
$$

9- نظر كذرا بر يشينه تاريخى كاوشهأى باستانشناسى در بالاحصار بلخ معاون محقى فرهاد

$$
\text { ITF-Iro احمدى ص ص }
$$

10- Silan succinct de huit campagnes de terrain me nées dans la province de Bactres. PP.1-27. Par; R. Besenval et N. Rassoli.

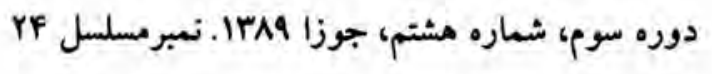

$$
\text { 1- بادداشت اداره. دفتر مجله. ص } 1
$$


r- انكشاف علم باستـانشناسى در روشنايى قرانكريم. الحاج بـوهنوال عصمت الله عثمانى.

$$
\text { ص ص ص }
$$

r- بلخ در برتو كاوشهاى باستانشناسى. سرمحقق ميرعبدالرووف ذاكر. ص ص rF-9.

$$
\begin{aligned}
& \text { F- دغزنى بودايى باجهى معبد. يوهاند رازقى نهيوال. ص ص هY-.r. } \\
& \text { ه- آثارباستانى وفرهنگى دوره غزنويان. معاون سرمحقق نسرين. اسب-FI. }
\end{aligned}
$$

4- قصر دارالامان يا آبده تاريخى دوره امانى. معاون سرمحقق زمرى كمال. ص ص صY Fr-AY.

$$
\text { Afni محقق شاغاسى سادات. ص ص }
$$

1- حفريات دور اول باستانشناسى در ساحه باستانى مس عينك لوگر . معاون سـرمحتق

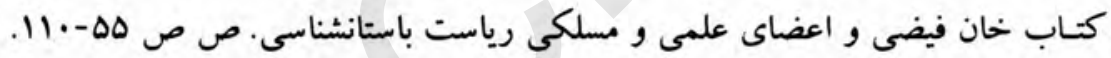

9- گزارش سروى علمى از ساحات باستـانى ولايت كنـدز. معـاون محقق فرهـاد احمـدى.

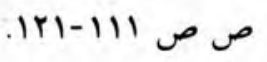

• ا- گزارش باز ديد از ساحات باستانى ولايت سمنگان. معاون محقق عبـدالصمد قـادريـان.

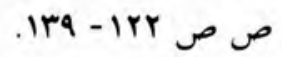




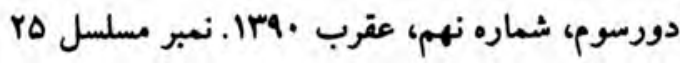

$$
\begin{aligned}
& \text { 1- يادداشت اداره. دفتر مجله. ص 1. } \\
& \text { r- اساطير بودايى. ترجمه: سرمحقق ميرعبدالرووف ذاكر. ص ص r-r. }
\end{aligned}
$$

r- تاثير هنر هلنستيك بالاى آثار مكشوفه ساحه باستانى مس عينك ولايت لوكر. معاون

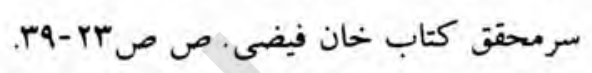$$
\text { F- ارخيوزلوزى (ذزيولرغونيوهنه) خه شى ده؟. ترجمه باورى. ص ص .FI-F. }
$$

ه- كابل تاريخى و داشته هاى تاريخى آن. محقق محمدنادر رسولى. ص ص

9- مقابسه آنار مكشوفه ساحه باستانى مس عينك با ساحات همجوار. خواجه نادرشاه و

$$
\text { عبدالقدير تيمورى.ص ص W- WV }
$$

V- روش هاى تعيين تاريخ در باستانشناسى. معاون محقق محمدانور فائز ص ص A صA VA. 1- منـار جـام شهكار معمارى عصر غوريان در افغـانستـان. معاون محقـق فـرهـاد احمـدى.

$$
\text { ص ص . } 1.4-9
$$

9- تفكيك مواد و ساختمان ظروف سفالى دوره كوشانى و ماقبل آن. معاون محقق غلام

$$
\text { حيدر كشككى. ص ص مص و.1.-11. }
$$




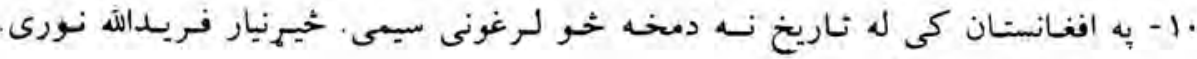

$$
\text { ص ص ص }
$$

ال - گزارش مختصر حفريات و سروى تيم مشترك باستانشناسى افغان - آلمان در ولايت

$$
\text { هرات. معاون محقن نجيب احمد صديقى. ص ص |r||-||ra. }
$$

rا - كزارش دوره دوم حفريات مس عينك. معاون سرمحقى كتاب خان فيضى، سرمحقى

$$
\text { مير عبدالرووف ذاكر و محقق محمدنادر رسولى. ص ص .|Fr-IF. }
$$

13- Kapisi Begram3: Renewing its Dating By.Shoshin Kuwayama Kyoto University.PP.1-28.

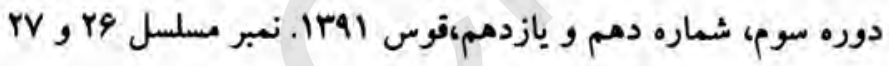

$$
\text { ا- إدداشت اداره. دفتر مجله.ص }
$$

r- بابر، كابل و كاوشهاى اخير در باغ بابر . سرمحقن ميرعبدالرووف ذاكر. ص ص r-ه r- مقايسه آثار مكثوفه مس عينك لو گر با آثار بودابي سوات معاون سرمحقن كتابخان

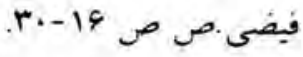

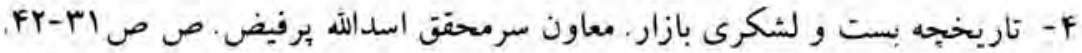

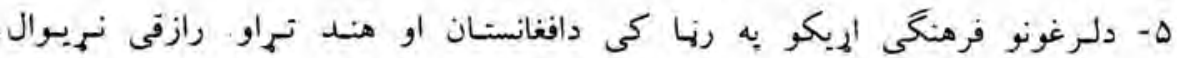

$$
\text { Q. }-\mathrm{Fr} ص
$$


4- مراكز مهم ادارى و برخى از قلعه هاى استحكامى دوره غوريان. محقف فايقه لحظه.

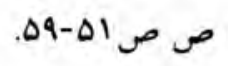

V- هنايانا و مهايانا در كيش بودايى. محقق فرماد احمدى. ص ص. .4-49.

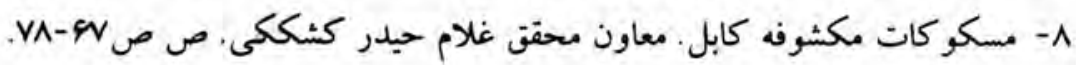

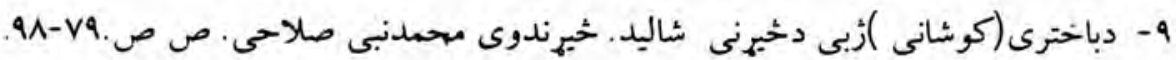
•ا- مفهوم شهر و سير شكل گيرى آن. معاون سرمحقى محمد شفيع غنى بئوهش.

$$
\text { ص ص }
$$

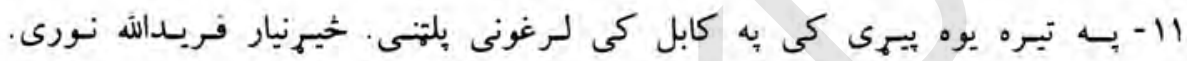

$$
\text { ص صמוflif }
$$

rا- كاوشهاى باستانشناسى در اطراف مصلى(ميناره) هرات. خيرمحمد خيرزاده.

$$
\text { ص ص DIF-ITF }
$$

rا - گزارش دور سوم حفريات ساحه باستانى مس عينك لوگر. معاون سرمحقق كتاب

$$
\text { خان فيضى، ص ص rmar-10rion. }
$$

14- Built heritage in Afghanistan: threats. Challenges and conservationBy: Abdul Wasay Najimi.PP.1-51.

دوره سوم، شماره دوازدمم، جوزاى YArا. نمبر مسلسل YA

$$
\text { 1- يادداشت اداره. دفتر مجله. ص1 }
$$

r- نظرى بر ساحات باستانى مس عينك لوكر. سرمحقى كتاب خان فيضى. ص ص If 
r- كاوش هاى مستقل باستانشناسى در ساحه كابل. سرمحقق ميرعبدالرووف ذاكر.

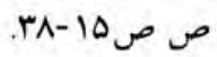

F- اوستا كهن ترين گنجينه خطى در تمدن آريايى. يوهاند دوكتور محمدحسين يمين.

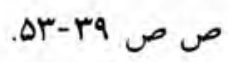

ه- دست آورد كاوش هاى مس عينك ولايت لوگر. محقق نجيب احمد صديقى.

$$
\text { ص ص (1) }
$$

9- فروياشى و اضمحلال غزنويان. سرمحقق عبدالجبار عابد. ص ص VA-GY.

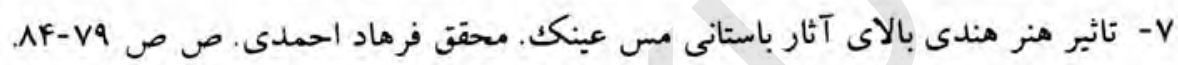

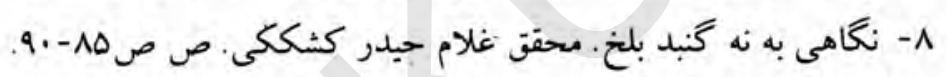

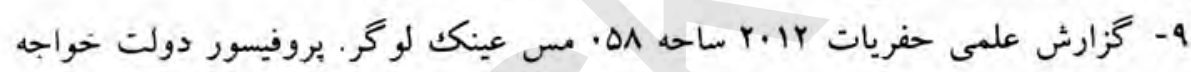

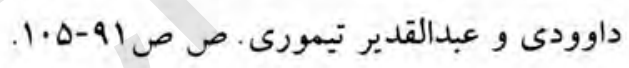

•ا - تاريخجه سروى و كاوشهاى باستانشناسى در ولايت ننخرهار . محقق شاغاسى سادات.

$$
\text { ص ص }
$$

11-گزارش دور اول علمى كاوشهاى جديد اطراف مينار هاى غزنى. خيرمحمد خيرزاده.

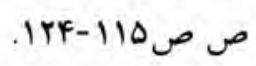

rا- دلوگر او خروارو او دگرديز دبالاحصارونو دجورشتونو يونانو باخترى لم گدى او

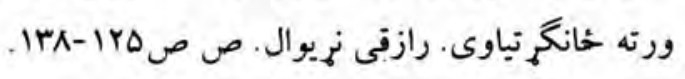


دور سوم، شماره سيزدمم، قوس rara

ا- يادداشت اداره. دفتر مجله الف.

Y- تخارستان - بدخشان كانونهاى زنده گى انسانهاى عصر باستان در كشور ما. دوكتور

$$
\text { صاحب نظر مرادى. ص ص آI- IV- }
$$

r- غزنه در آثار مؤرخين، جغرافه نغاران و جهانگردان. سرمحقق ميرعبدالرووف ذاكر.

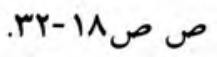

F- سروى و تحقيقات جديد باستانشناسى در ولايت غزنى. سرمحقق كتاب خان فيضى

$$
\text { ص ص PA-MT }
$$

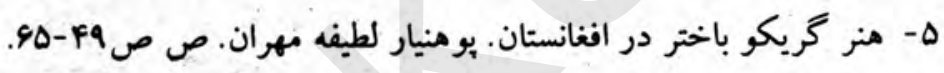

4- رابطه علم انسان شناسى با باستانشناسى، تاريخ جغرافياى انسانى، روانشناسى و جامعه

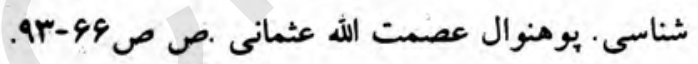

V- دعينك دمسو دكيندنو زغورنه. نوشته كايكوكين مترجم: ن. سوبمن منگل.

$$
\text { ص ص }
$$

1- هنرگريكـو بوديك مـولود امتزاج دو مكسب منرى. محقـق فرهاد احمـدى.

$$
\text { ص ص }
$$

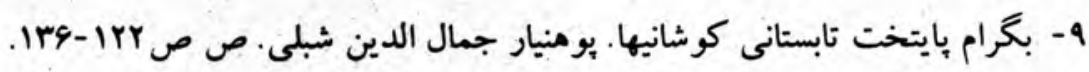
• ا- دافغانستان به فرهنگى بديدو كى ديونانى اغيز منى. شحيرنيو. رازقى نهيوال.

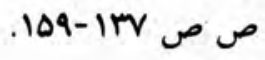


11 - تحقيق ساحوى از دور ششم ولابت باميان. محقى شاغاسى سادات. ص ص •19F-19.

\section{دوره سوم، شهارن جهاردمم، جوزاى IFAF}

$$
\text { ياداشت ادارم، دفتر مجله. ص الف. }
$$

ا- مورو له كومه خخايه راغلي يو، ليكوال:Jamie Shreeve ريسارونكى: ربول باورى.

$$
\text { ص ص ص مص }
$$

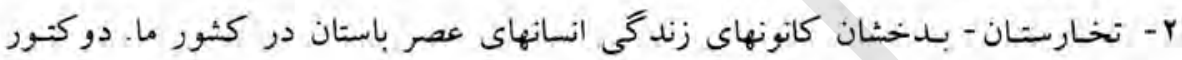

$$
\text { صاحب نظر مرادى. ص ص ص r If If }
$$

r- هنر و صنابع دستى عصر صفوى ها، سرمحقق عبدالجبار عابذ ص ص ص عب- 09. ع- اثيراث هنر اسلامى بالاى معمارى هندى. سرمحقق مير عبدالرووف ذاكر . ص ص .4-

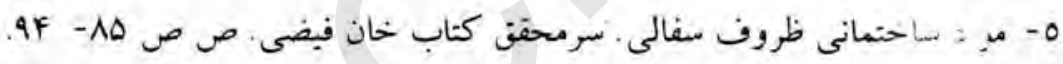

T- نگاهى به هنر معمارى دوره غزنويان. محقى نجيب احمد صديقى. ص ص

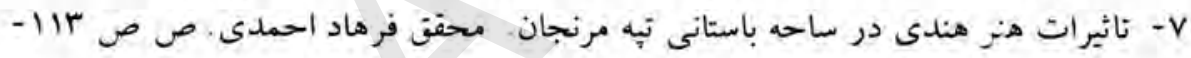
Irr

1- صنايع ظريفه افغانستان قديم محقق شاغاسى سادات. ص ص IrV-ITF.

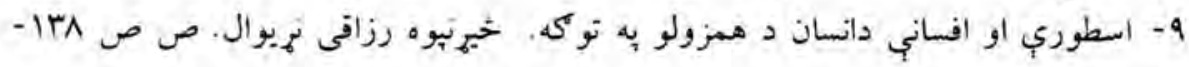

• ا-كزارش تحفيقى از اطراف مينار هاى غزنى. خيرمحمد خبرزاده و محمدشريف خواجه

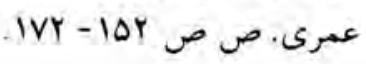




\section{Results of the last Archaeological Excavations in Ghor Province}

Written by: Associated Professor Ketab Khan "Faizi"

Translated by: Abdul Khalid "Khursheed"

Ghor ancient province is one of the central province of Afghanistan, with $39666 \mathrm{~km}$. This ancient province is the higinest portion of Afghanistan after height level of Pamir and Baba Mountain is snowy and tossesses cold winter with ups and downs valleys.

The center of this ancient province is Chagcharan and contain 9 districts and more than 10 administrative units.

During the pre-historic time the famous and historic cities are Firoz Koh. Tolak, Ahangaran, (the last capital of Ghoris kings upper Harirod river) and other several centers inGhor. In the pre historic time after the formation of population, had nature forces worshiping religion. This Province administrated by governmental local law. Condition of geographicalzonekept it from every penetration and domination of neighboring zone. Zorozstrian religion begun in the main center Balkh in the $7^{\text {th }}$ B.C and that reached Ghor after the down fell of Bactrian state and penetration of Akhamanid in Afghanistan, contrary to other parts of the country, the parasol of its high mountain and tearful valleys could save its freedom. By entering of Alexander the great all ordonnances and regulation of Ghor has fallen and its army passed Ghor. Ir this historical period Ghor joined to uplift and development and after that Buddhist religion at its eastern lands penetrated and the people of Ghor iurned co a new culture like Greek-Buddhist. Buddhist religion prolonged till spreading of Islam religion. During Buddhist governed in Afghanistan form Kushanids until Turks and

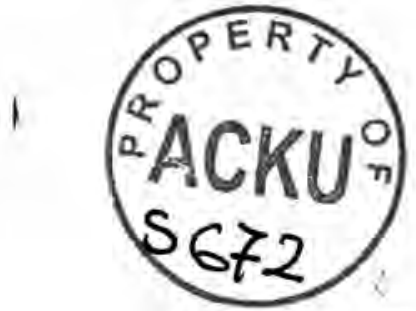


Sassanid. But Ghor province never came under domination of any power and stayed independently. Progress and civilization of Ghor with its domestic independence continued till spreading of Islam religion, after that entered to a new destiny the destiny which covered all parts of Afghanistan.

After spreading of Islam, Ghor province confrontedto a torrent which is mentioned by historians of east and west, and the strong mountainous fortof Ghorstand against barbaric Mongols armies, resisted a difficult war and perished several elders ofMongols army. Mongols had to use all their barbaric forces to this province like other parts of the country. Like this their plan accommodated and all historic and cultural constructions ended and destroyed. However Ghor province as the heart of Afghanistan had key role in the historic pages.

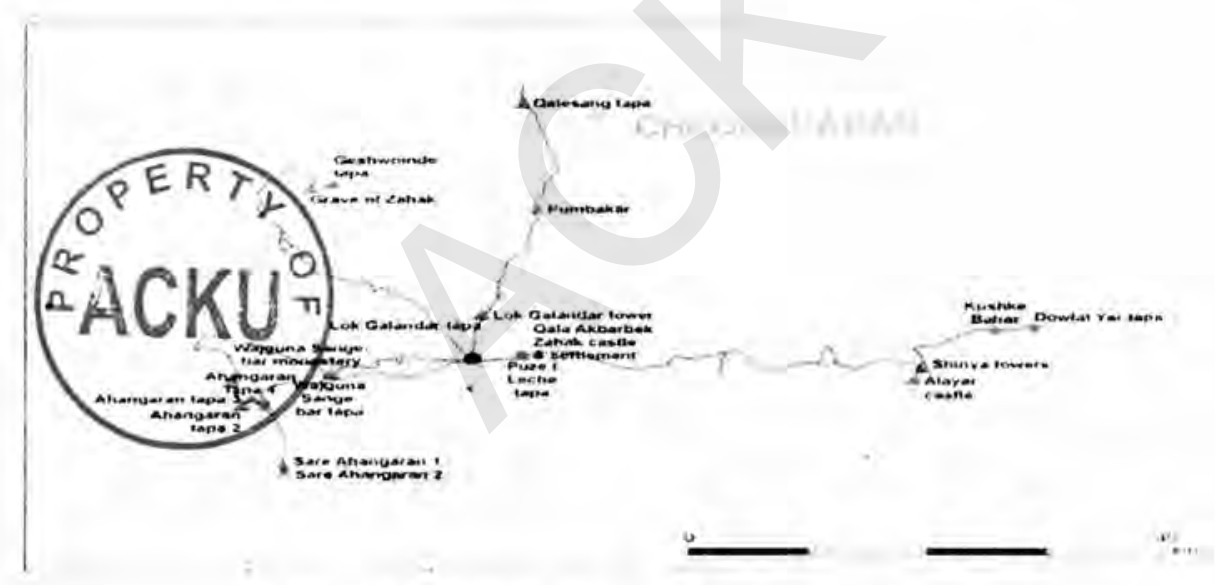

General plan of Ghor province and ancient sites.

Because the main title of our issue is archaeological research, therefore we paid attention to introduce sites and monuments of this province. 
A: survey of archaeological and historical sites of Ghor province after interim government of Afghanistan until now:

Survey of archaeological province of Ghor started in 2002, 2003, 2005, 2007, and 2008 A. Dby joint team of Afghan-Italy- London Cambridge and Lithuania.

\section{Firoz Koh:}

This survey is done at the hilltop of Firoz-Koh(Firoz Mountain) and around Jam minaret. The site is indicated and photographed on archaeological map. During the survey of archaeologists on Azad Mountain south of Jam minaret illegal excavations seemed which have done in several parts of it and remains of Islamic potteries with enameled and without enameled with different painting designs which had black colors and remains of colored glasses owned white colors, discovered.

\section{Kushk:}

This ancient site located at the pathway of Jam and Herat, around $2 \mathrm{Km}$ south of Jam minaret. In this site there are graves of Jews at the mentioned site were villages and people have lived there. Far from this site there were brick kilns, which probably, made for Jam minaret construction, discovered bricks are belongs to Ghorid period.

\section{Ancient site of Kushk Bar:}

Ancient site of Kushk Bar situated at $47 \mathrm{Km}$ east of Chaghcharan city and containing around 17 hectare lands. This site located at a distance $5 \mathrm{~km}$ of Doulatyar from district. Kushk Bar ancient site was a populated site probably, Was the capital of kings. In this site round towers seems, probably made for protection of the city. In this site illegal excavations have done and remains of 
potteries are seen on the site and also pottery kiln discovered from the site. Professor Alexi believes that the site was a big city and possess relics belong to different period of Neolithic, Bronze and Islamic period. In this site illegal excavations have done but, professor says that at the button of site there are remains of relics.
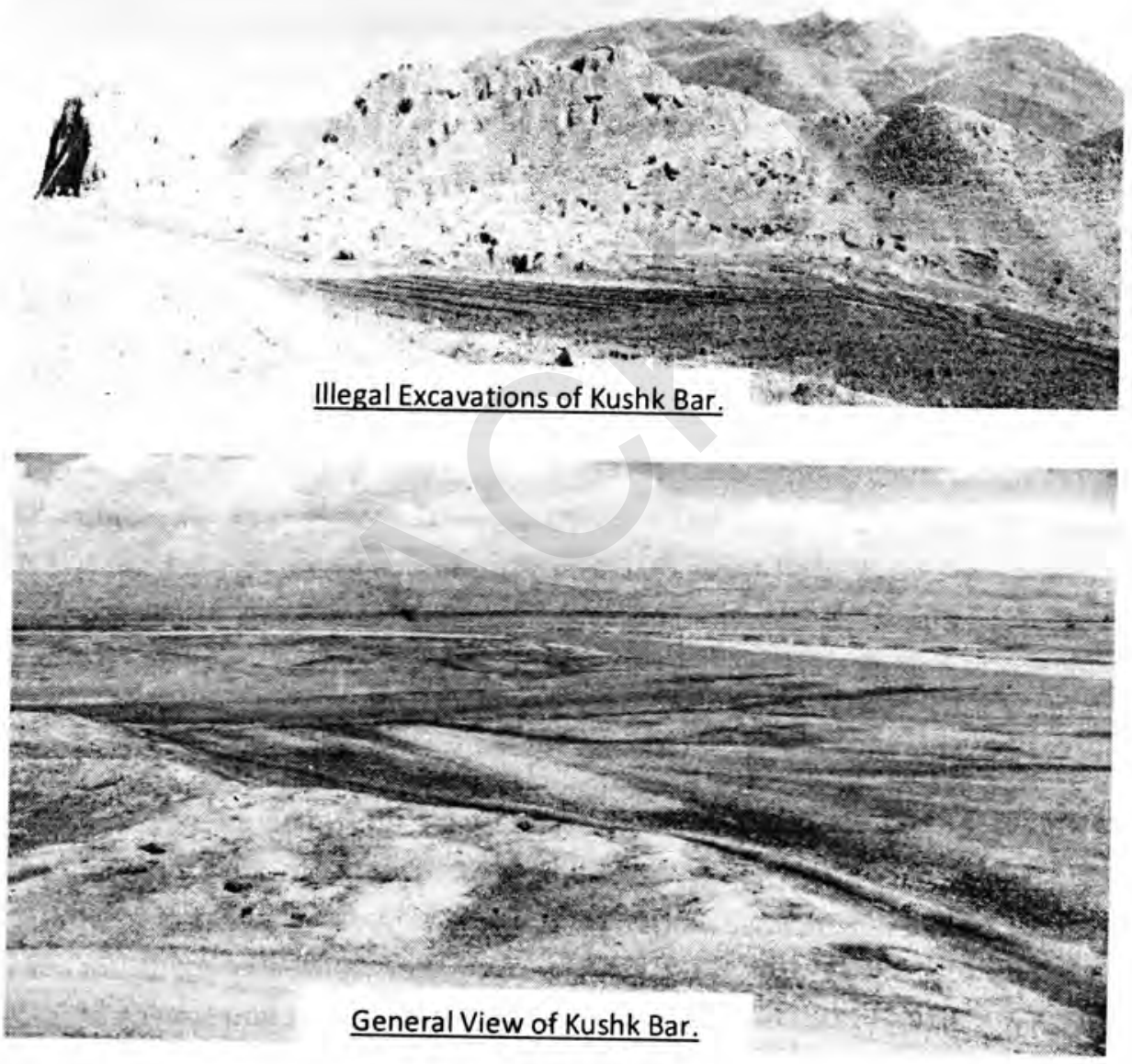


\section{King's Daughter Palace Mountain:}

Located at the north part of Jam minaret and east of Baydan village, own $2500 \mathrm{~m}$ height from sea level and is most difficult to pass. At the upper part of it there are fewerre mains of constructions. This site excavated by unknown and irresponsible persons beforehand. At this site there is a pool from baked mud brick, length $8.2 \mathrm{~m}$, width $5.6 \mathrm{~m}$ and depth $4.5 \mathrm{~m}$. The measures of bricks are $4 \times 22 \times 22 \mathrm{~cm}$. South part of this pool is circular and at the north part there is a prism of extra water exit from it. From this site remains of potteries and glasses are also found.

\section{Shena village:}

This site situated at forty $\mathrm{km}$ northwest of Chagcharan city, 34degree, 30 minutes and 31.6 seconds north latitude, 65 degree, 40 minutes and 20 seconds east longitude and own 2418 height from sea level. At the upper part of this mountain two have been constructed stone towers, , their measures are $6 \times 3 \times 3 \mathrm{~m}$ and have defensive arrows, these towers are belong to Buddhist and Islamic periods. Thus, in the Shena bazaar there is a brick bridge, that constructed by baked mud brick, measures $7 \times 21 \times 35 \mathrm{~cm}$, length of this bridge is $18 \mathrm{~m}$, width $7 \mathrm{~m}$ and construction material are mud and lime. There is also a bridge reconstructed in a Shena bazaar. Now it is not useable.

\section{The Ahangaran fort:}

This monument situated at $28 \mathrm{~km}$ west of Chagcharan city at 33 degree, 28 minutes and 36,5 seconds north latitude and 65 degree, 2 minutes and 74,9 seconds east longitude and own 2203 height from sea level. Ahangaran fort invaded several times by Sultan Mahmood Ghaznavi's son and with 4000 army was defeated and next time with 12000 army conquered it. At this site there are five ancient hill by different distance and the of discovered evidence show that 
this site is belong to Buddhist period the remains of potteries certify our speech. In addition to these remains Bricks with measures $10 \times 15 \times 38 \mathrm{~cm}$ also discovered. This site excavated illegally.

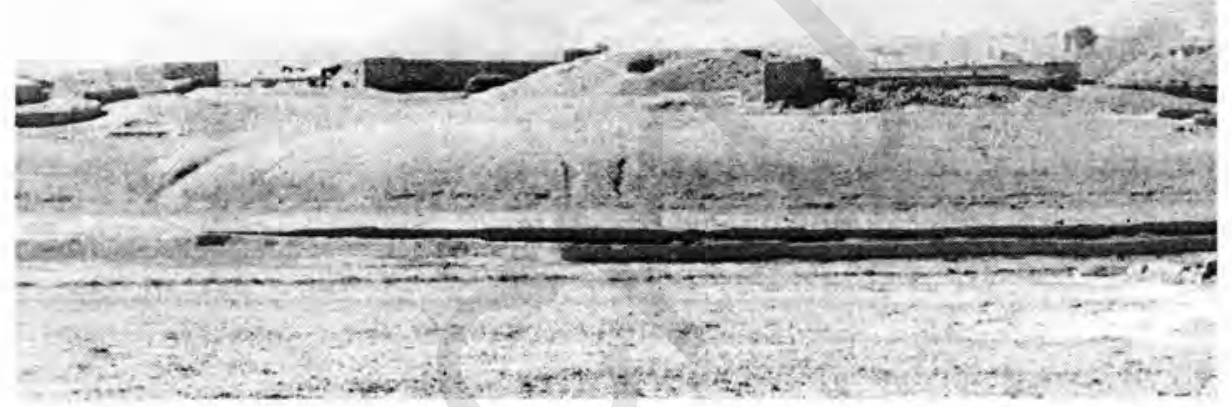

Ahangaran fort.

\section{The village of Shaikh Khan Kawosi:}

Shaikh khan Kawosi ancient site situated at the heights and located at 34 degree, 34 minutes and 37.2 seconds north latitude and 65 degree, 15 minutes and 99.1 seconds eastlongitude. This site own $2393 \mathrm{~m}$ height from sea level. At the mentioned site there is a square tower, the height is $4 \mathrm{~m}$, probably this site belongs to Islamic period. At a distance of hundred meters north of it there are visible some constructions. These constructions excavated illegally and broke 
down and named as Laki Qalander and according to archaeological researches by Professor Alexi of Lithuania's university this site belong to Kushanid period.

\section{Wazhgon Sangbar:}

This ancient site located at the west of Chagcharan and has historical and monuments sites. On the base of discovered evidence this site used by ancient people and has ancient caves and are the same as Yakawolang Bamiyan province caves.

Caves of this ancient site carved in the rocks, the number of these caves are 6 . At the one of these caves, there is one niche made for lamp and one is like drinking place probably, they put their dead over there it. As saying of Professor Alexi and according to discovered evidence from this site probably, it is belong to Buddhist period. At the site of Sangbar illegal excavations also have done and caused destruction of buildings.

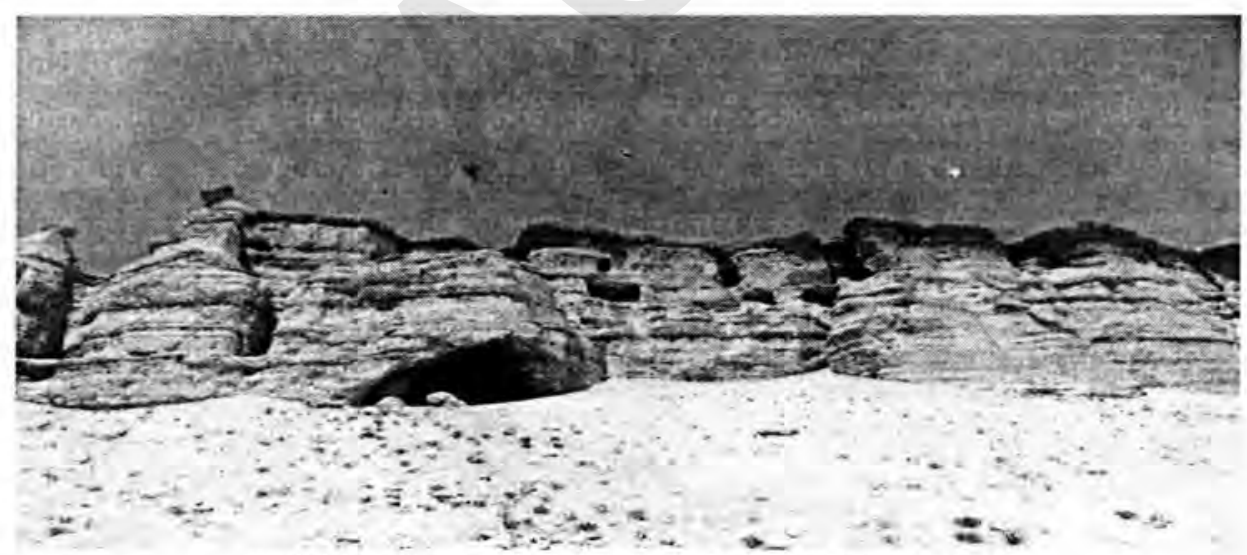

Buddhist caves period Wazhgon Sangbar first century. 


\section{Zahak fort:}

Zahak historical monument is situated at a distance of five $\mathrm{km}$ east of Chagcharan city. At34 degree, 31 minutes and 57 seconds north latitude and at 45 degree, 28 minutes and 18 secondseast longitude and own $2283 \mathrm{~m}$ height from sea level. This monument surveyed by joint archaeological Afghan and Lithuania team. In addition of this site, another site named Poza Lech also surveyed probably, has 1000 years history. This monument has thick wall there is a saying that three acquired horses from this site could pass on the wall at the same time. In the course of time this wall destructed, Remains of pre Islamic period are. Probably have 2500 years history, this historical monument destructed by Genghis Khan in 1222.

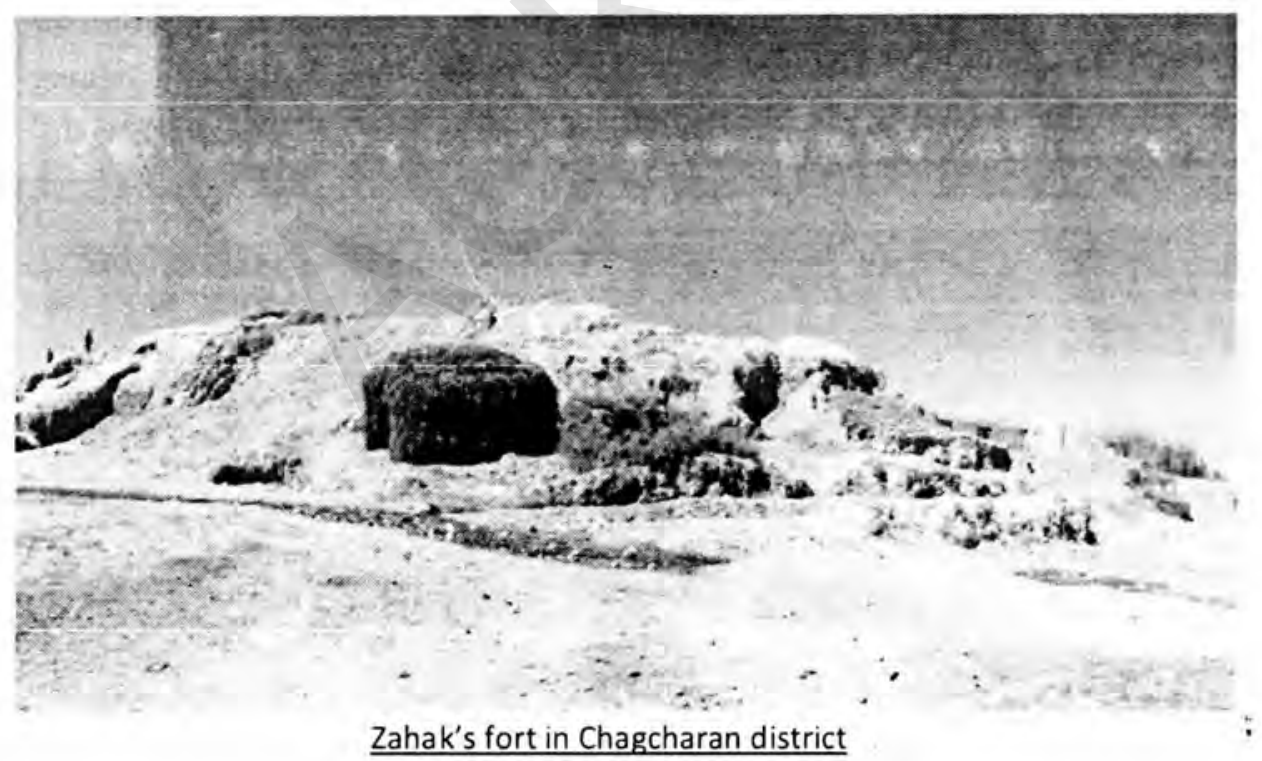




\section{Ancient sites of Zahak fort:}

Zahak ancient site fort is situated at the west part of a muddy hill at a distance of more than $100 \mathrm{~m}$.it is excavated by irresponsible persons, hence remains of potteries exists on the site. Now this site uses as domestic animals protection house. The mentioned site is outside of Zahak fort.

\section{The surrounding of Kushkbar:}

Around Kushk bar illegal excavations also have done. Signs of archaeological sites exist on the site. And it seems that ancient people lived togetherin this site and by the coming of Mongols destructed in 13 century A.D. and up to now no one lives there and it is abandoned.

\section{Ancient site of Ponba Kar:}

A site at the distance of $25 \mathrm{~km}$ north of Chagcharan city named Ponba Kar. This ancient site is one of the famous sites of Ghor province. This site is situated at 34 degree, 41 minutes and 57, 5 seconds north latitude and 65 degree, 19 minutes and 123 seconds east longitude and own 2553m height from sea level. North parts of this site is surrounded by Ghalmin village, the shrine of Jahan Numa and south of Kawosi village, east a soil hill or Lalmy Kari to the east and Charsada district is located to its west. This site excavated illegally and on the base of discovered evidence probably, belongs to Iron Age similar to Mandigak 3-4 B.C. also relics and signs discovered which belongs to 4-3 B.C. and on the base of discovered relics from the site, this site once again filled with sediments and is capable for agriculture and need to be excavated legally.

The main ancient site of Ponba Kar located on the hill which is approximately hundred acre lands. During survey in the site two Jugs of potteries are founded 
Probably, belongs to Iron Age. The potteries kept in the Institute of Information and Culture in Ghor province.

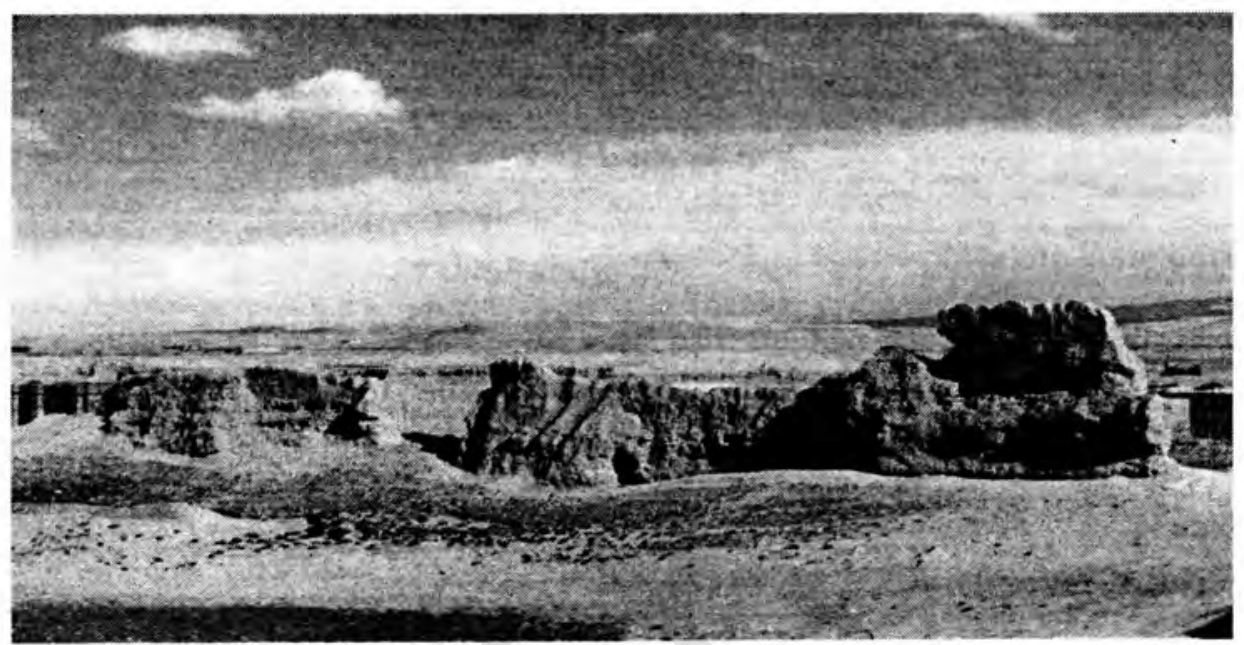

\section{Akbar Beg Zahak fort.}

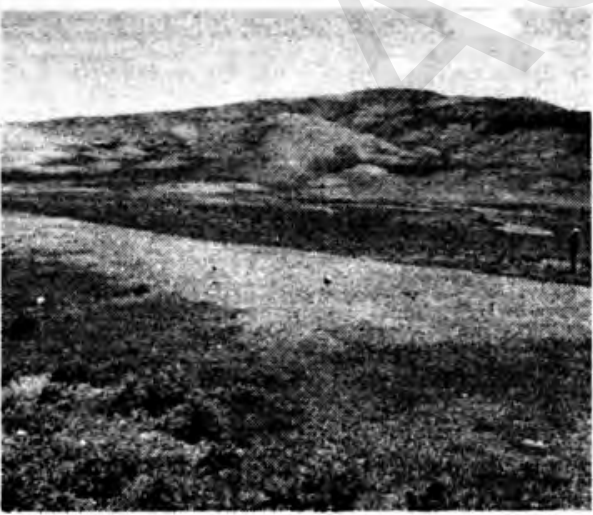

Archaeological site of Ponba Kar

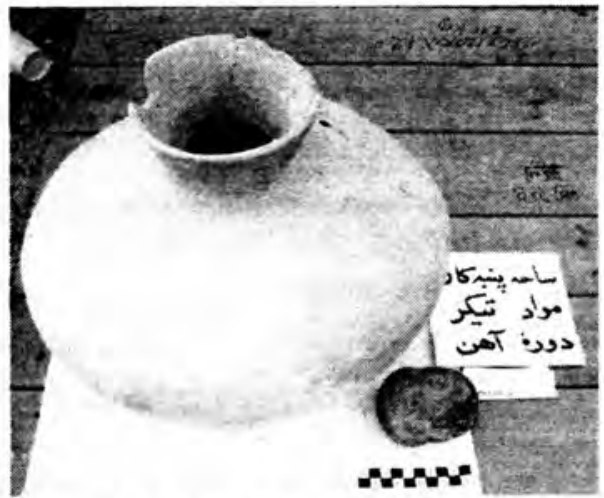

Jar pottery from Ponba Kar 


\section{Ponba Kar surrounding sites:}

Based on the survey of the Afghan and Lithuania teams around Ponba Kar, there was remain of wall that now destructed and around that two soil hill exist which to belong, Buddhist stupa period. The site surveyed and registered by joint Afghan and Lithuania team.

\section{Zahak's grave ancient site:}

Zahak's grave Ancient site own $3100 \mathrm{~m}$ height from sea level. $50 \mathrm{~km}$ far from Chagcharan city, situated at the place called Jar Chuqhor at a high round hill and the highest area of Ghor province. As result of illegal excavation at the site remains of potteries discovered, according toProfessor Alexi view, probably the site has $\mathbf{3 0 0 0}$ years ancient history. He mentioned that in this site Zahak's grave is existed but, until professional digging that we cannot say that this would beZahak's grave.

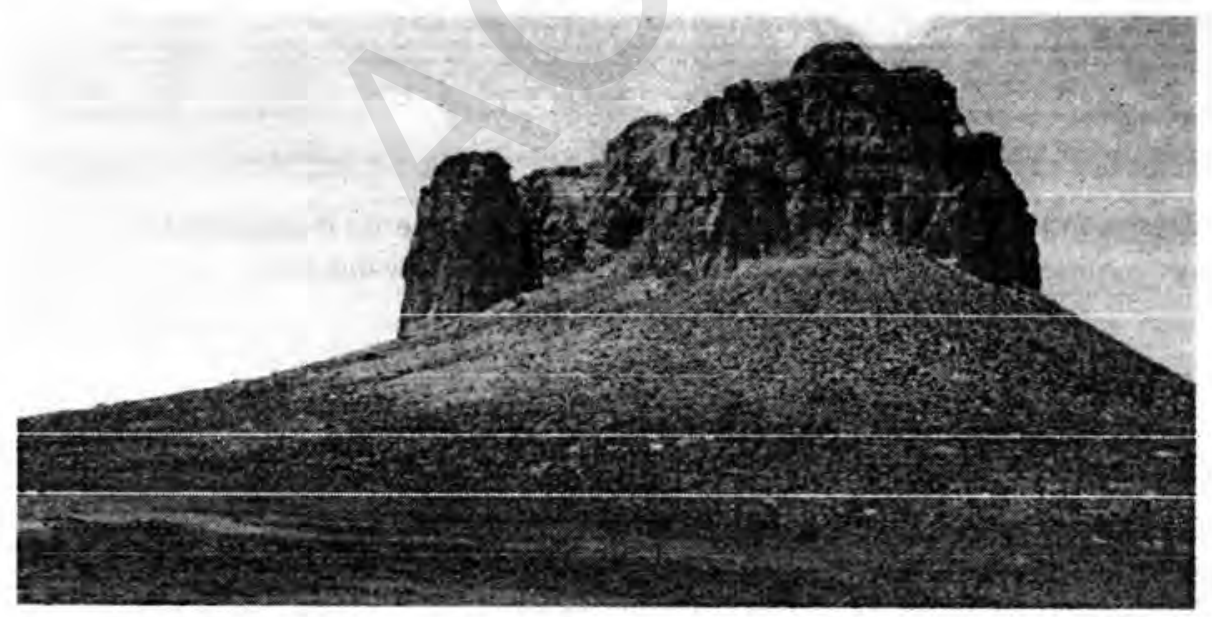

Zahak's grave site. 


\section{Zahak's prison:}

At the upper point of the hill there is a site, famous as Zahak's prison. This site had more depth but during times, due to falling of mud and stone by rains and local people it filled completely.

\section{Payshwandi hill:}

This ancient hill has about one $\mathrm{km}$ distance from Zahak's grave, to east of that situated a village, the site illegal excavatedand its exact history is not cleared.

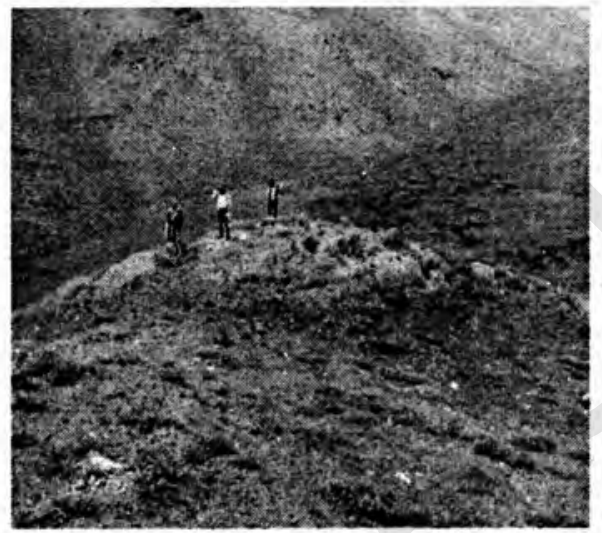

Payshwandi hill Ancient Site.

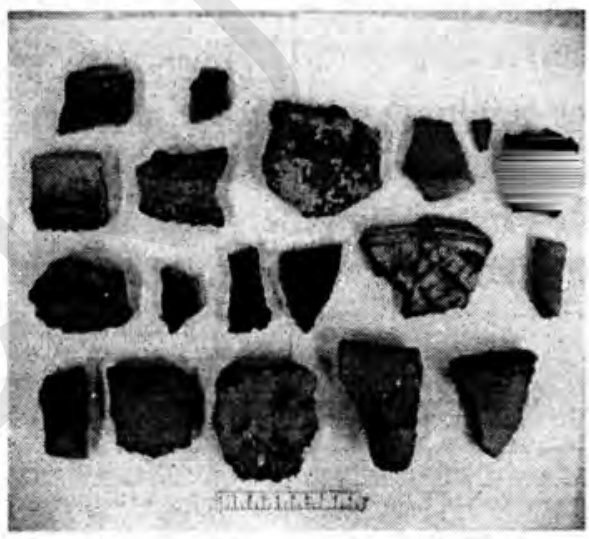

Remains of potteries discovered from Payshwandi hill.

\section{Malik Anter fort:}

This historical monument situated at $35 \mathrm{~km}$ west of Chagcharan city, the center of Ghor between mountains and middle of valley. Among local people it is famous as Malik Anter fort. Agricultural lands, mountains surrounded the site and own $2270 \mathrm{~m}$ height from sea level. At the site seem towers and east of this 
monumentstone picturesare carved which its width is $70 \mathrm{~cm}$, height $43 \mathrm{~cm}$ and at the side of the carved picture there is another one which has $10 \mathrm{~cm}$ width and $40 \mathrm{~cm}$ height. This site has about $50 \mathrm{~m}$ height and containing 500 meters square land. The site is enclosed by 35 meters long stone wall and has four towers. The construction materials are mountainous stone and mud that joined every tower. In addition, it is built with pakhsa wall (mud wall) that has three meter width.

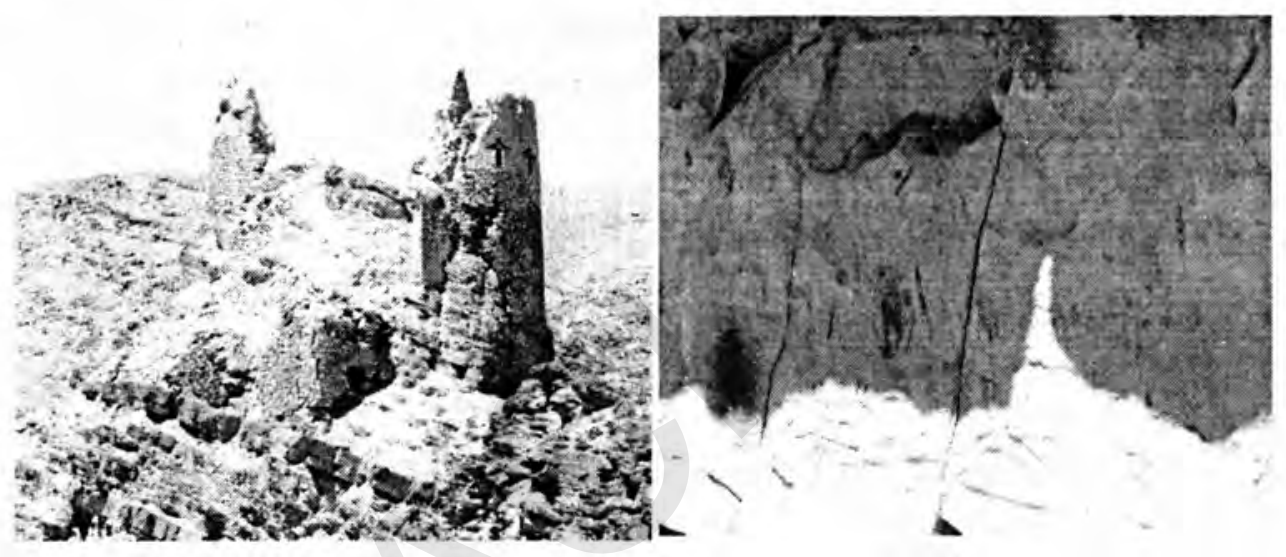

Carved rocks at Malik Anter fort, 6-14 century A.D.

\section{B: Excavation:}

Excavation performed at some parts of Ghor province by Afghan-Italy and Afghan-London Cambridge joint archaeological teams. These excavations are: 


\section{1- Around Jam Minaret:}

Primary excavation of this site started in August 2003 A.D by joint Afghan and Italy archaeologists. Based of the excavation at this site, after $1,75 \mathrm{~m}$ depth regular floor surface of a Madrasa (place of Islamic teaching) was apparent, bricks measures $14 \times 25 \times 25 \mathrm{~cm}$ used in this floor and this floor have continued.

At the east part of Jam Minaret in a space of $90 \mathrm{~m}$ at the coast of Harrirod River, primary experimental trench excavated, the goal of this excavation was finding of Madrasa surface and mosque which had connection to minaret. By the practical work development, bricks and plaster discovered, these were not on its original place and felled down. Another trench in space of $7 \mathrm{~m}$ excavated into west of the minaret, length $4 \mathrm{~m}$ and width $1,50 \mathrm{~m}$.

Also due to excavated trenches at the sections of $A$ and $B$. at the $127 \mathrm{~cm}$ depth, a regular floor made of baked brick measures $25 \times 25$ and $24 \times 24 \times 5 \mathrm{~cm}$ discovered. So round decorated baked brick like four flower leaves and with decorated sides like cylinder from small scraped bricks with less number of enameled and without enameled potteries are founded.

Also on 24 of the August 2005 another trench opened to the west of section B means through minaret. In this section Madrasa surrounding wall, its floor made of bricks seemed. And also pakhsa wall seemed. In all part of the mentioned sections remains of surrounding wall of Madrasa floor specified, in some parts there were scrapings because of foundation stone excavated to $220 \mathrm{~cm}$. another trench to the southwest of $C$ trench in space of about $9 \mathrm{~m}$ measure $1 \times 2 \mathrm{~m}$ excavated, that certainly after $61 \mathrm{~cm}$ a baked brick floor similar to other trenches found, The surface of bricks due to moisture it had pelts.

At the northeast of Jam the Minaret beyond Harrirod River at the slopes of Firoz Koh another section measure $1 \times 4 \mathrm{~m}$ opened, in cause of that living house 
discovered. At the northeast part of that ashelf is founded, the foundation is with stone and on the top, bricks and plaster are used, small fuel pottery lamps which, in some parts of it scorch see meddecorated woods, bones, remains of enameled and without enamel and coal discovered. This living house made dome like and excavated earlier by irresponsible people.

Khar Khuj and slopes of Firoz Koh:

In a place named Khar Khuj which is situated about $1.50 \mathrm{~km}$ south of Jam Minaret and at the slopes of a mountain at the south route and Heart .Earlier that the site was excavated illegally.

As cause of survey at Firoz Koh sites, a number of bones, remains of potteries, baked bricks, woods, a piece of copper, cereal, mud and a brick stove discovered and carried to Kabul in order to certify its date and then to London. The main findings are a fuel lamp, an iron needle and a round coin carried to Kabul and submitted to national museum also two round Islamic coins small and big during excavation in $\mathbf{2 0 0 3}$ are founded and submitted to national museum. 


\section{References:}

Ghobar, 1384 H.D (2005A.D).

1- Mir Ghulam Mohammad Ghobar, "Historical Geography", Second Publication, Maiwand Printing House, Page145-149.

2- Scientific report 1384H.D (2005A.D).

Scientific report of Afghan-London Cambridge Team, Archaeology Institute Archive.

3- Scientific report 1386 H.D (2007A.D).

Scientific report of Afghan - Lithuania Team from Ancient Sites of Ghor Province, Archaeology Institute Archive.

4- Faizi 1386 H.D (2007A.D).

Ketab Khan Faizi ,Scientific report of Bamiyan Province Ancient Sites, Afghanistan Archaeology Magazine, Third Period, Issue Fifth.

5- Scientific report 1382 H.D (2003A.D).

6- Scientific report of Afghan-Italy Team from Ancient Sites of Ghor Province. Archaeology Institute Archive. 
Khair Mohammad khairzada

\section{Archaeological excavation and Aynak copper mine}

Afghanistan located on the central Asia, often called the cross road of the civilization along the ancient silk road between china and the near east Since the early nineteenth century, Afghanistan has become known for its Buddhist sites that date back to the early centuries of the modern era. Most famous of all are, or better, were. the two giant Buddha statues in Bamiyan, which were destroyed in 2001. But all over the country, and especially in the east, Buddhist stupas and other remains still crown many hilltops.

Mes Aynak is a small valley on the righty bank of the Logar River, $30 \mathrm{~km}$ south of Kabul. it is thus close to Kabul, starting point of roads leading to Pakistan and northern India via Jalall Abad and the valley of the Kabul river, and to central Asia via Begram and the Hindukush passes. It is also on the KabulGardez- Khost road leading to northern India (today Pakistan) through north Waziristan and the Kurram Valley and close to the Ghazni - Kandahar road. ${ }^{1}$

The site, previously known from geologists reports only, was explored by the afghan institute of archaeology in 2004, rescue excavations were since undertaken, partly through a huge grant (or compensations) on the Chinese mining company as part of a contract to start there a huge copper mine the Chinese company, which mad test drills and planned to begin the extraction of the ore at the end of excavation program by ministry of information and culture in 2013. Archaeological excavation was supposed to have come to an end that date which was not possible, although the excavating are not finish yet. the chine's company wants to finish fast the excavation as soon as possible, if the Chinese company does not wants to postpone the beginning of the mine, and started, would entail the destruction of most of the uncovered buildings and sites, the scholarly were written about Mes Aynak and published In the 
Archaeological excavation and Aynak copper mine

magazines and catalogues, I also want to write about archaeological excavation and put some more lights on it

Mes Aynak is first of all a huge copper deposit, partly above the earth, the so-called Tape Baba Wali ( mountain of Baba Wali village ), $18 \mathrm{Km}$ to East of Kabul and Gardiz road, Mostly covered by later deposits. Mainly loess brought by the wind and $5 \mathrm{Km}$ to east of Logar River. Excavation was started on the mountain in March of 2011 which still continue, the top of the mountain was fortified, 2

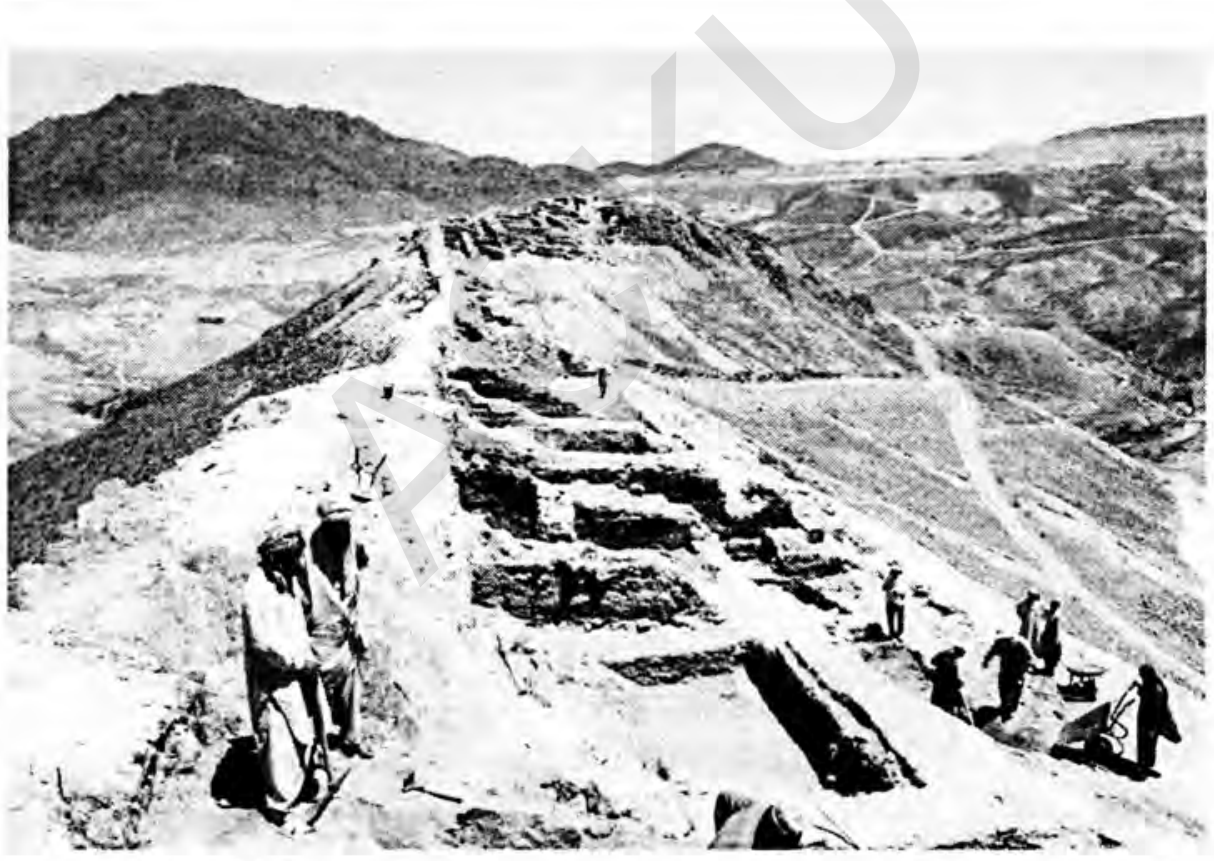

Top of the Aynak Mountain during the excavation showing to north, (c) khair mohammad khairzada, 2012 
the Mes Aynak complex entirely surrounded by fortifications and watch towers. a protection against attacks from tribes, And a way to ensure that the miners, if slaves, do not flee, there were building on the top of the mountain for some of the ore was melted there, as testified by numerous finds of slugs up to the top of the ridge. But there was at least one rich inhabitant there as testified by the discovery, of the year 2012 of a silver plate with shapur2 head. Huge mounds of slugs, Sometimes $15 \mathrm{~m}$ high, now covered by loess, have been discovered at the bottom of the ridge Local conditions made the metallurgical operations somewhat easy: high content of copper in the ore: wood in quantity since the nearby hills were covered with forests, as Paktya was not long ago: availability of water the river is dry, except for a few days in spring, but there are many springs and some qarez.

Mining in Mes Aynak was done only through tunnels in the mountain. The entrances of some were discovered no furnace has been found till now. But some remains of melting residues have been found. They will provide clues about the technique used for copper manufacturing. The copper, after being separated from the ore, was probably exported ingots. ${ }^{3}$ 
Archaeological excavation and Aynak copper mine

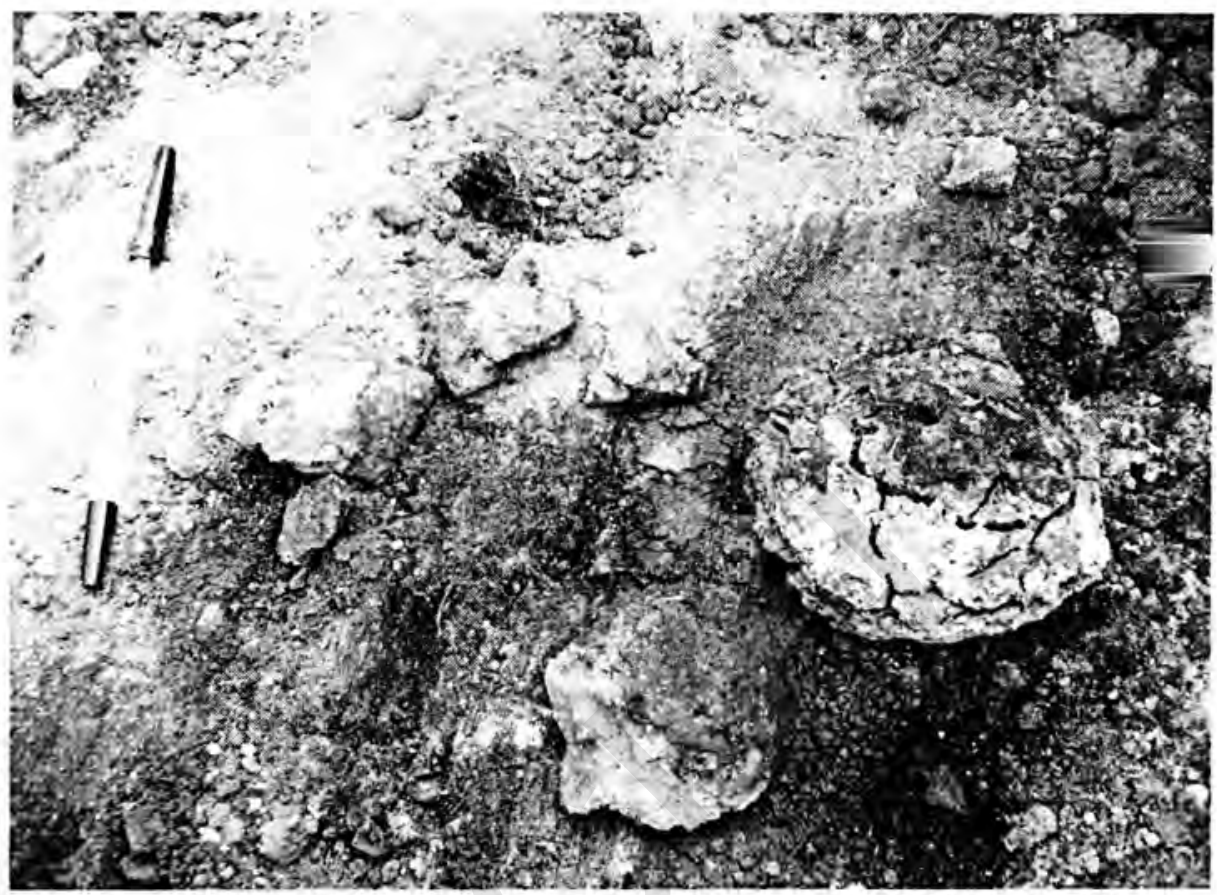

The remains of ore after melting, Mes Aynak,@khair Mohammad khairzada,2012

The exploration of the mine did not yet provide any clue for datation ; c 14 analyses are planned, specially for the stratified slag deposit which can give dates for the beginning and end of the exploration, for now, we can use the data recovered from the nearby archaeological sites. Specially the ruins of the ancient Baba Walli village, probably inhabited by the miners. the earliest shard found so far is early kushan, may be late Greek, the earliest coin found no far is a posthumous Hermaios. Pending any now discovery, we may say that work at the mine begin in the $1^{\text {st }} \mathrm{c}$. and stopped not long before the advent of the Arabs. ${ }^{4}$ 
That could explain why Wima Kadphises (c.40 - 78 or later) could adopt a heavy bronze standard and the kushans could coin millions of copper coins, replacing the former silver currency and much smaller copper coins of their predecessors. The progressive lost of weight of kushan copper coins during Huvishkas reign and later could be explained either by lack of control on the production in a fragmented empire, or by the gradual exhaustion of a mine exploited in antiquity without recourse to modern machinery and chemistry and without any possibility to clear away the loess deposits.

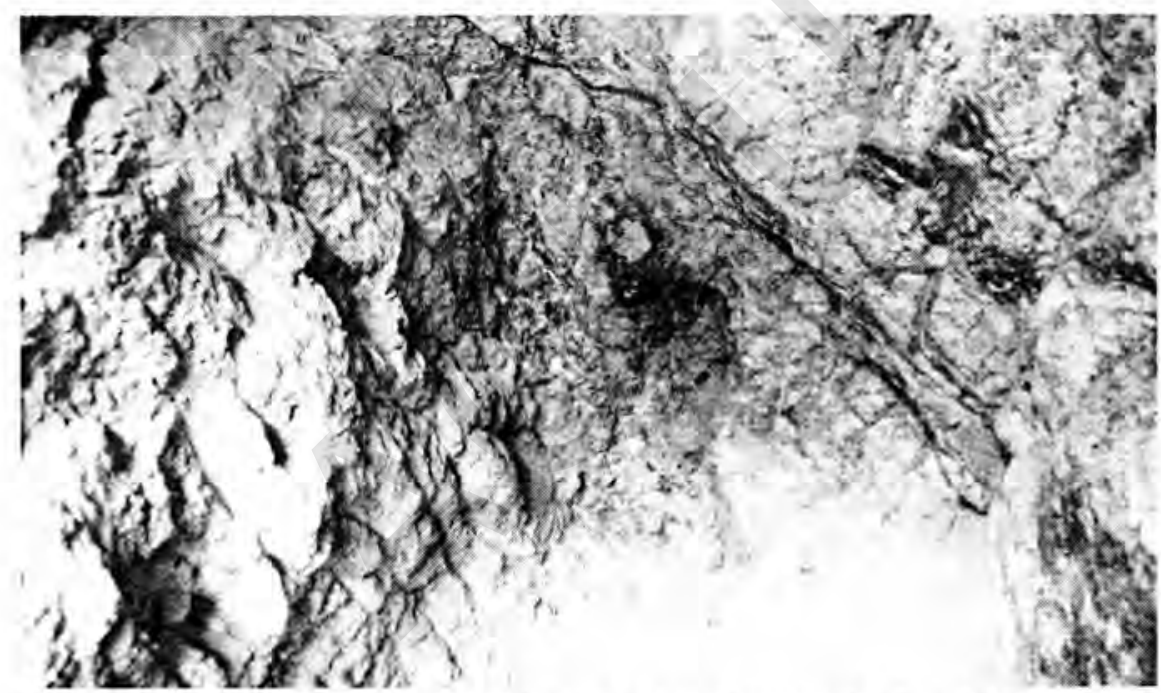

Sign of the tools, shows the extraction in ancient time on the Aynak Mountain, (c) Khair Mohammad Khairzada, 2012.

The upper layer of the Baba Walli village has been cleared almost entirely it is made of poorly constructed rooms; streets are can be seen. no great building has been discovered, although there should have been a bigger or bigger house(s) for the officials and technicians overseeing the mining, the melting of 
the ore and the expedition of the copper cakes .Interesting finds were nevertheless made 'a jeweler's hoard A unique small Gandharan Buddha with incised aureole, a broken statue of a standing Buddha 'probably an import from Gandhara, a stone relief of the Dipankarajataka, whose back is painted ( two kneeling donors under a preaching Buddha )remains of manuscripts written in Brahmi script and dating to the $4-6^{\text {th }} c A D$. The pottery recovered from the village ranges from kushan times to the $6^{\text {th }} c$. $A D$; but the lower layers have not yet been fully explored it will be excavated in future.

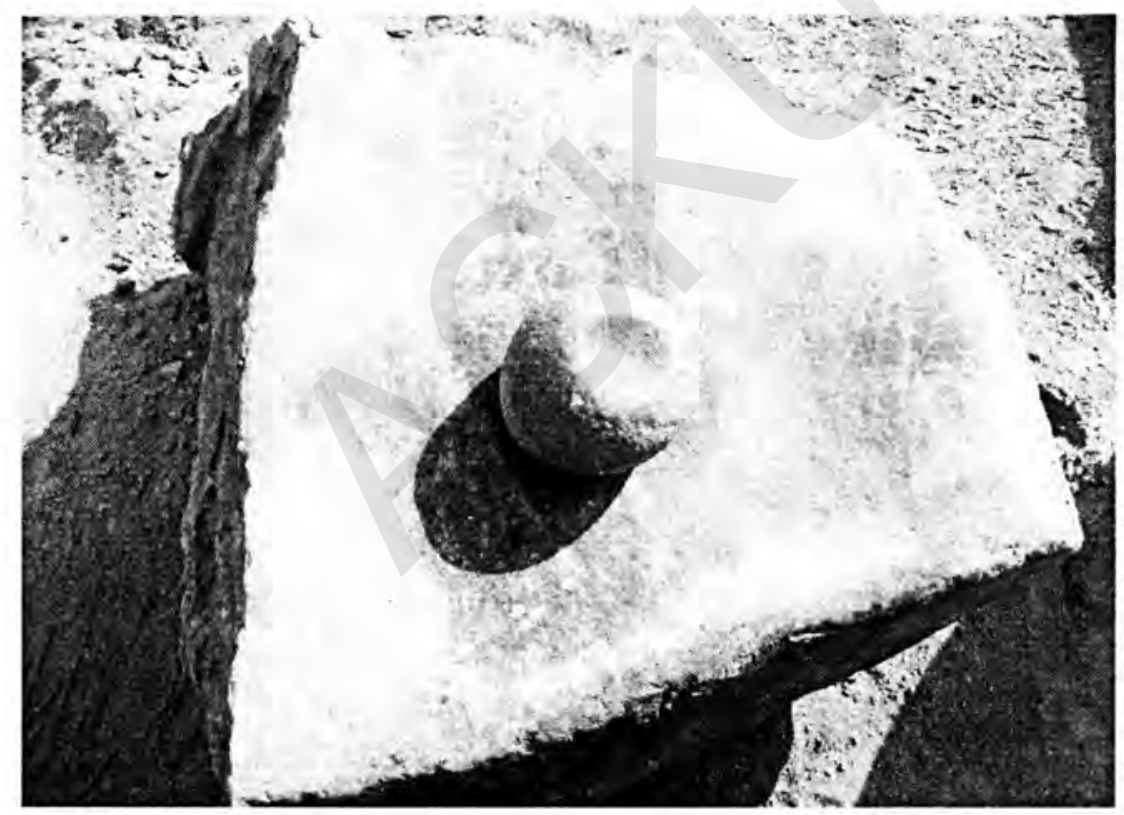

Hammer and anvil stone founded in Aynak Mountain. Image taken by Khair Mohammad Khairzada, 2012 
as conclusion archaeological excavation in Mes. Aynak have been started in 2009 and till now it is continue, most part of the site had finished or unearthed and many more archaeological site need to be excavated. as I think, according to the current situation archaeological work need more delay to bring process research to the end, because all these buildings will soon be destroyed which are still under the earth, or heavily damaged, when the heavy machinery and trucks of the mining company begging to dig into the loess in search of the copper ore lying below it.

\section{To be continue}

\section{Bibliography}

1-Khairzada Khair Mohammad, Mes Aynak, PARIS La renovation de la crypte Notre - Dame, No 508 - march 2013, page 63.

2-Faizi Ketab Khan, Mes-e-Aynak-e-Logar in the light of Archaeological Excavation, Academy of Sciences, Human Sciences Section, Archaeological Research Center,Vol,1- Febervery: 2012,page 9.

3- Azizi Nazar Mohammad, Mes Aynak, Archaeology of Afghanistan, Valum II, Peshawar 1383, page 86 .

4- Kohzad Ahmad Ali, Afghanistan Dar Partaw - e - Tarekh, Kabul 1346,page 259 


\section{Volume No 30 : (March 2016)}

Editorial:

1- Prof: Asmatullah Osmani.

2- Prof: M. Aslam afzali.

3- Prof: M. A. Rawof Zakir.

4- Prof: Nasrullah Nasir.

5- Prof: Nazar Muhammad Azizi.

6- Prof: Katab Khan Faizi.
Director: Assistant Prof: Mohammad Anwar Faiz

Deputy Director:

publisher: Archaeological Research Center.

Compose and design: Mohammad Anwar Faiz
Annual subscription:

In Afghanistan: 150 Af

Foreign countries: by air- $100 \$$

For students: 75 Af

Cost of one volume: $100 \mathrm{Af}$

$$
\begin{aligned}
& \text { اشتئر اك سالاتهه: }
\end{aligned}
$$

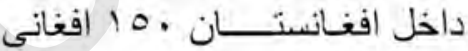

$$
\begin{aligned}
& \text { خار ج كثور . . } 1 \text { دالر امريكايى اني }
\end{aligned}
$$

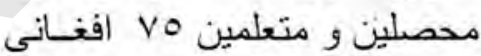

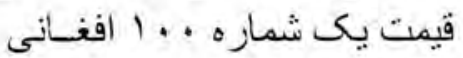

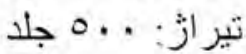

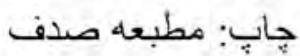

شرح بشتى صفحه دوم:. بِارجه ظروف سفالى كه بروي آن نيم رخ يك شهز اده مهر

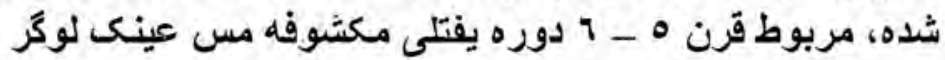

أدرس: مركز تحقيقات باستانشناسيى

قَلعه فتح الله - كابل- افغزانستان

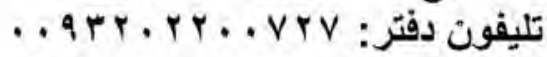


Islamic Republic of Afghanistan

\author{
Academy of sciences
}

\title{
Archaeology Research Center
}

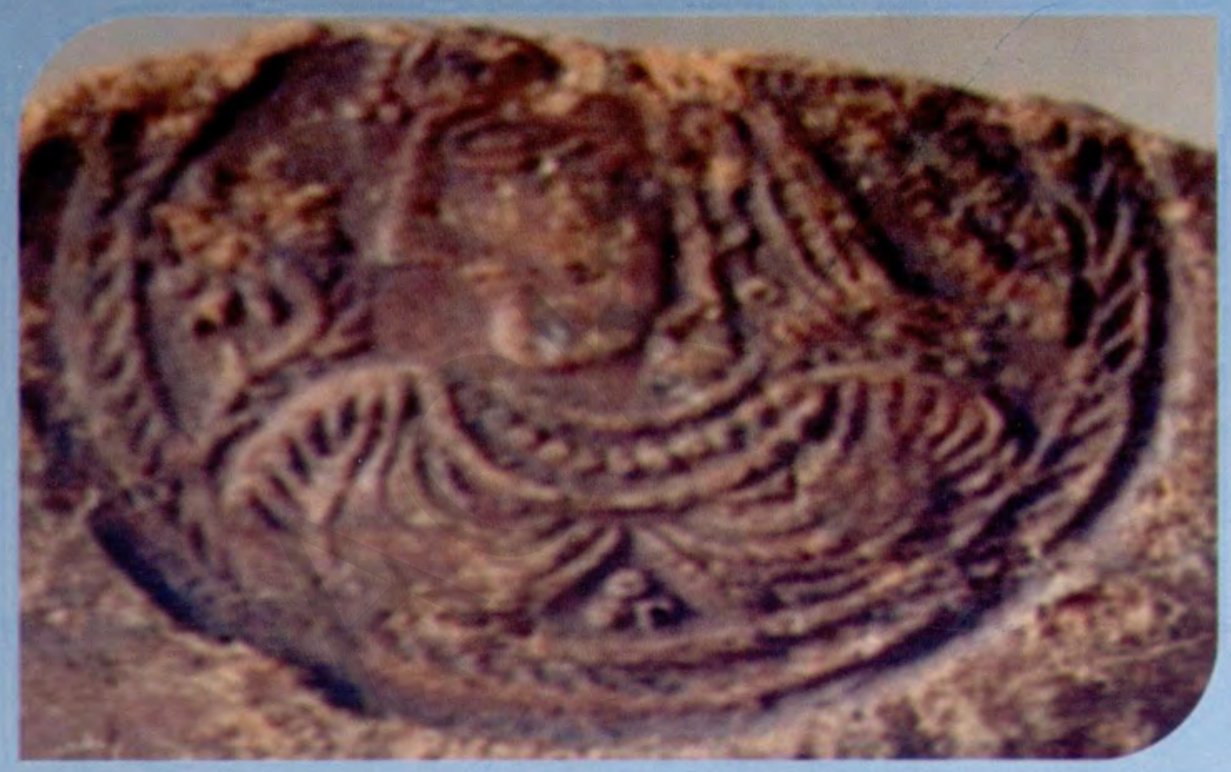

Director and editor: Assistant Prof: Mohammad Anwar Faiz. Address: Archaeological Research Center of Academy of Sciences.

Qala-i-Fathullah, Kabul

Tel: $\quad$ 0093-20 2200727 